\title{
Interim Results from a Study of the Impacts of Tin(II) Based Mercury Treatment in a Small Stream Ecosystem: Tims Branch, Savannah River Site
}

30 March 2012

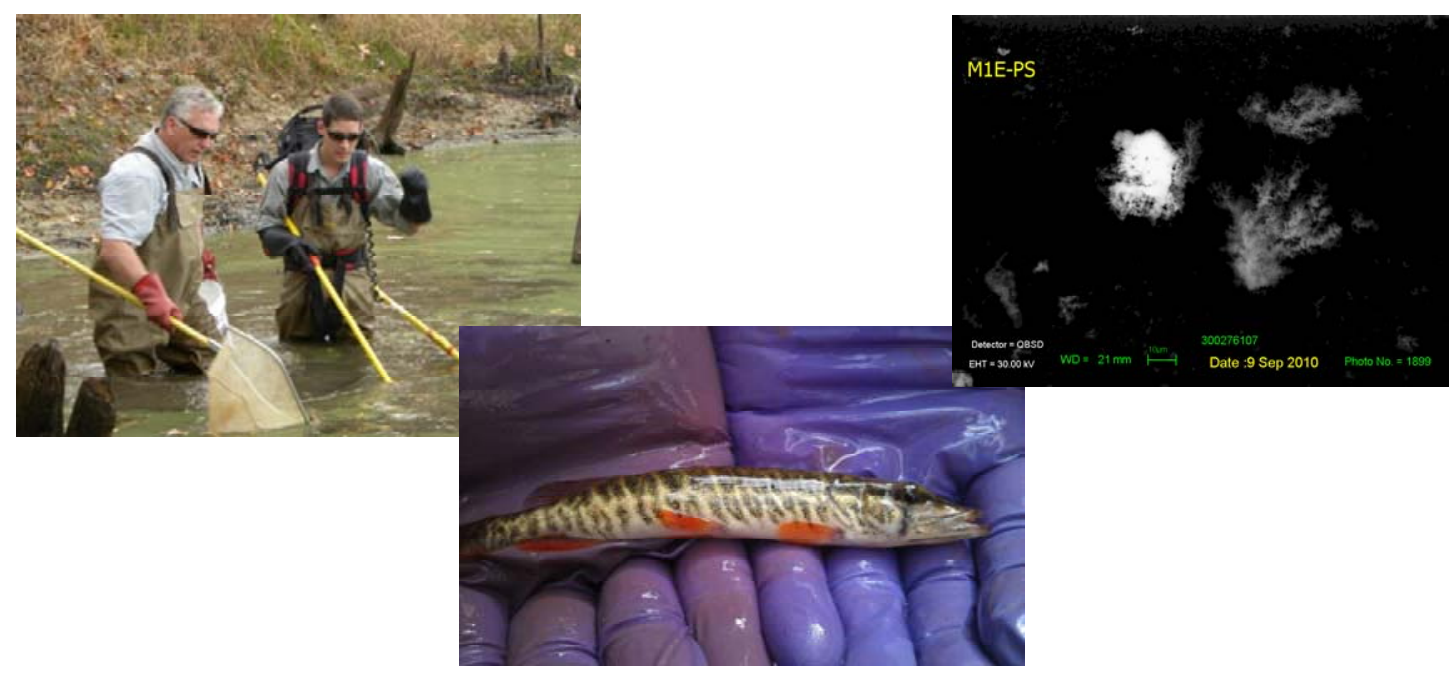

Sponsored by the U.S. Department of Energy Environmental Management Office of Site Restoration - Soil and Groundwater (EM-12)
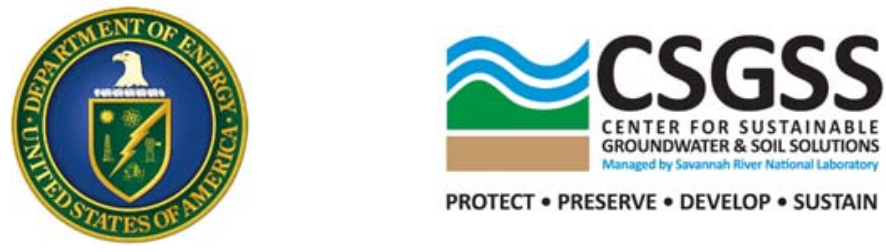

PROTECT • PRESERVE • DEVELOP • SUSTAIN

This document was prepared in conjunction with work under Contracts DE-AC09-08SR22470, DE-FC09-07SR22506, DE-AC05-00OR22725 and

DE-EM-0000598 with the U.S. Department of Energy. 


\section{Cover Photos (L to R):}

ORNL scientists (W. Kelly Roy and R. Trent Jett) collecting fish from a beaver pond using a backpack shocker; typical specimen of redfin pickerel; scanning electron micrograph of flocculated tin oxide particulate collected from treated water exiting the M1 air stripper

Participating Organizations: Savannah River National Laboratory, University of Georgia Savannah River Ecology Laboratory, Oak Ridge National Laboratory, and the Applied Research Center at Florida International University
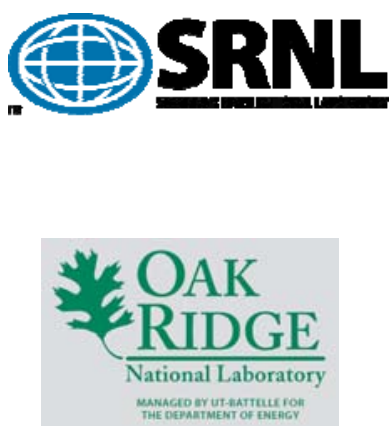
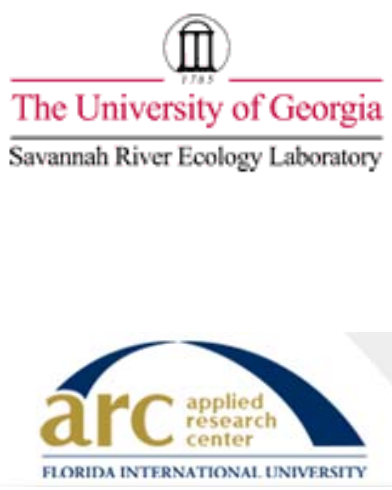

\section{Printed in the United States of America}

Prepared For

U.S. Department of Energy Office of Environmental Management Office of Site Restoration

Soil and Groundwater (EM-12)

\section{DISCLAIMER}

This work was prepared under an agreement with and funded by the U.S. Government. While the authors have taken care in the preparation of this report, neither the U. S. Government or its employees, nor any of its contractors, subcontractors or their employees, makes any express or implied: 1 . warranty or assumes any legal liability for the accuracy, completeness, or for the use or results of such use of any information, product, or process disclosed; or 2. representation that such use or results of such use would not infringe privately owned rights; or 3. endorsement or recommendation of any specifically identified commercial product, process, or service. Any views and opinions of authors expressed in this work do not necessarily state or reflect those of the United States Government, or its contractors, or subcontractors. 


\section{Interim Results from a Study of the Impacts of Tin(II) Based Mercury Treatment in a Small Stream Ecosystem: Tims Branch, Savannah River Site}

30 March 2012

Edited by:

Brian B Looney, Savannah River National Laboratory (SRNL)

A. Lawrence (Larry) Bryan, Jr., Savannah River Ecology Laboratory (SREL)

Teresa J. Mathews, Oak Ridge National Laboratory (ORNL)

Contributors:

Brian B Looney, SRNL

Larry Bryan, Jr. SREL

Teresa J. Mathews, ORNL

John G. Smith, ORNL

Mark J. Peterson, ORNL

Amaury Betancourt (Florida International University)

Dennis G. Jackson, SRNL

Margaret R. Millings, SRNL

Michael H. Paller, SRNL

David Kling, SREL

W. Kelly Roy, ORNL

R. Trent Jett, ORNL

Carrie L. Miller, ORNL

Gary L. Mills, SREL

Angela Lindell, SREL

John C. Seaman, SREL

Prepared for the U.S. Department of Energy Environmental Management Office of Site Restoration - Soil and Groundwater (EM-12), Washington DC

This document is available through the U.S. Department of Energy Office of Scientific and Technical Information (OSTI) at www.osti.gov 
\{“blank" page\} 
Interim Results from a Study of the Impacts of Tin(II) Based Mercury Treatment in a Small Stream Ecosystem: Tims Branch, Savannah River Site

Table of Contents

$\begin{array}{ll}\text { Executive Summary } & 1\end{array}$

$\begin{array}{ll}\text { Introduction } & 2\end{array}$

Purpose and Scope $\quad 2$

Objectives 3

$\begin{array}{ll}\text { Tasks } & 4\end{array}$

Report Contents and Organization 4

Background $\quad 5$

Mercury at the Savannah River Site 5

Description of Tims Branch 6

Mercury Treatment Using Tin(II) Chloride and Air Stripping 11

Uncertainties Associated with Mercury Treatment Process 13

$\begin{array}{ll}\text { Methods } & 14\end{array}$

$\begin{array}{ll}\text { Sampling Strategy and Locations } & 14\end{array}$

$\begin{array}{ll}\text { Analytical Methods and Quality Assurance } & 18\end{array}$

$\begin{array}{ll}\text { Results } & 21\end{array}$

$\begin{array}{ll}\text { Treatment Process Characterization } & 21\end{array}$

Geochemical Monitoring $\quad 25$

$\begin{array}{ll}\text { Biological Monitoring } & 29\end{array}$

$\begin{array}{ll}\text { Conclusions } & 33\end{array}$

References $\quad 34$

Appendices

A. Graph of Mercury Concentrations Entering Tims Branch 40 (with extended annotation)

B. Example Quality Assurance Information 41

C. Tabulated Information on Whole Body Fish Samples 46

for Tims Branch (2006 and 2010) 


\section{List of Figures}

1 Example baseline (1999-2001) water data for mercury in surface waters 3 and rainfall near the DOE Savannah River Site

2 Tims Branch stream system in the A/M Areas of the Savannah 5 River Site (SRS)

3 Graphical summary of the history of mercury discharges to the Tims Branch System and available environmental data

4 Mercury concentrations measured at the A01 and former A11 outfalls

5 Schematic diagrams of simple process of mercury removal by means of chemical reduction followed by stripping or sparging

6 Annotated overhead photograph of the Tims Branch system

$7 \quad$ Morphology of M Area outfall tributary and Tims Branch

8 Geochemical speciation of tin for outfall conditions

$9 \quad$ SEM images of particulates in water exiting the M1 Air Stripper

10 Elemental fingerprints for SPOT-1 (aluminosilicate) and

SPOT-2 (oxidized tin solid)

11 Water concentrations for tin in M Area outfall tributary 26 and Tims Branch

12 Sediment concentrations for tin in M Area outfall tributary 27 and Tims Branch

13 Biofilm concentrations for tin in M Area outfall tributary 28 and Tims Branch

14 Mercury concentration in redfin pickerel collected from Tims Branch $\quad 30$ ponds in 2006 and 2010 as a function of length

15 Summary of mercury concentration for nominal $150 \mathrm{~mm}$ length redfin 31 pickerel collected from Tims Branch ponds in 2006 and 2010

16 Mercury concentrations in composites of Dusky shiners collected from 32 the Tims Branch watershed and a reference site in November 2011

17 Mercury concentrations in fillets of redfin pickerel collected from the Tims Branch watershed and a reference site in November 2011

\section{List of Tables}

$1 \quad$ Sampling locations 16

2 Summary of Analytical Methods 


\section{Interim Results from a Study of the Impacts of Tin(II) Based Mercury Treatment in a Small Stream Ecosystem: Tims Branch, Savannah River Site}

\section{Executive Summary}

A research team is assessing the impacts of an innovative mercury treatment system in Tims Branch, a small southeastern stream. The treatment system, installed in 2007, reduces and removes inorganic mercury from water using tin(II) (stannous) chloride addition followed by air stripping. The system results in discharge of inorganic tin to the ecosystem. This screening study is based on historical information combined with measurements of contaminant concentrations in water, fish, sediment, biofilms and invertebrates. Initial mercury data indicate that first few years of mercury treatment resulted in a significant decrease in mercury concentration in an upper trophic level fish, redfin pickerel, at all sampling locations in the impacted reach. For example, the whole body mercury concentration in redfin pickerel collected from the most impacted pond decreased approximately 72\% between 2006 (pre-treatment) and 2010 (post-treatment). Over this same period, mercury concentrations in the fillet of redfin pickerel in this pond were estimated to have decreased from approximately $1.45 \mu \mathrm{g} / \mathrm{g}$ (wet weight basis) to $0.45 \mu \mathrm{g} / \mathrm{g}$ - a decrease from $4.8 \mathrm{x}$ to $1.5 \mathrm{x}$ the current EPA guideline concentration for mercury in fillet $(0.3 \mu \mathrm{g} / \mathrm{g})$. Thermodynamic modeling, scanning electron microscopy, and other sampling data for tin suggest that particulate tin (IV) oxides are a significant geochemical species entering the ecosystem with elevated levels of tin measured in surficial sediments and biofilms. Detectable increases in tin in sediments and biofilms extended approximately $3 \mathrm{~km}$ from the discharge location. Tin oxides are recalcitrant solids that are relatively non-toxic and resistant to dissolution. Work continues to develop and validate methods to analyze total tin in the collected biota samples.

In general, the interim results of this screening study suggest that the treatment process has performed as predicted and that the concentration of mercury in upper trophic level fish, as a surrogate for all of the underlying transport and transformation processes in a complex ecosystem, has declined as a direct result of the elimination of inorganic mercury inputs. Inorganic tin released to the ecosystem has been found in compartments where particles accumulate with notable levels measured in biofilms.

This research is a collaboration among researchers from Savannah River National Laboratory, University of Georgia Savannah River Ecology Laboratory, and Oak Ridge National Laboratory. 


\section{Introduction}

Mercury (Hg) has been identified as a "persistent, bioaccumulative and toxic" pollutant with widespread impacts throughout North America and the world (EPA. 1997a, 1997b, 1998a, 1998b, 2000). Although most of the mercury in the environment is inorganic $\mathrm{Hg}$, a small proportion of total $\mathrm{Hg}$ is transformed through the actions of aquatic microbes into methylmercury (MeHg). In contrast to virtually all other metals, MeHg biomagnifies or becomes increasingly concentrated as it is transferred through aquatic food chains so that the consumption of mercury contaminated fish is the primary route of this toxin to humans. For this reason, the ambient water quality criterion (AWQC) for mercury is based on a fish tissue endpoint rather than an aqueous $\mathrm{Hg}$ concentration, as the tissue concentration (e.g., $<0.3 \mu \mathrm{g} / \mathrm{g}$ fillet) is considered to be a more consistent indicator of exposure and risk (EPA, 2001).

Effective mercury remediation at point-source contaminated sites requires an understanding of the nature and magnitude of mercury inputs, and also knowledge of how these inputs must be controlled in order to achieve the desired reduction of mercury contamination in biota necessary for compliance with AWQC targets. One of the challenges to remediation is that mercury body burdens in fish are more closely linked to aqueous MeHg than to inorganic Hg concentrations (Sveinsdottir \& Mason 2005), but MeHg production is not easily predicted or controlled. At point-source contaminated sites, mercury methylation is not only affected by the absolute mercury load, but also by the form of mercury loaded. In addition, once MeHg is formed, the hydrology, trophic structure, and water chemistry of a given system affect how it is transformed and transferred through the food chain to fish.

Decreasing inorganic Hg concentrations and loading may often therefore be a more achievable remediation goal, but has led to mixed results in terms of responses in fish bioaccumulation. A number of source control measures have resulted in rapid responses in lake or reservoir fisheries (Joslin 1994, Turner \& Southworth 1999; Orihel et al., 2007), but examples of similar responses in Hg-contaminated stream ecosystems are less common. Recent work suggests that stream systems may actually be more susceptible to mercury bioaccumulation than lakes, highlighting the need to better understand the ecological drivers of mercury bioaccumulation in stream-dwelling fish (Chasar et al. 2009, Ward et al. 2010).

\section{Purpose and Scope}

In the present study we examine the response of fish to remedial actions in Tims Branch, a point-source contaminated stream on the Department of Energy's (DOE) Savannah River Site in Aiken, South Carolina. This second order stream received inorganic mercury inputs at its headwaters from the 1950s-2000s which contaminated the water, sediments, and biota downstream. In 2007, an innovative mercury removal system using tin (II) chloride (stannous chloride, $\mathrm{SnCl}_{2}$ ) was implemented at a pre-existing air stripper. Tin(II) reduces dissolved $\mathrm{Hg}$ (II) to $\mathrm{Hg}(0)$, which is removed by the air stripper. During this process, tin(II) is oxidized to tin (IV) which is expected to precipitate as colloidal tin(IV) oxides and hydroxides, particulate materials with relatively low toxicity (Hallas and Cooney, 1981, EPA 2002, ATSDR, 2005). 
Since implementation of tin(II) based mercury treatment, aqueous mercury concentrations entering Tims Branch from a major outfall have decreased from approximately $250 \mathrm{ng} / \mathrm{L}$ (parts per trillion) to $<10 \mathrm{ng} / \mathrm{L}$. Concurrently, total tin concentrations near the outfall increased from $<0.5 \mu \mathrm{g} / \mathrm{L}$ (parts per billion) before treatment to approximately 10-20 $\mu \mathrm{g} / \mathrm{L}$ after treatment. While tin oxides at low " $\mu \mathrm{g} / \mathrm{L}$ " concentrations are not considered to be toxic (EPA, 2002), the effects of long term ecosystem exposures (e.g., accumulation of tin in mercury-contaminated sediments) are unknown. In some settings, tin may be methylated in the environment and organic tins are more bioaccumulative and more toxic than tin oxides; further, organic tin species has been shown to enhance mercury methylation (Celo et al. 2006). Quantification of the net value of the innovative treatment process hinges on documenting the beneficial impacts of decreasing inorganic mercury load (e.g., primarily based on decreased mercury concentrations in fish) and documenting that the released tin oxides have minimal adverse impacts in terms of bioaccumulation, toxicity to benthic or lower organisms, or methylation and chemical interactions with mercury or other elements.

Tims Branch provides a unique opportunity to study complex systems science in a fullscale ecosystem that experienced a controlled step change in boundary conditions. Results from this study are not only key to evaluating the effectiveness of tin(II) based mercury treatment at the SRS site, but are also relevant to evaluating the potential of using this novel remediation technology in other mercury contaminated stream systems, such as at East Fork Poplar Creek at the Oak Ridge (see Peterson et al., 2011; Looney et al., 2008; Southworth et al. 2010, 2009, 1997, and 1996).

\section{Objectives}

The objectives of the present research are to provide an initial assessment of the net impacts of the tin(II) based mercury treatment on key biota and to document the distribution and fate of inorganic tin in this small stream ecosystem after the first several years of operating a full scale system. To support these objectives, we collected fish, sediment, water, invertebrates, and biofilm samples from Tims Branch to quantify the general behavior and accumulation patterns for mercury and tin in the ecosystem and to determine if the treatment process has resulted in:

- a measurable beneficial impact on (i.e., decrease of) mercury concentration in upper trophic level fish and other biota; this is a key environmental endpoint since reducing mercury concentration in fish is a primary regulatory driver for controlling mercury in streams.

- the potential for negative impacts associated with inorganic tin, including, biological transformation and uptake, and/or undesirable accumulation/focusing of tin to in key ecosystem compartments. 


\section{Tasks}

The overall objective of the present research is to provide an initial assessment of the impacts of releasing water from a mercury treatment system that uses tin(II) and air stripping into a small stream ecosystem. The tasks are structured to provide insights about the general behavior of tin in the system, the impact of the treatment on biota, and the potential significance of the scientific uncertainties. The three tasks are:

1. Treatment Process Characterization: Geochemical characterization of tin in the air stripper and in the air stripper effluent. The principal objective of this task is to identify/confirm the form of tin exiting the process using measurements of dissolved and particulate tin, chemical/thermodynamic modeling, and imaging and elemental analysis of solid phases.

2. Geochemical Monitoring: Measurements of concentrations of tin and mercury in water and sediments. The principal objectives of this task focus on tin fate and distribution in the receiving stream system and whether tin is accumulating or focusing into key ecosystem compartments.

3. Biological Monitoring: Measurement of mercury and tin in fish and other biota in archived samples from Tims Branch prior to tin(II) based mercury treatment (2006) and post-treatment (2010-2011). The initial objective of this task is to resolve whether the impacts of the treatment are measurable in a key ecological compartment and regulatory endpoint (fish tissue). If differences are observed, these will provide relatively definitive information about the benefit of lowering mercury inputs and the potential significance of the hypothesized adverse collateral impacts (tin methylation and tin mediated mercury methylation). Sampling plans were designed to be comparable to the 2006 baseline study for whole body (w.b.) fish, and to assess spatial gradients in tin and mercury exposure and bioaccumulation in invertebrate fish tissues (fillet, digestive tract, gills, etc.).

\section{Report Contents and Organization}

This mid-project report provides a summary of the status and initial results from our work. The sections below provide background information for Tims Branch and the subject mercury treatment process, describe the various research tasks/methods, and present interim results and conclusions of the research team. 


\section{Background}

\section{Mercury at the Savannah River Site (SRS)}

Halverson et al. (2008) characterized mercury contamination in the vicinity of SRS, including detailed assessments of water, biota and atmospheric deposition. Figure 1 shows aqueous mercury concentrations both onsite and in the Savannah River (19992001). As shown, surface water has generally lower total mercury concentration and higher methyl mercury concentration than rainfall. Further, onsite "small" streams and tributaries (such as Tims Branch) and swamps which would tend to have more "wetland" and "Beaver Pond" influences, exhibit a higher methyl mercury fraction than the Savannah River. Halverson also documented that these environments with elevated methyl mercury exhibited higher mercury concentrations in fish and clams. Their findings are qualitatively and quantitatively consistent with other researchers (e.g., Mason et al., 2000; Brigham et al., 2009; Roy et al. 2009a and 2009b; Krabbenhoft, 1999; Driscoll, 1998) who document that wetlands and beaver ponds increase mercury methylation.

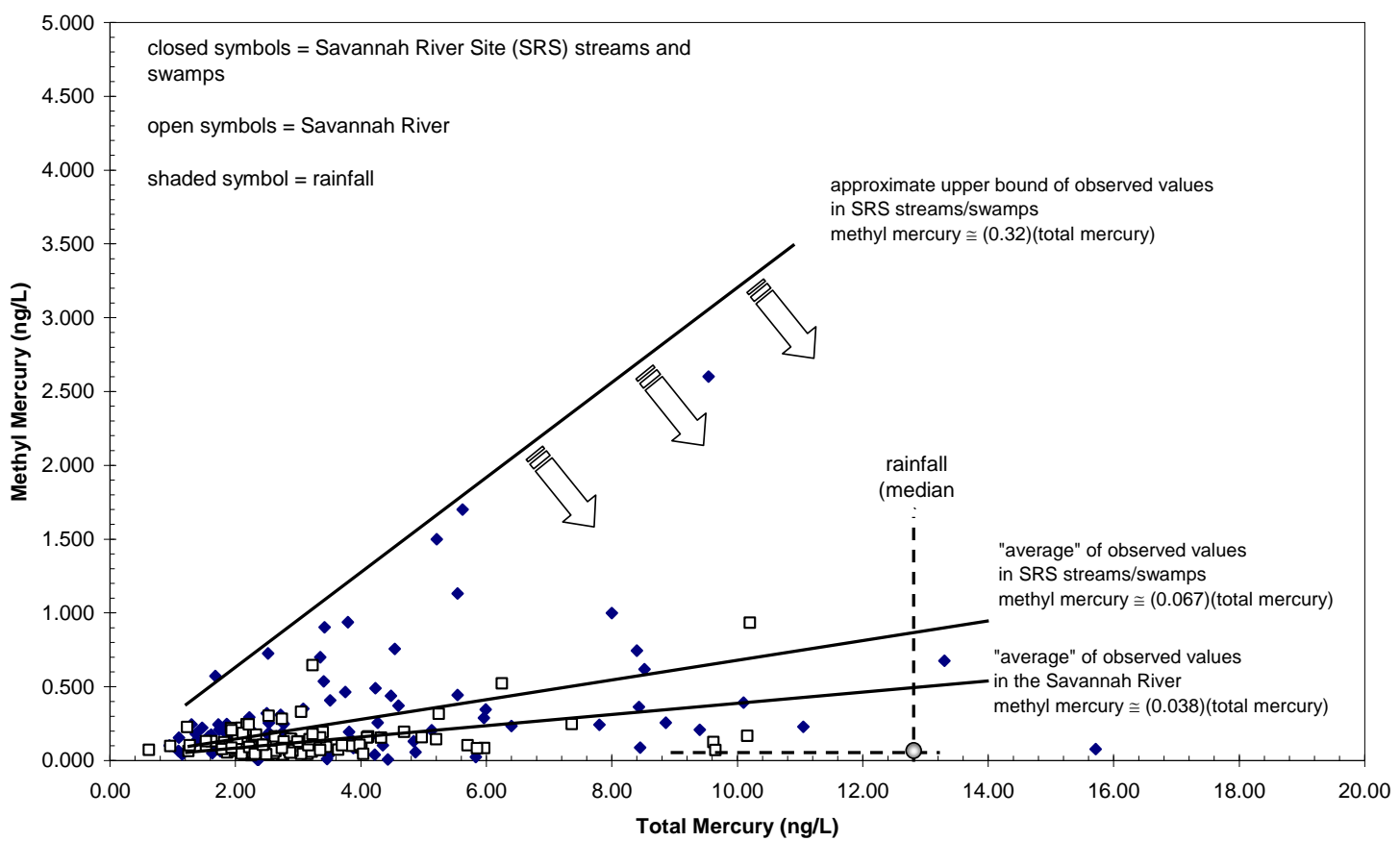

Figure 1. Baseline (1999-2001) mercury concentrations in surface waters and rainfall near the DOE Savannah River Site

The various solid lines indicate the relationship between methyl and total mercury for (from bottom to top) the Savannah River (median), on site streams (median) and on site stream (upper bound of the data). The

dashed lines indicate median rainfall from the National Atmospheric Mercury Deposition Program collection station located at the Savannah River Site. All data from Halverson et al., 2008. 
Halverson et al. (2008) provide the data to support a mass balance model for the land area of the $800 \mathrm{sq} \mathrm{km}$ SRS reservation. Mercury inputs totaled approximately $17.3 \mathrm{~kg} / \mathrm{yr}$ and consisted of: influent from Upper Three Runs (0.1 kg/yr), mercury added by SRS operations via the NPDES outfalls $(0.2 \mathrm{~kg} / \mathrm{yr})$, and atmospheric deposition (10 kg/yr wet and $7 \mathrm{~kg} / \mathrm{yr}$ dry). Mercury outputs consisted primarily of effluents via multiple site streams $(1.1 \mathrm{~kg} / \mathrm{yr})$. Assuming an approximate mass balance, the sum of the mercury storage and re-volatilization within the SRS boundary was approximately $16.2 \mathrm{~kg} / \mathrm{yr}$. Thus, greater than $90 \%$ of the mercury input is being retained in the soil, sediments, water bodies and vegetation, and/or is being reemitted to the atmosphere. Mercury released through the SRS outfalls was equivalent to approximately $1 \%$ of the total atmospheric deposition on the SRS, indicating that atmospheric deposition is the major source of mercury to the SRS environment. These findings are similar to many other studies (Lindberg et al. 2002, Ericksen and Gustin 2004, Ericksen et al. 2002, Hintelmann et al 2002, Landis and Keeler 2002), which found that, for a variety of settings, a significant fraction of mercury is atmospherically deposited and that these mercury inputs are often bound to soil and vegetation. In general, the baseline mercury characterization (Halverson et al., 2008) documented that SRS is a typical coastal plain site and that mercury entering the site's water sheds and ecosystems is subject to transport and transformation processes that are analogous to other sites in the southeast.

\section{Description of Tims Branch}

As shown in Figure 2, Tims Branch is located in the A/M Areas of the Department of Energy Savannah River Site (SRS). SRS is underlain by the layered and interbedded geology of the Southeastern Coastal Plain. Tims Branch is a second-order stream system flowing into Upper Three Runs, a tributary of the Savannah River. The headwaters of Tims Branch originate from facility outfalls in two areas - the Savannah River National Laboratory (formerly the Savannah River Laboratory) to the north and the fuel and target manufacturing facility ("M Area") to the west. In the headwater areas, the Tims Branch system is a "losing stream" (its base is above the water table and water seeps into the ground). As Tims Branch flows toward the confluence with Upper Three Runs, the stream elevation intersects the groundwater and it transitions to a "gaining stream" (water flows into the stream from the groundwater). Key morphological features relevant to potential studies in this stream include: 1) a rip-rap stabilized streambed "drop” followed by a catch basin, drain and overflow weir in the M Area outfall tributary (“outfall ditch”), 2) Steed's Pond (a former farm pond located approximately midway along Tims Branch which served as a sediment trap in the past but the dam is no longer present), and 3) several "beaver" dams and associated pools.
Key Points:

Tims Branch is a small stream ecosystem. Since 2007, Tims Branch received water from a treatment process that uses tin(II) and air stripping to reduce and remove mercury. The treated water has lower mercury concentration than pretreatment levels and contains oxidized inorganic tin. Tims Branch is a typical Southeastern Coastal Plain stream that should provide useful information about the general behaviors of mercury and tin in similar ecosystems where tin(II) chloride - air stripping treatment is being considered. 


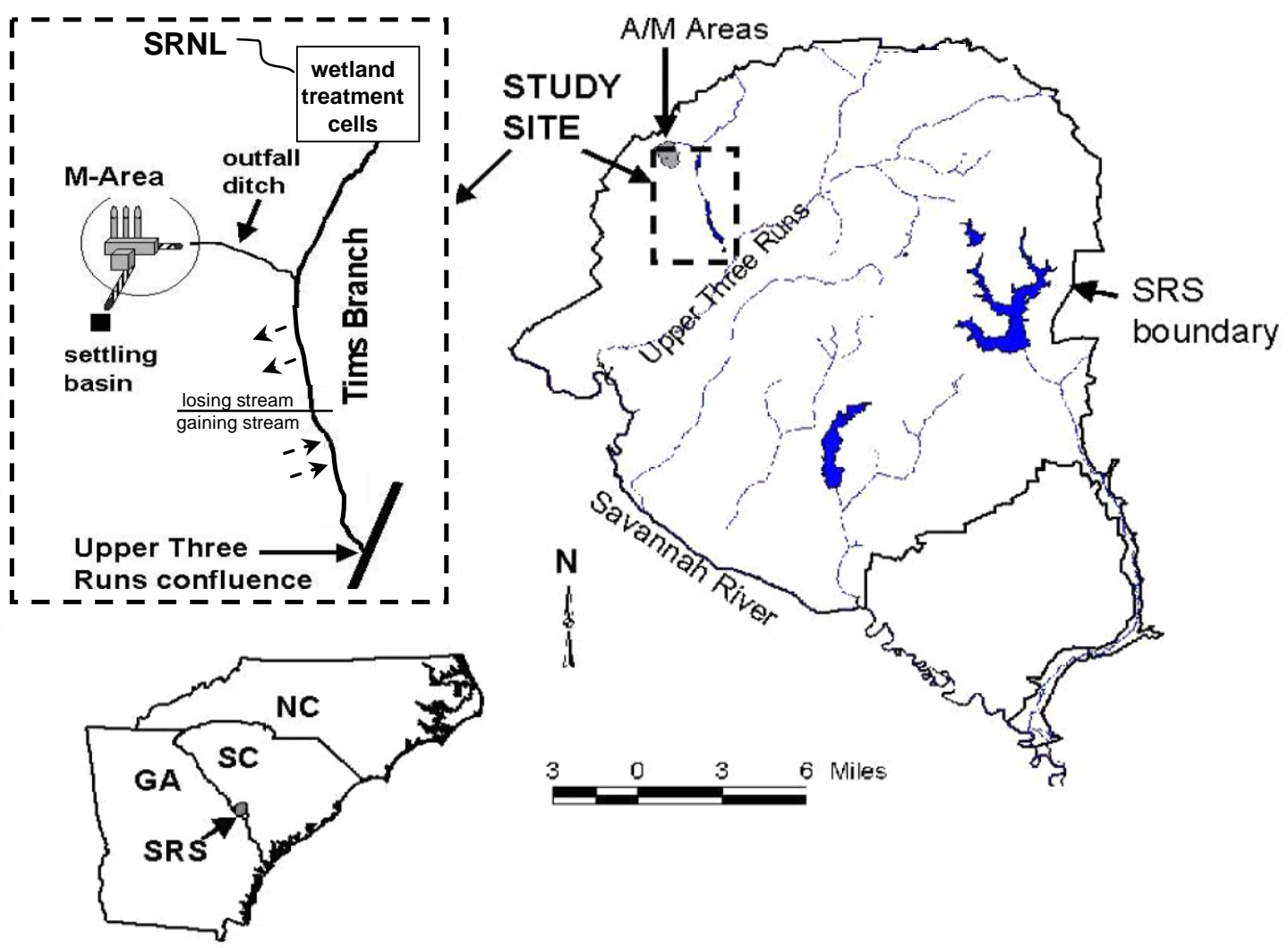

Figure 2. Tims Branch stream system in the A/M Areas of the Savannah River Site (SRS)

Discharge of process wastewater from M Area and SRNL resulted in contamination of the Tims Branch riparian ecosystem. Early M Area operations (1950s) discharged highstrength process wastes (such as aluminum forming and metal plating wastewater and spent solvents), directly into the headwaters of the outfall tributary shown in Figure 1. Later M-Area operations discharged the most contaminated wastewater to the M-Area settling basin and sent less concentrated waste streams to the outfall. All M-Area process waste discharges into the Tim's Branch system ceased in 1982 and subsequent discharges to the outfall primarily contain noncontact cooling water, treated groundwater, and facility runoff. SRNL/SREL discharged dilute laboratory and facility wastewater and runoff to the Tims Branch system in the northern headwaters beginning in the 1950s. In 2001, a wetland treatment system was installed (Figure 2) to mitigate the impacts of SRNL/SREL discharges and to lower the concentration of several metals in the stream system. The performance of the wetland treatment and its potential impact on baseline data for the proposed mercury study are discussed below. 
Tims Branch has been the subject of a large number of ecological and geochemical research studies (Looney et al., 2003b and 2010). Of these studies, the following datasets provide the most relevant baseline data to assess the impacts, or lack of impacts, of receiving large scale input of water that has been treated to remove mercury using tin(II) chloride addition and air stripping.

- Data on mercury concentrations in Tims Branch fish collected by the SREL for basic science and for EM operations - these data were collected at various times and are archived in SRS and SREL environmental databases. The most important Tims Branch archival data are from 2006. This sampling occurred approximately 5 years after the installation of the wetland treatment system in the northern headwaters (allowing a period of equilibration to the altered inputs) and approximately one year before the startup of the tin(II) chloride treatment process.

- Data on total and methyl mercury in water - these data were collected at various times -- in this case the most important data were collected as part of a sitewide special study between 1999 and 2001 (Halverson et al. 2008).

- Data on metals concentrations in Tims Branch sediments - these data were collected at various times (e.g., Pickett, 1990).

Key Points:

To address key applied science needs, the principal tasks of our research focus on generating a post-exposure datasets that are roughly equivalent (correlatable) to the pre-exposure datasets and that directly support testing hypotheses about potential impacts of lower mercury inputs and higher inorganic tin inputs on the ecosystem.

Figure 3 graphically summarizes the historical events related to mercury inputs from northern headwaters (SRNL/SREL) and the M Area outfall tributary and the available environmental data/samples from the Tims Branch system. A few key dates and events are highlighted on this figure including:

- Start-up of the M1 air stripper in 1985 (discharging to the M Area outfall tributary) and the A1 air stripper in 1993 (discharging to the northern headwaters) to remove chlorinated solvents from contaminated groundwater. Jackson et al. (2008) documented that low levels of mercury are mobilized and/or solubilized by chlorinated solvents and that the mercury reaching the stripper in contaminated groundwater is ionic and inorganic and is not strippable without being chemically reduced to elemental mercury. As a result, these two full scale groundwater remediation systems have been a predominant and steady source of inorganic mercury to both the M-Area outfall tributary and to the northern headwaters since their respective startup dates.

- Startup of the wetland treatment in the northern tributary (2001) and the tin(II) chloride addition to the air stripper for the M Area outfall tributary (2007). Both of these systems have effectively removed mercury from the two discharges since their respective startup dates. 


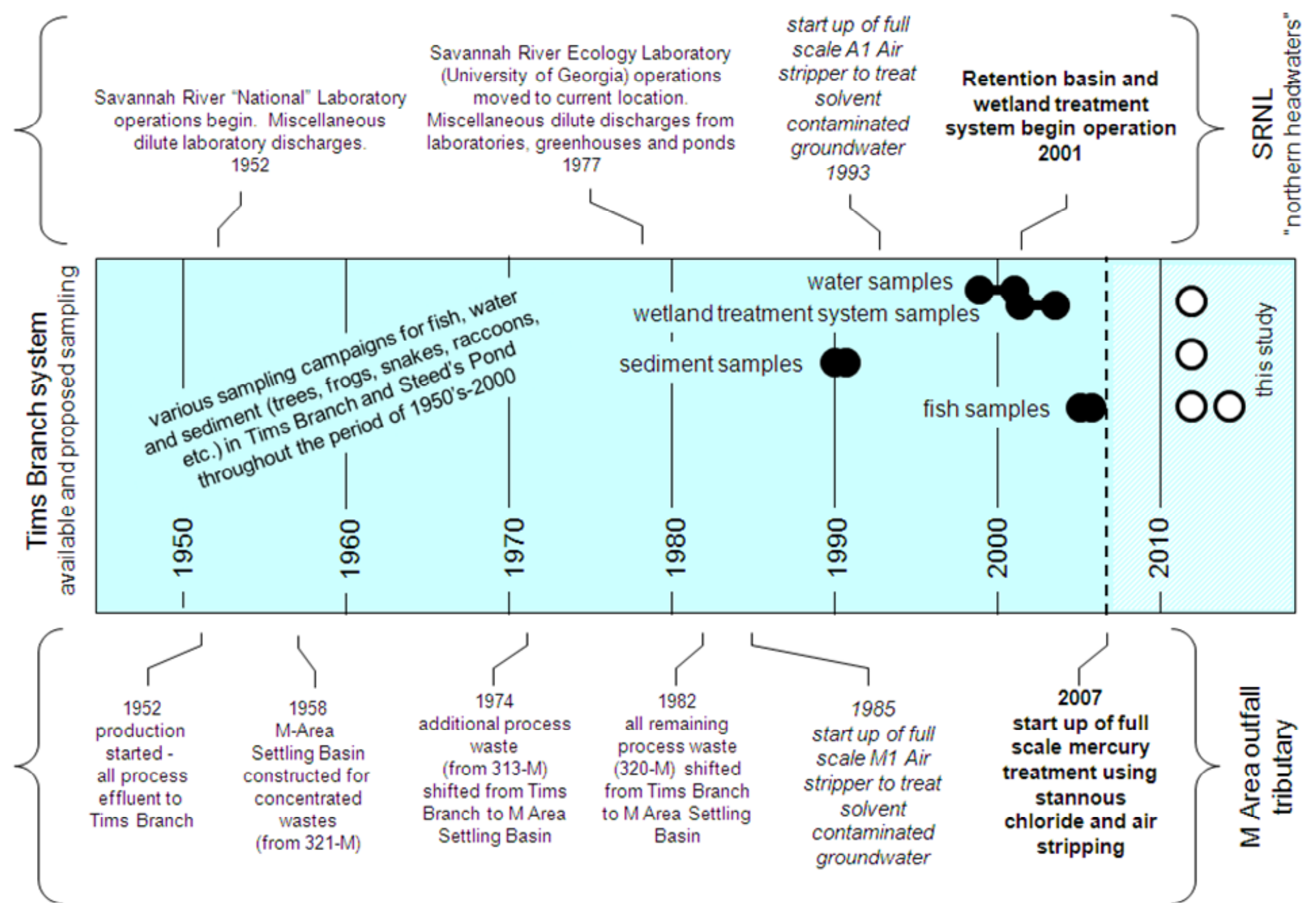

Figure 3. Graphical summary of the history of mercury discharges to the Tims Branch System and available environmental data. 
Figure 4 provides specific and quantitative information about the recent releases of mercury to the Tims Branch system. The data shown are for two key sampling locations, the A01 Outfall in the north and the former A11 Outfall located along the M Area Outfall tributary near the confluence with the main channel of Tims Branch. The A01 outfall represents the major source of water to the northern reach of Tims Branch. The former A11 outfall is a composite of several upstream outfalls that feed in to the M Area outfall tributary and includes the discharge from the groundwater treatment system (i.e., the A014 outfall with mercury concentrations approximately $250 \mathrm{ng} / \mathrm{L}$ or greater prior to November 2007). Note that the concentration of mercury in both the A01 and former A11outfalls were typically below the nominal method detection limits (approximately 100 to $200 \mathrm{ng} / \mathrm{L}$ ) provided by available techniques until the late 1990s when high sensitivity methods such as EPA Method 1631 (EPA, 1999) were developed. Thus, the detailed data in Figure 3 cover the period from 1999 through 2011. Since the primary sources of mercury to both areas of Tims Branch were discharges from stable and continuously operating groundwater remediation systems, the pretreatment information can be assumed to be generally representative of a longer period of time, however. The data suggest that pretreatment mercury concentrations in the range of 50 to $100 \mathrm{ng} / \mathrm{L}$ were typical for the A01 outfall back to 1993 and mercury concentrations in the range of 15 to $50 \mathrm{ng} / \mathrm{L}$ were typical for the former A11 outfall back to 1985 .

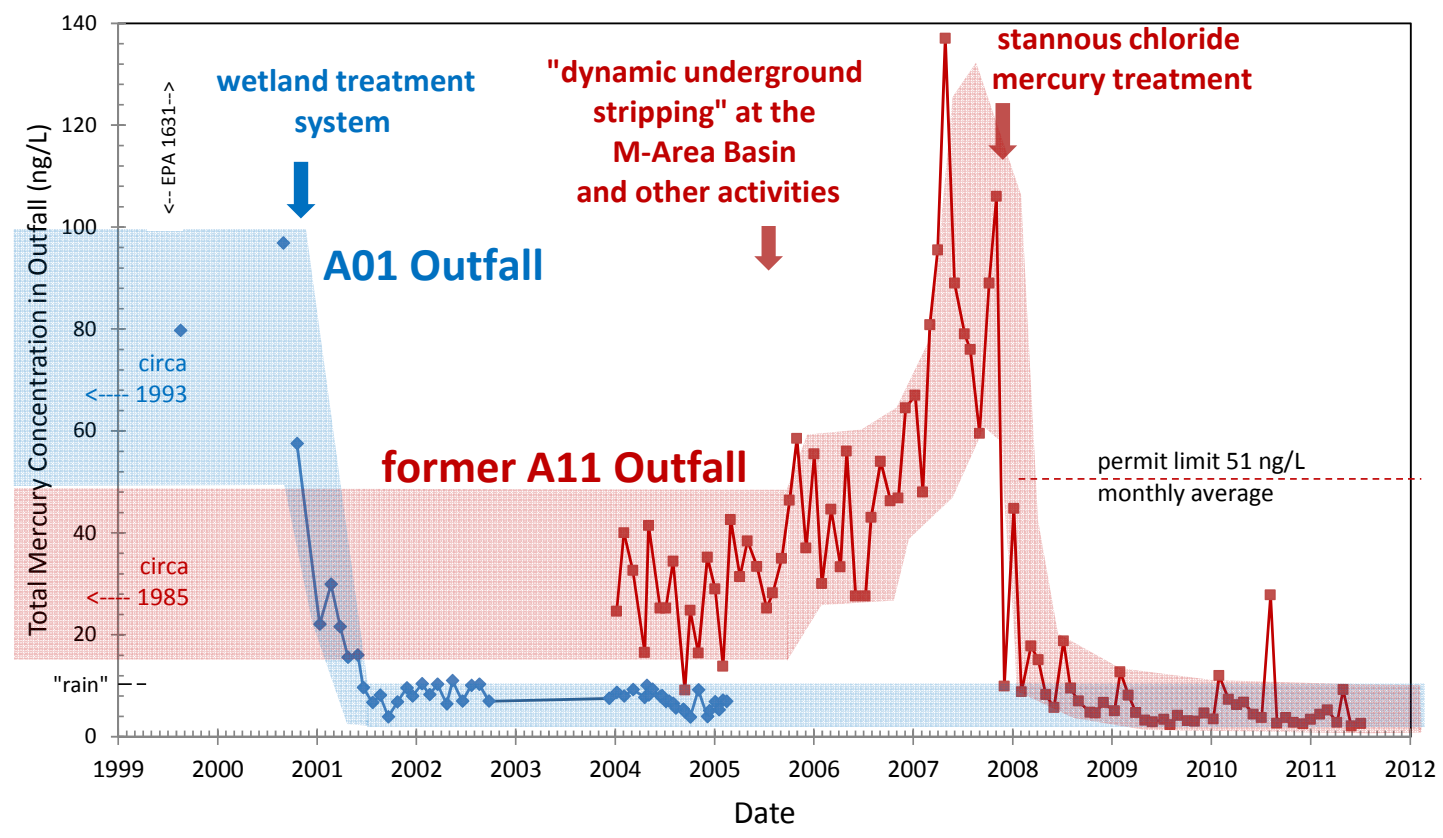

Figure 4. Mercury concentrations measured at the A01 and former A11 outfalls.

The most significant feature depicted in Figure 4 is the impact of the two major treatment actions, a wetland treatment system for the A01 outfall (Nelson and Gladden, 2007) and the tin(II) chloride air stripping system for former A11 outfall (Jackson et al., 2008). These treatment systems lowered mercury to concentrations below approximately 10 $\mathrm{ng} / \mathrm{L}$ (to concentrations that are similar to median rainfall measured at the SRS mercury deposition network sampling station (Halverson et al., 2008)), substantively eliminating direct anthropogenic inputs of mercury to the Tim Branch ecosystem. The NPDES (National Pollution Discharge Elimination System) permit limit, $51 \mathrm{ng} / \mathrm{L}$ (monthly average), for the former A11 outfall is depicted as a dashed line beginning in December of 2007. 
A second key feature depicted in Figure 4 is the observed increase in mercury concentration at the former A11 outfall between 2005 and 2007. This increase is primarily due to a supplemental groundwater treatment activity, Dynamic Underground Stripping (DUS). DUS is a thermal/steam remediation that was performed beneath the former M Area Settling Basin and was initiated in 2005. The DUS process volatilized and removed chlorinated solvents and co-contaminants, such as mercury, from the subsurface and increased the mercury concentration in batches of water that were sent to the air stripper for treatment. The pattern of peaks and valleys in the mercury measurements at the former A11 outfall closely track the pattern of mercury concentration in water being transferred from the DUS system (Appendix A). After initiation of the tin(II) chloride treatment system in November 2007, the concentrations of mercury in the DUS water sent to the stripper (which generally increased between 2007 and 2011) do not impact Tims Branch because the mercury was removed in the air stripper. Because of DUS activities, the concentrations of total mercury in the M Area outfall in mid-2006 were significantly lower than the concentrations in late 2007 when the mercury treatment process was implemented. Since the "pretreatment" fish collection was performed in the summer of 2006, the lower 2006 water concentrations are most representative and most useful for interpreting the relative mercury reduction factors for water and fish.

\section{Mercury Treatment Using Tin(II) Chloride and Air Stripping}

Treating low level mercury contaminated water using tin(II) (stannous) chloride and air stripping is a straightforward extension of the chemistry embodied in many analytical methods for mercury (e.g., Hatch 1968; EPA 1999). In these methods, tin(II) chloride is used to reduce inorganic $\mathrm{Hg}(\mathrm{II})$ to elemental mercury $(\mathrm{Hg}(0))$, which is volatile and can be removed from water by air-water contact. The volatile $\mathrm{Hg}(0)$ is then purged into a detector for analysis. In the lab, a small sparge apparatus is used to strip the mercury. For full-scale treatment, air stripping, water spraying, or sparging are examples of inexpensive air-water contactors for the mercury removal step. Figure 5 is a schematic diagram depicting the simple laboratory and full-scale concept.

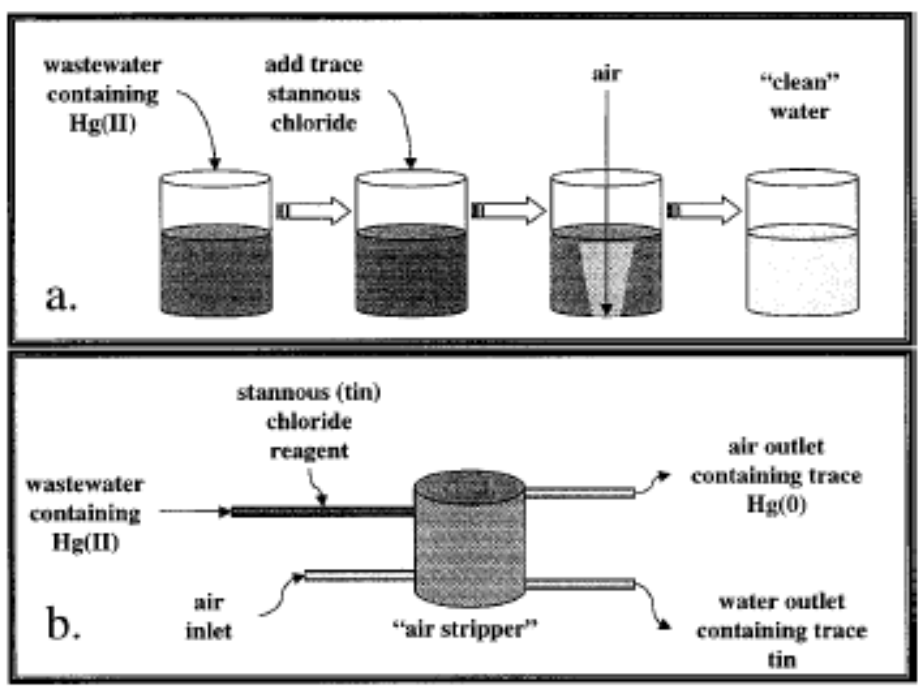

Figure 5. Schematic diagrams of simple process of mercury removal by means of chemical reduction followed by stripping or sparging

in: (a) laboratory and (b) example full-scale system 
Based on the most probable (thermodynamically favored) species in typical outfall and stream water, the overall reaction between $\operatorname{tin}(\mathrm{II})$ chloride and $\mathrm{Hg}(\mathrm{II})$ is as follows:.

$$
\mathrm{HgCl}_{2}^{0}+\mathrm{Sn}^{+2}+2 \mathrm{H}_{2} \mathrm{O} \rightarrow \mathrm{Hg}(0)+2 \mathrm{Cl}^{-}+\mathrm{SnO}_{2}(\mathrm{~s})+4 \mathrm{H}^{+}
$$

Note that the oxidized tin is predicted to form a relatively stable solid - either the tin(IV) oxide, $\mathrm{SnO}_{2}(\mathrm{~s})$, or hydroxide, $\mathrm{Sn}(\mathrm{OH})_{4}(\mathrm{~s})$. Tin in these solid forms would tend to be less available to aquatic biota and less subject to biological transformation (e.g., methylation) than dissolved forms of tin (Hallas and Cooney, 1981).

When used in analytical methods, the reaction of tin and inorganic mercury is rapid and thermodynamically favored. However, tin-based analytical methods rely on using large excesses of tin(II) chloride reagent to assure that the reaction is complete. Such high reagent concentrations are incompatible with practical and prudent implementation of this process for large volume water treatment. Research by Southworth et al. $(1996,2009$, 2010) suggested that low tin doses (5 to 10 times stoichiometry) converted available inorganic mercury to $\mathrm{Hg}(0)$ and that the mercury could be sparged. Looney et al. (2003a) and Jackson et al. (2008) generated similar results for groundwater with starting mercury concentrations ranging from approximately 150 to $250 \mathrm{ng} / \mathrm{L}$ and a treated water mercury concentration $<10 \mathrm{ng} / \mathrm{L}$. The data from the various studies indicated that the mercury-tin redox reaction is insensitive to the presence of dissolved oxygen but is sensitive to the presence of strong oxidants such as disinfectants (e.g., chlorine or bromine based biocides). The data also indicated that the mercury-tin redox reaction is relatively specific for $\mathrm{Hg}(\mathrm{II})$ and its labile complexes, that the strippability of the resulting $\mathrm{Hg}(0)$ is predictable, and that required air-water ratios are favorable (e.g., industry standard air stripper systems with air water ratios of 20 to 30 provide a high level of removal). Tinbased chemical reduction and stripping will not remove recalcitrant mercury species such a covalently bonded organic forms of mercury (e.g., methyl mercury), however, and may not effectively remove strongly bound complexes or particulate mercury.

In general, the results of the early studies suggested that effective treatment of mercury is feasible under appropriate conditions (EPA, 2007) using inorganic tin doses that are within safe levels for both ecological and human health (EPA 2002, ATSDR, 2005). Based on these results, a full scale system was implemented to treat low levels of mercury co-contamination present in solvent contaminated groundwater at the Savannah River Site (Jackson et al. (2008)). In this system, tin(II) chloride is added to the groundwater prior treatment in the M1 air stripper. The treated effluent from this system is released to the headwaters of a tributary to Tims Branch. The M1 air-stripper system has operated since 1985 to treat groundwater containing chlorinated solvent, primarily tetrachloroethene (PCE) and trichloroethene (TCE). The groundwater treatment system consists of a series of groundwater recovery wells and the air-stripper that operates at a nominal $1.74 \mathrm{~m}^{3} / \mathrm{min}(460 \mathrm{gpm})$.

Supplemental full-scale mercury treatment was started in November 2007. Initial capital costs for the supplemental equipment needed for mercury removal using the existing air stripper were low (e.g., \$10000) and the increase in operating costs is less than $\$ 0.05$ per $\mathrm{m}^{3}$. Since startup of the mercury treatment, tin concentration in the treated water exiting 
SRNL-STI-2012-00202

Page 13 of 64

the M1 stripper has ranged from 10 to $20 \mu \mathrm{g} / \mathrm{L}$. Thus, the nominal annual loading of tin to Tims Branch has been approximately $15 \mathrm{~kg}$ per year during this period.

\section{Uncertainties Associated with Mercury Treatment Process}

Three main scientific issues/uncertainties have been identified related to long term full scale application of mercury treatment using tin(II) chloride and air stripping. All of these manifest in potential stream impacts: 1) tin methylation - resulting in potential for tin uptake in biota and associated impacts, 2) tin mediated mercury methylation - linked with the first issue, resulting in a potential to increase mercury methylation due to direct abiotic reaction of methyl tin with inorganic mercury species, and 3) accumulation of tin in sediments and other ecosystem compartments where particulates accumulate or are taken up. These issues/uncertainties are briefly described below.

1. Tin is subject to microbial methylation in both aerobic and anaerobic sediments and methyltin compounds have been detected in both fresh and salt water (Ridley et al. 1977, Braman and Tompkins 1979, Gilmour et al. 1985, Chen et al. 2007, Jackson et al. 1982, Craig and Rapsomanikis 1985, Amouroux et al. 2000, Rapsomanikis and Weber 1985, and others). While the fraction of tin that was observed to be methylated by natural processes in many environments was relatively low and the conditions that maximize methylation (e.g., high salinity) are not present in typical freshwater streams, the potential exists for tin methylation in freshwater stream and riparian systems receiving long term discharges from outfalls being treated using tin(II) chloride and air stripping.

2. Abiotic methylation of dissolved Hg (II) by methyltin species was investigated in a series of detailed kinetic studies by Celo et al. 2006. They found monomethyltin to be the most effective reactant, and measured reaction kinetics at $20^{\circ} \mathrm{C}$ using $0.02 \mathrm{mM}(4,000,000 \mathrm{ng} / \mathrm{L}) \mathrm{Hg}(\mathrm{II})$ and $0.2 \mathrm{mM}$ monomethyltin $(24,000 \mu \mathrm{g} / \mathrm{L}$ as $\mathrm{Sn}$ ). The reaction was found to be sensitive to $\mathrm{pH}$ (increasing with increasing $\mathrm{pH}$ ) and chloride (increasing with increasing chloride). Celo et al. (2006) then used the kinetic data from their study to estimate how fast the reaction of monomethyltin with $\mathrm{Hg}$ (II) would proceed in seawater at $\mathrm{pH} 8,20^{\circ} \mathrm{C}$ using $1.2 \mu \mathrm{g} \mathrm{Sn} / \mathrm{L}$ as the concentration of monomethyltin and $1 \mathrm{ng} / \mathrm{L}$ as the concentration of dissolved $\mathrm{Hg}(\mathrm{II})$. They estimated a reaction half-life under these conditions of 4.5 years. Based on the literature, the reaction in lower $\mathrm{pH}$ freshwater systems would be significantly slower.

3. Accumulation of tin in a small-stream ecosystem sediments and other compartments has the potential to impact the local microbiology and the macrofauna. Hallas and Cooney (1981) showed that high levels of tin (IV) added to Chesapeake Bay sediment and various culture media decreased the viability of natural microbial populations. Importantly, they also demonstrated that tin (IV) toxicity "depends more on chemical species than on the metal concentration in the medium" and that tin (IV) that precipitated "did not participate in the metal's toxicity." Thus, the potential impacts of tin accumulation hinge on the nature of the ecosystem compartment, the amount of tin that builds up under representative conditions, and the chemical form of this tin (e.g., whether it is primarily present as a "non-participating” oxide/hydroxide precipitate). 


\section{Methods}

\section{Sampling Strategy and Locations}

Figure 6 is an annotated overhead photograph that shows a plan view of the Tims Branch system. The treated groundwater from the M1 air stripper treatment system discharges at the A14 Outfall, which is the origin of the M Area outfall tributary. Approximately $250 \mathrm{~m}$ from the A14 outfall, water from other A/M Area outfalls enters the M Area outfall tributary. The length of the M Area outfall tributary is approximately $1435 \mathrm{~m}(1.4 \mathrm{~km})$ measured from the A14 outfall to the confluence with the main channel of Tims Branch. Two notable locations along the M Area outfall tributary are an erosion pond and a footbridge located at the former A11 outfall. In addition to the M Area outfall tributary, a number of key Tims Branch features are depicted in Figure 6, including (from north to south): the wetland treatment system and A01 outfall, Pond 1 (used as a control site in this study), the confluence with the M Area outfall tributary, Beaver Pond 2, Steed Pond, Beaver Pond 3, Beaver Pond 4 and Beaver Pond 5. Tims Branch ends, discharging into Upper Three Runs, in the lower portion of the diagram, approximately $7835 \mathrm{~m}(7.8 \mathrm{~km})$ from the A14 Outfall. A nearby pond, (the D-1 Pond), that served as an additional control site in 2011 is also shown in Figure 6.

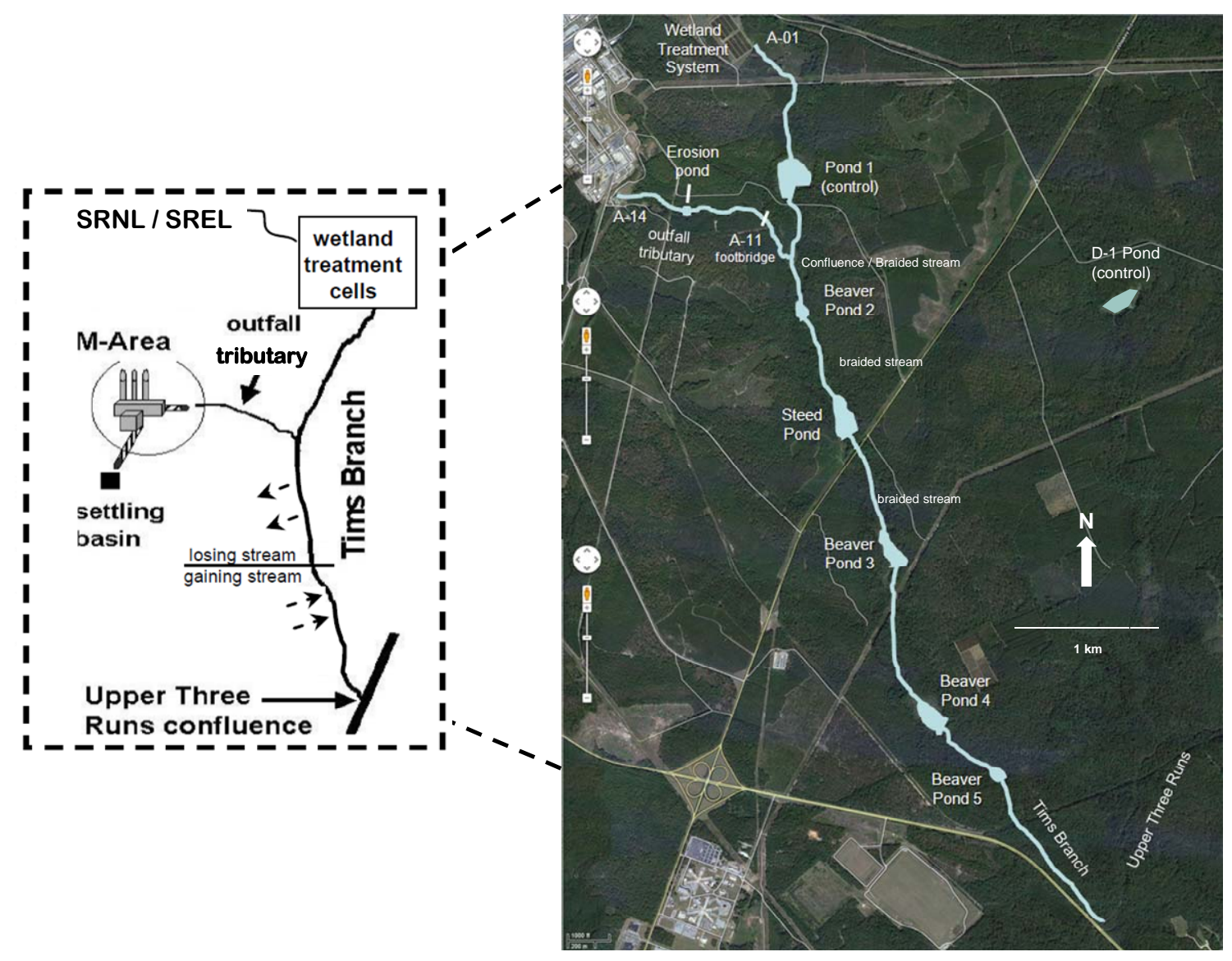

Figure 6. Annotated overhead photograph of the Tims Branch system 
SRNL-STI-2012-00202

Page 15 of 64

Figure 7 provides information about stream morphology and the topographic profile Tims Branch from the A14 outfall to Upper Three Runs. This figure is based on the USGS topographic maps for this area and was adapted from Hayes (1984). The profile has been edited to approximate the changes in elevation due to erosion and includes annotations of sediment deposition sites, including an engineered weir and the associated erosion pond along the M Area Outfall tributary and the several beaver ponds identified above. The most significant feature on the profile is the relatively steep drop along the $M$ Area outfall tributary (leading to a high energy erosional environment with limited and patchy sediment accumulation) transitioning to a lower slope in the main channel (resulting in a depositional setting with areas of braided stream and wetland environments).
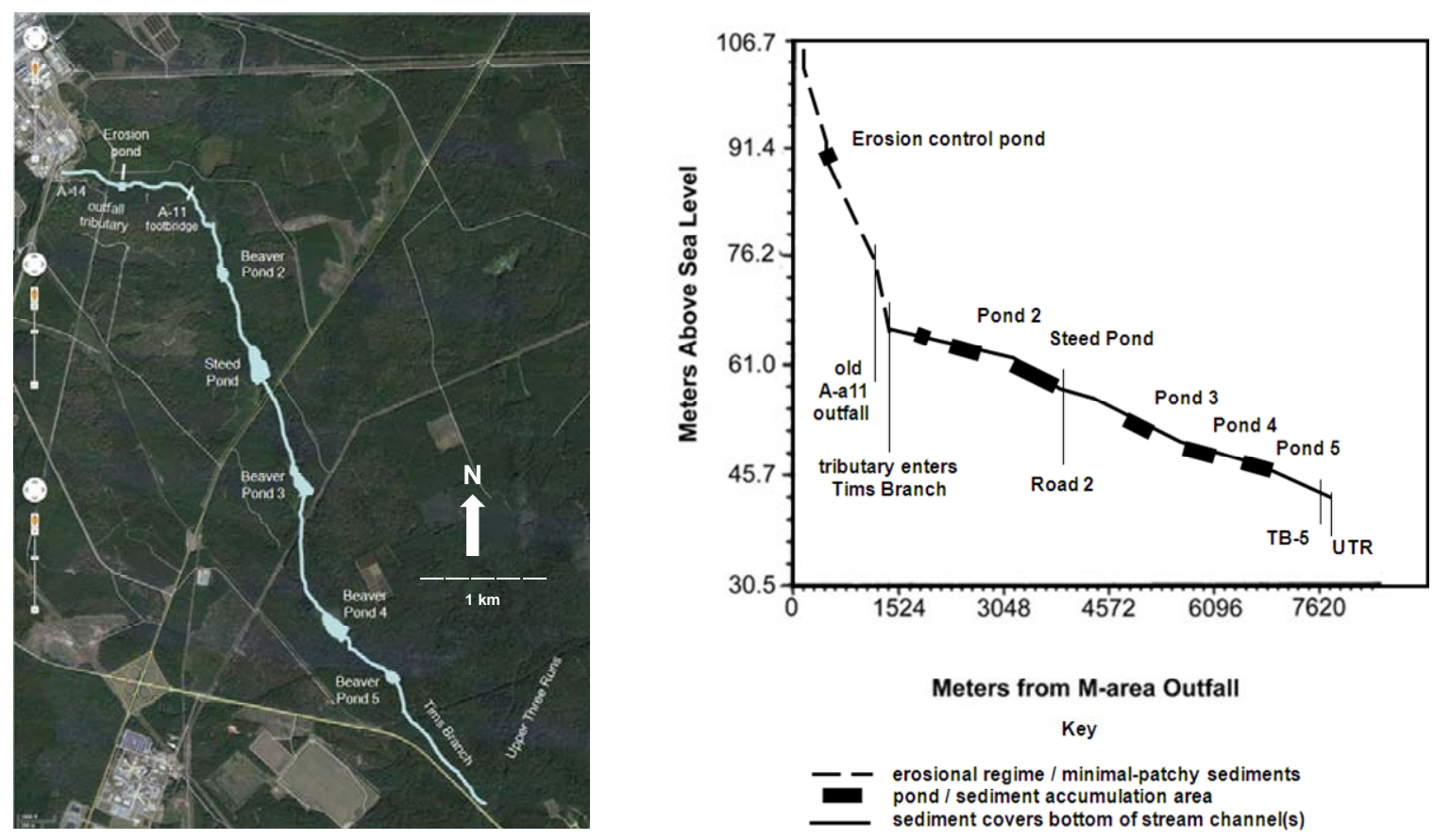

Figure 7. Morphology of M Area outfall tributary and Tims Branch

For the various tasks, water was collected from the air stripper and representative field sampling sites were located throughout the M Area outfall tributary and Tims Branch. The specific sites selected for sampling varied by media (water, sediment, biofilm and biota) and research objective. The approximate locations of key sampling sites (in terms of distance from the A014 outfall) are listed in Table 1 along with brief descriptions and the types of samples collected. 


\begin{tabular}{|c|c|c|}
\hline $\begin{array}{c}\text { TABLE 1. SAMPLING } \\
\text { LOCATIONS }\end{array}$ & $\begin{array}{l}\text { Types of } \\
\text { samples } \\
\text { collected }\end{array}$ & $\begin{array}{c}\text { Approximate } \\
\text { Distance from } \\
\text { the A014 Outfall } \\
(\mathrm{m})\end{array}$ \\
\hline Outlet of M1 Air Stripper System & Water & $\begin{array}{l}\mathrm{N} / \mathrm{A}-\text { process } \\
\text { monitoring }\end{array}$ \\
\hline $\begin{array}{l}\text { D1 Beaver Pond - } \\
\text { Uncontaminated control pond } \\
\text { located on a nearby stream similar } \\
\text { to Tims Branch that feeds into } \\
\text { Upper Three Runs }\end{array}$ & Fish (ORNL) & NA - control \\
\hline $\begin{array}{l}\text { Pond } 1 \text {, control location, a former } \\
\text { farm pond that is on the main } \\
\text { northern tributary of Tims Branch } \\
\text { that receives the discharge from } \\
\text { the A01 wetland treatment system }\end{array}$ & $\begin{array}{l}\text { Sediment, Water, } \\
\text { Fish (SREL and } \\
\text { ORNL), } \\
\text { Invertebrates }\end{array}$ & NA - control \\
\hline $\begin{array}{l}\text { Side stream, control location, } \\
\text { originating from other } \mathrm{A} / \mathrm{M} \text { Area } \\
\text { outfalls that flows into the } \mathrm{M} \text { area } \\
\text { outfall tributary } 230 \mathrm{~m} \text { from the } \\
\text { A14 outfall }\end{array}$ & $\begin{array}{l}\text { Sediment, } \\
\text { Biofilm, Water }\end{array}$ & NA - control \\
\hline $\begin{array}{l}\text { A14 Outfall (origin of M Area } \\
\text { outfall tributary) }\end{array}$ & Water, Biofilm & 1.5 \\
\hline $\begin{array}{l}\text { M Area outfall tributary } \\
\text { immediately downstream of A14 } \\
\text { Outfall }\end{array}$ & $\begin{array}{l}\text { Sediment, } \\
\text { Biofilm }\end{array}$ & 6 \\
\hline M Area outfall tributary & Sediment, & 120 \\
\hline $\begin{array}{l}\text { M Area outfall tributary just } \\
\text { before confluence with stream } \\
\text { originating from the other A/M } \\
\text { Area outfall(s) }\end{array}$ & $\begin{array}{l}\text { Sediment, } \\
\text { Biofilm, Water }\end{array}$ & 230 \\
\hline $\begin{array}{l}\text { Downstream about } 25 \text { feet from } \\
\text { the confluence of the streams } \\
\text { originating from the new A } 11 \\
\text { Outfall and the A } 14 \text { Outfall }\end{array}$ & Water & 245 \\
\hline Erosion Pond (weir site) & $\begin{array}{l}\text { Sediment cores } \\
\text { (SRNL) and bulk } \\
\text { sediment for } \\
\text { methylation } \\
\text { study (ORNL) }\end{array}$ & 580 \\
\hline
\end{tabular}




\begin{tabular}{|c|c|c|}
\hline $\begin{array}{c}\text { TABLE 1. SAMPLING } \\
\text { LOCATIONS }\end{array}$ & $\begin{array}{l}\text { Types of } \\
\text { samples } \\
\text { collected }\end{array}$ & $\begin{array}{c}\text { Approximate } \\
\text { Distance from } \\
\text { the A014 Outfal } \\
(\mathrm{m})\end{array}$ \\
\hline $\begin{array}{l}\text { Between erosion pond and former } \\
\text { A11 Outfall }\end{array}$ & $\begin{array}{l}\text { Sediment, } \\
\text { Fish (ORNL), } \\
\text { Invertebrates }\end{array}$ & 1100 \\
\hline Former A11 Outfall, footbridge & $\begin{array}{l}\text { Sediment, } \\
\text { Biofilm, Water, } \\
\text { Fish (ORNL), } \\
\text { Invertebrates }\end{array}$ & 1130 \\
\hline $\begin{array}{l}\text { Braided stream, confluence of } M \\
\text { Area outfall tributary with Tims } \\
\text { Branch }\end{array}$ & $\begin{array}{l}\text { Sediment, Fish } \\
\text { (ORNL), } \\
\text { Invertebrates, } \\
\text { Water }\end{array}$ & 1435 \\
\hline $\begin{array}{l}\text { Beaver Pond 2, between Former } \\
\text { A011 Outfall and Steed Pond }\end{array}$ & $\begin{array}{l}\text { Sediment, Fish } \\
\text { (SREL and } \\
\text { ORNL), } \\
\text { Invertebrates }\end{array}$ & 2040 \\
\hline $\begin{array}{l}\text { Former United States Geological } \\
\text { Survey (U.S.G.S.) sampling } \\
\text { station, just downstream of Steed } \\
\text { Pond }\end{array}$ & $\begin{array}{l}\text { Sediment, } \\
\text { Biofilm }\end{array}$ & 3200 \\
\hline $\begin{array}{l}\text { Beaver Pond 3, downstream of the } \\
\text { former U.S.G.S. sampling station }\end{array}$ & $\begin{array}{l}\text { Sediment, Fish } \\
\text { (SREL) }\end{array}$ & 4270 \\
\hline $\begin{array}{l}\text { Downstream of Beaver Pond } 3 \text {, in } \\
\text { a braided stream }\end{array}$ & Sediment & 4785 \\
\hline Beaver Pond 4 & $\begin{array}{l}\text { Sediment, Fish } \\
\text { (SREL) }\end{array}$ & 5730 \\
\hline Beaver Pond 5 , in pond & $\begin{array}{l}\text { Sediment, Fish } \\
\text { (SREL) }\end{array}$ & 6400 \\
\hline $\begin{array}{l}\text { Beaver Pond } 5 \text {, channel } \\
\text { downstream of beaver dam }\end{array}$ & Sediment & 6550 \\
\hline $\begin{array}{l}\text { Tims Branch, just before } \\
\text { confluence of Tims Branch with } \\
\text { Upper Three Runs }\end{array}$ & Sediment & 7835 \\
\hline
\end{tabular}




\section{Analytical Methods and Quality Assurance}

Table 2 lists the methods used to analyze the various samples/media and the linkages to the three project tasks. For all analyses certified standards were used for instrument calibration and instrument checking. Duplicates/blanks were run with each batch of samples. For solid matrices such as sediment, biofilm and biota, certified reference standards were run regularly to assure quality. For example, for mercury analysis of 2010 whole body fish samples (analyzed using the Milestone DMA-80 direct mercury analyzer), two certified standards, a duplicate and two blanks were run with each set of 10 samples (see Appendix B). For mercury analysis of 2011 fish tissue samples (analyzed using the Ohio Lumex atomic absorption spectrometer), two digestion blanks, three certified standards, one matrix spike, and three duplicates were run with each set of 20 samples. For total tin analysis in sediment and biofilm (analyzed using x-ray fluorescence using a Niton XL3t-GOLDD+ analyzer ), a certified reference sample was run each day along with low medium and high spiked samples (see Appendix B). Similar protocols were used for all various analyses that support this research.

The low solubility, recalcitrance and stability of solid tin (IV) oxides is a contributor to its low toxicity and potential for minimal ecological impacts. However, development of analytical methods to analyze total tin in biota have proven challenging as a result of these same characteristics. Total tin concentrations in tested tissue samples are generally below the detection limit of x-ray fluorescence. Microwave extraction using nitric acid, nitric acid with trace hydrofluoric acid, and mixed acid (nitric, hydrofluoric and hydrochloric acids) did not provide robust and reproducible extraction of tin oxide standards and spiked tissue samples. The team is actively developing alternative sample preparation and analysis methods. After the methods are developed, the team will complete the Tims Branch screening study. 
SRNL-STI-2012-00202

Page 19 of 64

Table 2. Summary of Analytical Methods

\begin{tabular}{|c|c|c|c|}
\hline Media & Method & Task(s) & Notes \\
\hline Water & $\begin{array}{l}\text { Filter ( } 0.2 \text { um membrane) } \\
\text { and analysis by scanning } \\
\text { electron microscopy (SEM) } \\
\text { and energy dispersive } \\
\text { elemental analysis }\end{array}$ & $\begin{array}{l}\text { Treatment } \\
\text { Process } \\
\text { Characterization }\end{array}$ & $\begin{array}{l}\text { Applied to the } \\
\text { effluent of the } \\
\text { treatment process to } \\
\text { visualize } \\
\text { particulates }\end{array}$ \\
\hline $\begin{array}{l}\text { Sediment (total } \\
\text { tin) }\end{array}$ & $\begin{array}{l}\text { Collect sediment in a core } \\
\text { tube (or grab sample at some } \\
\text { locations). For cores, } \\
\text { extrude core and separate } \\
\text { into depth intervals. Dry for } \\
12 \text { hours at } 60 \mathrm{C} \text { and } \\
\text { disaggregate using a mortar } \\
\text { and pestle. Place a } \\
\text { subsample in an xrf sample } \\
\text { cup with a Proline }{ }^{\circledR} \text { support } \\
\text { membrane and analyze using } \\
\text { x-ray fluorescence. }\end{array}$ & $\begin{array}{l}\text { Geochemical } \\
\text { Monitoring }\end{array}$ & $\begin{array}{l}\text { Applied to all } \\
\text { sediment samples } \\
\text { (see Appendix B) }\end{array}$ \\
\hline $\begin{array}{l}\text { Biofilm (total } \\
\text { tin) }\end{array}$ & $\begin{array}{l}\text { Collect biofilm covered } \\
\text { fibrous root masses (or } \\
\text { biofilm from collection } \\
\text { plates). Dry samples root } \\
\text { mass samples at } 60 \mathrm{C} \text { for } 12 \\
\text { hours and separate biofilm } \\
\text { powder from root mass by } \\
\text { agitation (or scrape biofilm } \\
\text { from plate and freeze dry). } \\
\text { Disaggregate in a morter and } \\
\text { pestle or grind sample. } \\
\text { Place a subsample in an xrf } \\
\text { sample cup with a Proline }{ }^{\circledR} \\
\text { support membrane and } \\
\text { analyze using X-ray } \\
\text { fluorescence (Niton XL3t- } \\
\text { GOLDD+ analyzer). }\end{array}$ & $\begin{array}{l}\text { Geochemical } \\
\text { Monitoring }\end{array}$ & $\begin{array}{l}\text { Applied to all } \\
\text { biofilm samples (see } \\
\text { Appendix B) }\end{array}$ \\
\hline Water (total tin) & $\begin{array}{l}\text { Collect samples using a } \\
\text { long-handle Teflon }{ }^{\circledR} \text { cup into } \\
\text { precleaned sample containers } \\
\text { (certified for metals } \\
\text { analysis). Acidify using } \\
\text { trace metal grade nitric acid. } \\
\text { Analyze for tin using } \\
\text { inductively coupled plasma- } \\
\text { mass spectrometry (ICP- } \\
\text { MS). }\end{array}$ & $\begin{array}{l}\text { Geochemical } \\
\text { Monitoring }\end{array}$ & $\begin{array}{l}\text { Applied to water } \\
\text { from the M Area } \\
\text { outfall tributary and } \\
\text { Tims Branch }\end{array}$ \\
\hline
\end{tabular}


SRNL-STI-2012-00202

Page 20 of 64

Table 2. Summary of Analytical Methods

\begin{tabular}{|c|c|c|c|}
\hline Media & Method & Task(s) & Notes \\
\hline $\begin{array}{l}\text { Water } \\
\text { ("dissolved" } \\
\text { tin) }\end{array}$ & $\begin{array}{l}\text { Collect samples using a } \\
\text { long-handle Teflon }{ }^{\circledR} \text { cup into } \\
\text { precleaned sample containers } \\
\text { (certified for metals } \\
\text { analysis). Filter ( } 0.2 \text { um } \\
\text { membrane) and acidify using } \\
\text { trace metal grade nitric acid } \\
\text { and analyze for tin using } \\
\text { ICP-MS). }\end{array}$ & $\begin{array}{l}\text { Geochemical } \\
\text { Monitoring }\end{array}$ & $\begin{array}{l}\text { Applied to water } \\
\text { from the M Area } \\
\text { outfall tributary and } \\
\text { Tims Branch }\end{array}$ \\
\hline $\begin{array}{l}\mathrm{pH}, \text { anions, } \\
\text { organic carbon }\end{array}$ & $\begin{array}{l}\text { Measured using standard } \\
\text { laboratory methods such as } \\
\text { pH meter, ion } \\
\text { chromatography and organic } \\
\text { carbon analyzer }\end{array}$ & $\begin{array}{l}\text { Geochemical } \\
\text { Monitoring }\end{array}$ & $\begin{array}{l}\text { Applied to water } \\
\text { from the M Area } \\
\text { outfall tributary and } \\
\text { Tims Branch }\end{array}$ \\
\hline $\begin{array}{l}\text { Mercury in } \\
\text { biota (total) }\end{array}$ & $\begin{array}{l}\text { Measured using Milestone } \\
\text { Direct Mercury Analyzer } \\
\text { (DMA 80) -- thermal } \\
\text { decomposition, trapping and } \\
\text { atomic absorption }\end{array}$ & $\begin{array}{l}\text { Biological } \\
\text { Monitoring }\end{array}$ & $\begin{array}{l}\text { Applied to } 2010 \\
\text { whole body fish } \\
\text { samples (SREL) }\end{array}$ \\
\hline $\begin{array}{l}\text { Mercury in } \\
\text { biota (total) }\end{array}$ & $\begin{array}{l}\text { Measured using extraction } \\
\text { followed by Ohio Lumex } \\
\text { atomic absorption } \\
\text { spectrometer }\end{array}$ & $\begin{array}{l}\text { Biological } \\
\text { Monitoring }\end{array}$ & $\begin{array}{l}\text { Applied to } 2010 \\
\text { biota samples } \\
(\text { ORNL) }\end{array}$ \\
\hline $\begin{array}{l}\text { Mercury in } \\
\text { biota (total) }\end{array}$ & $\begin{array}{l}\text { Measured using microwave } \\
\text { extraction followed ICP-MS }\end{array}$ & $\begin{array}{l}\text { Biological } \\
\text { Monitoring }\end{array}$ & $\begin{array}{l}\text { Applied to } 2006 \\
\text { biota samples } \\
\text { (SREL) }\end{array}$ \\
\hline
\end{tabular}




\section{Results}

\section{Treatment Process Characterization}

A principal goal of this effort is to confirm the nature and quantity of tin released from the mercury treatment process based on thermodynamic models, SEM data and analysis of tin in water samples.

Thermodynamic-equilibrium geochemical modeling (The Geochemist's Workbench ${ }^{\circledR}$; Bethke, 2009) provides the initial basis to predict the geochemical phases of tin in treated water exiting the M1 air stripper. Figure 8 is an example of modeling results showing a pe-pH diagram with stability fields for the dominant tin species at a total tin concentration of approximately $12 \mu \mathrm{g} / \mathrm{L}\left(10^{-7} \mathrm{M}\right)$. The bulk water chemistry (anions and cations) listed as input data are typical for the treated groundwater in this area (Strom and Kaback, 1992). The diagram indicates that tin is predicted to precipitate as a solid in this dilute system at $\mathrm{pH}$ values from 0 to 10 and pe values from -5 to +5 and above. All of the species in the diagram are solid precipitates (designated by the tan background). At equilibrium, dissolved tin and aqueous complexes are minor constituents compared to the various solid species shown. Moreover, for the specific pe and $\mathrm{pH}$ conditions of the outfall, solid tin(IV) oxide precipitate is the strongly predominant tin moiety.

To explicitly confirm the formation of tin solids, we collected samples of water exiting the air stripper and concentrated particulates on a $0.2 \mu \mathrm{m}$ membrane filter for SEM analysis. Figures 9 and 10 document the SEM results. In Figure 9, panels A and B were imaged using a Quadrant Back Scattering Detector (QBSD) and panel C using the a Secondary Electrons Detector (SE1). The QBSD signal is a function of the atomic number whereas the SE1 signal is insensitive to atomic number. The practical result of these characteristics is that particles that are predominantly composed of heavier elements, such as tin, would be relatively brighter on the QBSD image (versus silica or aluminum) and would be similar in appearance on the SE1. Panel A is a wide-field QBSD image of the small particles in the treated water showing the presence of two distinct types of particles (based on brightness). Panel B and C show a bright flocculated cluster at higher magnification on the QBSD and SE1, respectively. The elemental composition of this same flocculated cluster, along with nearby particulates was measured using energy-dispersive x-ray spectroscopy (EDX) and is shown in Figure 10. The bright cluster (SPOT-2) is predominantly tin and oxygen (tin oxide(s)) while the nearby particles (SPOT-1) are predominantly aluminum, silicon and oxygen (“aluminosilicates”). 


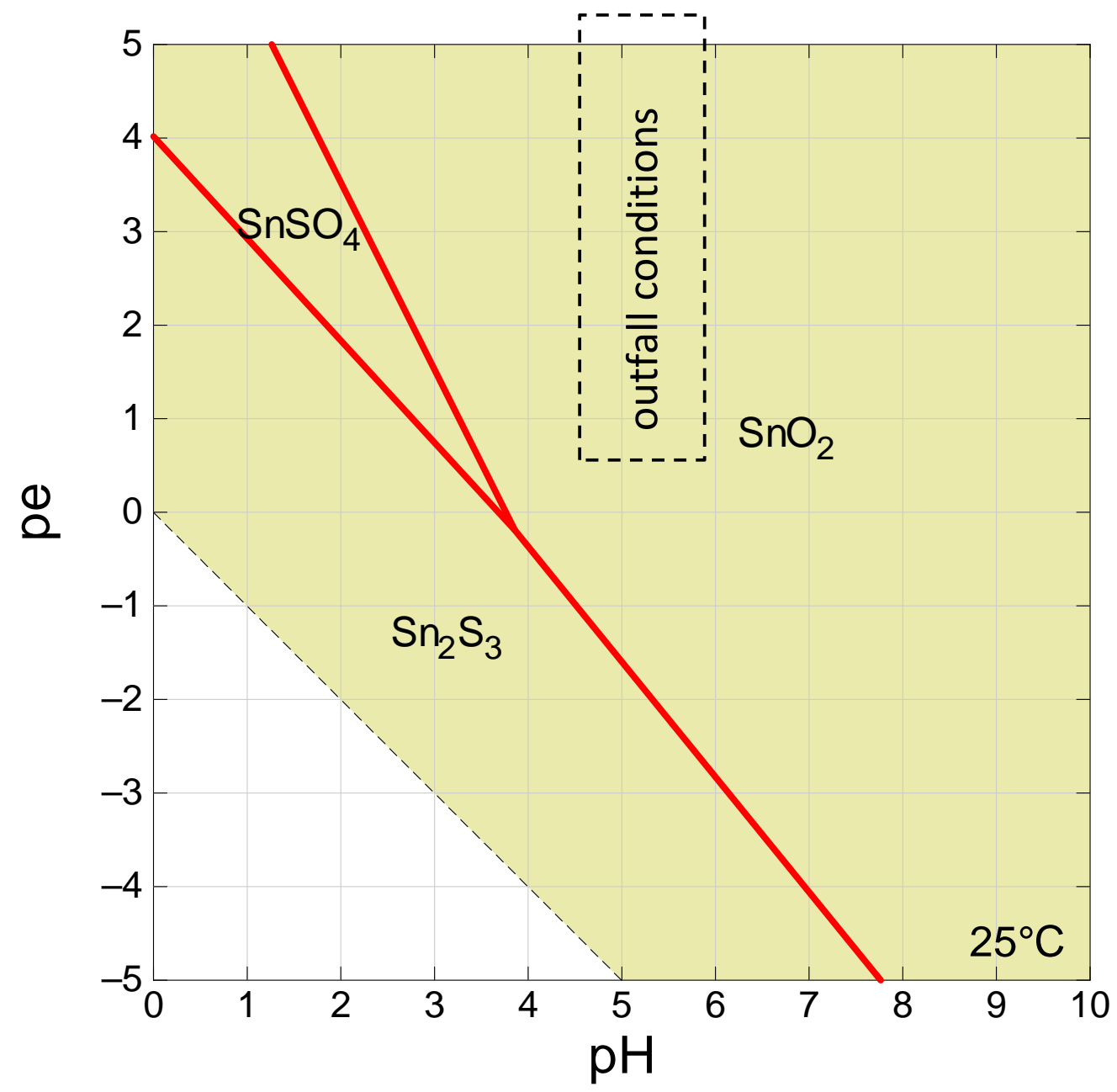

Figure 8. Geochemical speciation of tin for outfall conditions

(Input data: tin $\cong 1 \times 10^{-7} \mathrm{M}(12 \mu \mathrm{g} / \mathrm{L})$, sodium $\cong 3.0 \times 10^{-5} \mathrm{M}$, calcium $\cong 1.7 \times 10^{-5} \mathrm{M}$, magnesium $\cong 1.8 \times 10^{-5} \mathrm{M}$, potassium $\cong 5.0 \times 10^{-6} \mathrm{M}$, chloride $\cong 1.1 \times 10^{-4} \mathrm{M}$, sulfate $\cong 1.5 \times 10^{-6} \mathrm{M}$, fluoride $\cong 2.1 \times 10^{-6} \mathrm{M}$, carbon dioxide $\cong 1 \times 10^{-3}$ fugacity) 

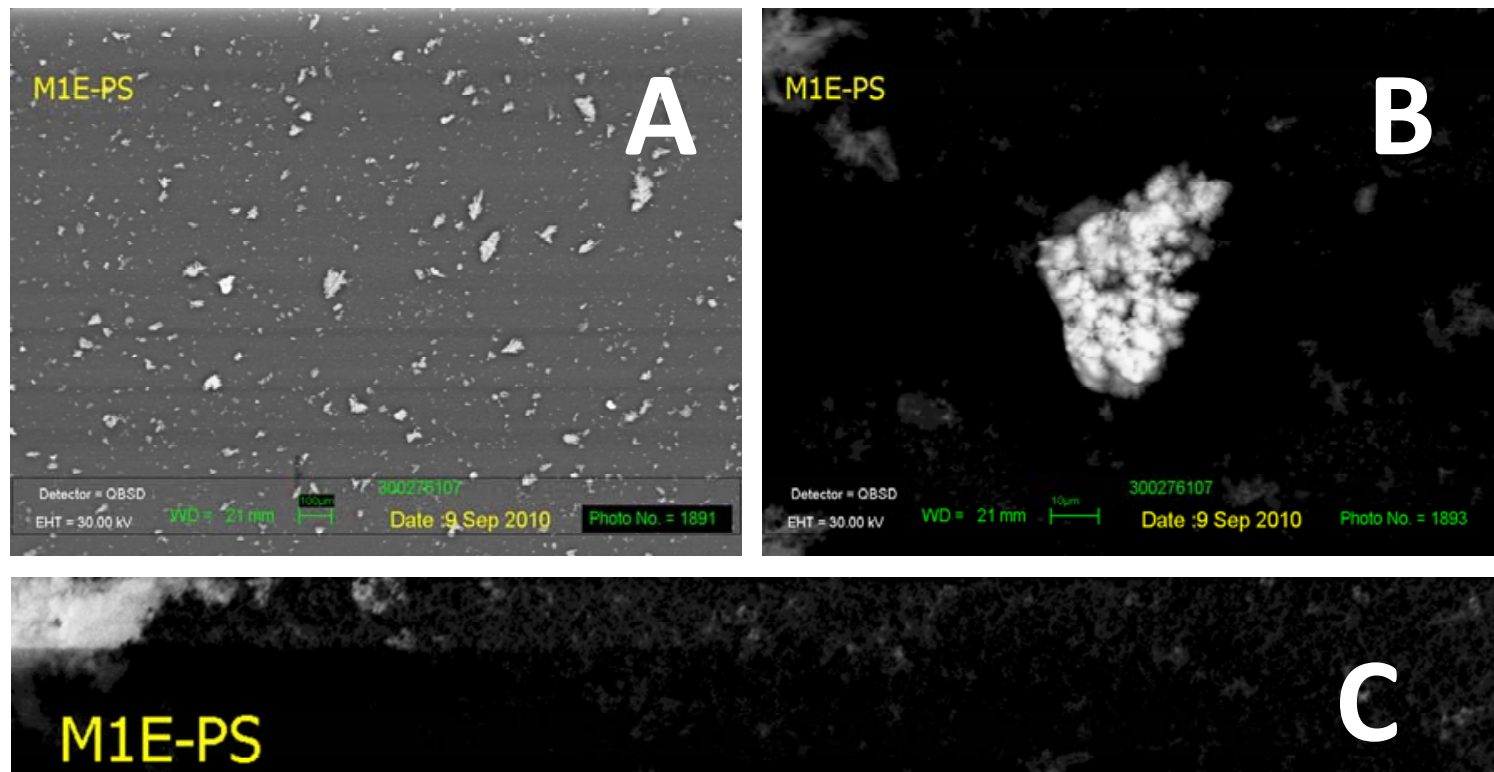

Detector $=$ SE 1

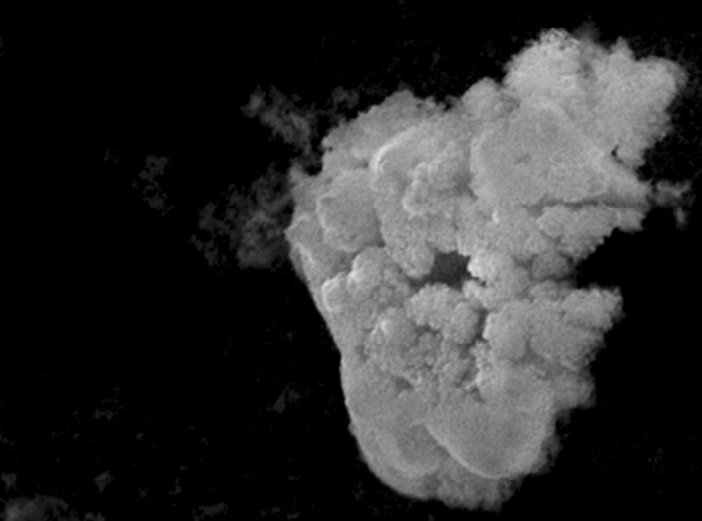

ref

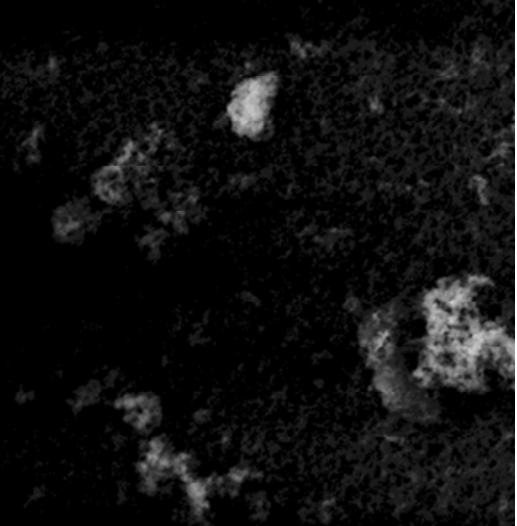

Figure 9. SEM images of particulates in water exiting the M1 Air Stripper

A) wide-field micrograph, B) flocculated tin oxide particle (QBSD),

C) flocculated tin oxide particle (SE1) 

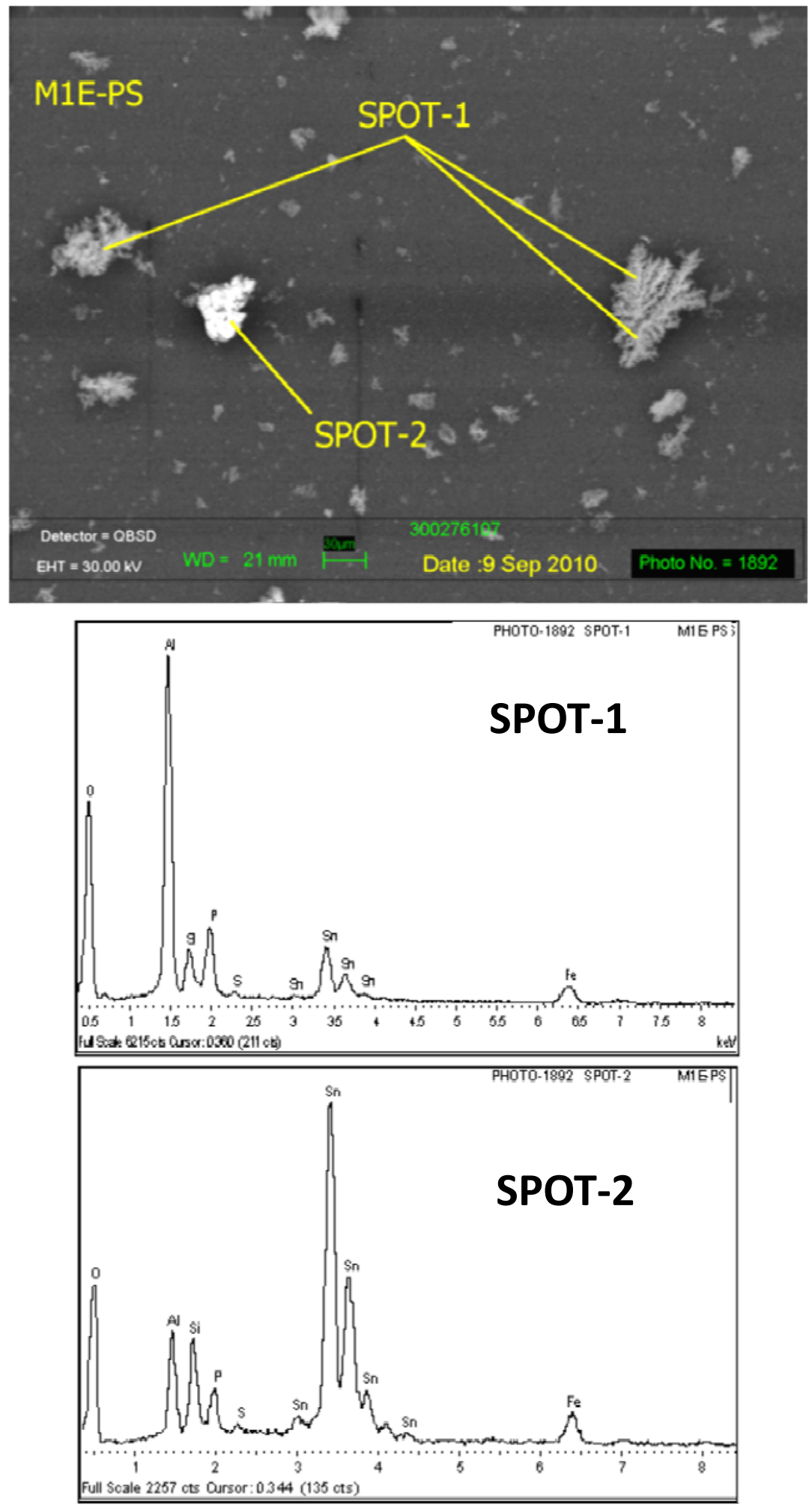

Figure 10. Elemental fingerprints for SPOT-1 (aluminosilicate) and SPOT-2 (oxidized tin solid) 


\section{Geochemical Monitoring}

The primary compartments and phases measured to support geochemical monitoring were water, sediment and biofilm. The results for these compartments/phases are discussed below.

The water collections occurred in the August 2010; at this time the full scale tin(II) based treatment had operated at the M1 air stripper for approximately 2.75 years and the water in the Tims Branch would represent a "steady-state" condition. Seven locations and a field blank were included in the screening survey and were analyzed by ICP-MS. The sample locations were: groundwater entering the M1 stripper system, treated water exiting the M1 treatment system, 3 locations in the M Area outfall tributary, 1 location in the braided stream below the confluence with Tims Branch, and one location in the Pond 1 control site. At each location, an unfiltered "total" sample and a filtered "dissolved and colloidal" sample were collected-processed and analyzed. All of the data are organized and presented in Figure 11. Total tin concentrations ranged from $<0.5 \mu \mathrm{g} / \mathrm{L}$ to $103 \mu \mathrm{g} / \mathrm{L}$. The concentrations of tin in the field blank, air stripper inlet, and control site were all below the detection limit. Based on data presented in Looney et al. (2010) the high concentration and high particulate fraction measured at the outlet of the M1 air stripper exceed the steady state values and are artifacts of difficult-to-purge particulate tin that has accumulated in the fittings and tubing of the sampling "side-stream". The sample collected at the A014 outfall, where the water enters Tims Branch has a total tin concentration, $21.2 \mu \mathrm{g} / \mathrm{L}$, closely matching the expected steady state value. This sample is most representative of the long term water quality of the discharge to Tims Branch. The combination of the loss of tin (e.g., to sediments and biofilm) and dilution by additional flow from other outfalls results in lower levels of aqueous tin in the downstream sampling locations in the M Area outfall tributary (the erosion pond and the former A11 Outfall). The total tin concentrations at these locations, and in the braided area downstream of the confluence, are approximately 2 to $3 \mu \mathrm{g} / \mathrm{L}$. For the representative outfall samples, $42 \%$ to $63 \%$ of the total tin is captured by a $0.2 \mu \mathrm{m}$ membrane filter. The remaining tin is either dissolved or colloidal. Various investigators (e.g., Ristić et al., 2002) document the tendency of tin oxides to form small particles (e.g., in the range of 0.005 to $0.1 \mu \mathrm{m}$ diameter). The data indicate that over $40 \%$ of the tin in water treated released Tims Branch is particulate. Further study is needed to refine the nature of the tin in the filtered samples. 


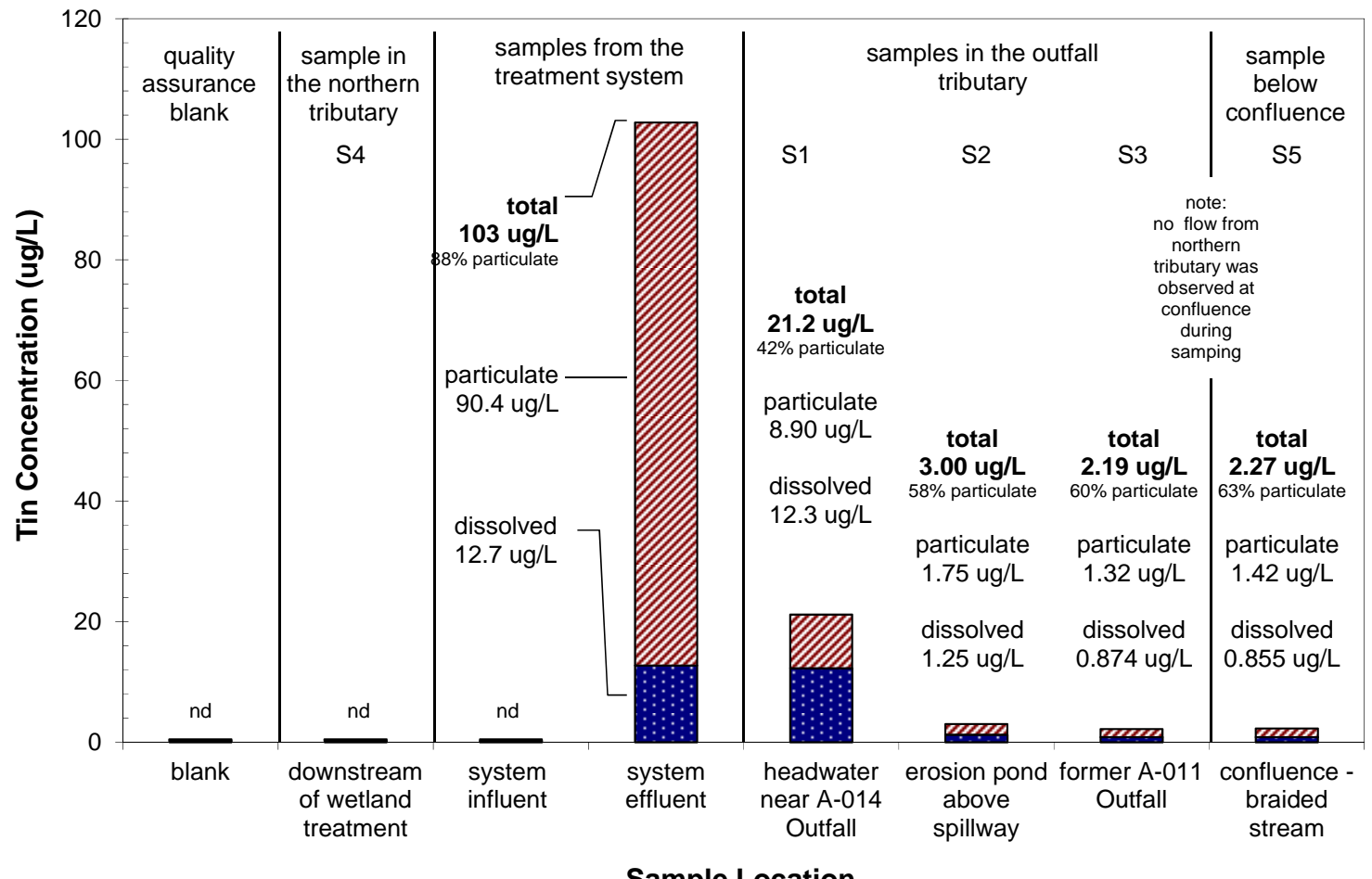

Figure 11. Water concentrations for tin in M Area outfall tributary and Tims Branch

Stream and pond sediments are an ecosystem compartment that provides an early indication of the distance over which inorganic tin impacts are detectable in Tims Branch. To support such a goal, we collected sediment cores from the outfall tributary, various downstream ponds and stream reaches, and a control site. The collections occurred in the summer of 2011; thus, the data reflect approximately 3.5 years of operation of the full scale tin(II) based mercury treatment at the M1 air stripper. Over 200 sediment samples were analyzed in duplicate using xrf. These samples comprised multiple depths from 48 locations, including: 33 in the outfall tributary (spatial segment 1), 7 between confluence and Steed Pond (spatial segment 2), 7 between Steed Pond and UTR (spatial segment 3), and a control site. Tin concentrations in the sediment samples ranged from the detection limit $(<12 \mu \mathrm{g} / \mathrm{g})$ up to $381 \mu \mathrm{g} / \mathrm{g}$. All of the data are reported in Betancourt and Looney (2011).

Figure 12 organizes and summarizes the sediment data. The highest concentrations of tin in surficial sediment (top $2.5 \mathrm{~cm}$ ) were measured in spatial segment 1, the outfall tributary, with a median concentration of approximately $59 \mu \mathrm{g} / \mathrm{g}$. The median tin concentration in surficial sediment in spatial segment 2 (confluence to Steed Pond) was approximately $24 \mu \mathrm{g} / \mathrm{g}$ and the tin concentration in spatial segment 3 (the lower ponds and reaches of Tims Branch) were near the detection limit $(<12 \mu \mathrm{g} / \mathrm{g})$. In general, the highest concentrations were measured closest the discharge location, and concentrations tended to be higher in areas of sediment trapping or accumulation (e.g., erosion pond and beaver pond) and lower in flowing stream reaches, particularly in eroding areas with fast flow (Betancourt and Looney, 2011). The sediment data suggest that detectable levels/impacts of inorganic tin discharged over approximately 3.5 years extend to $3 \mathrm{~km}$ $(3000 \mathrm{~m})$ from the discharge location. 


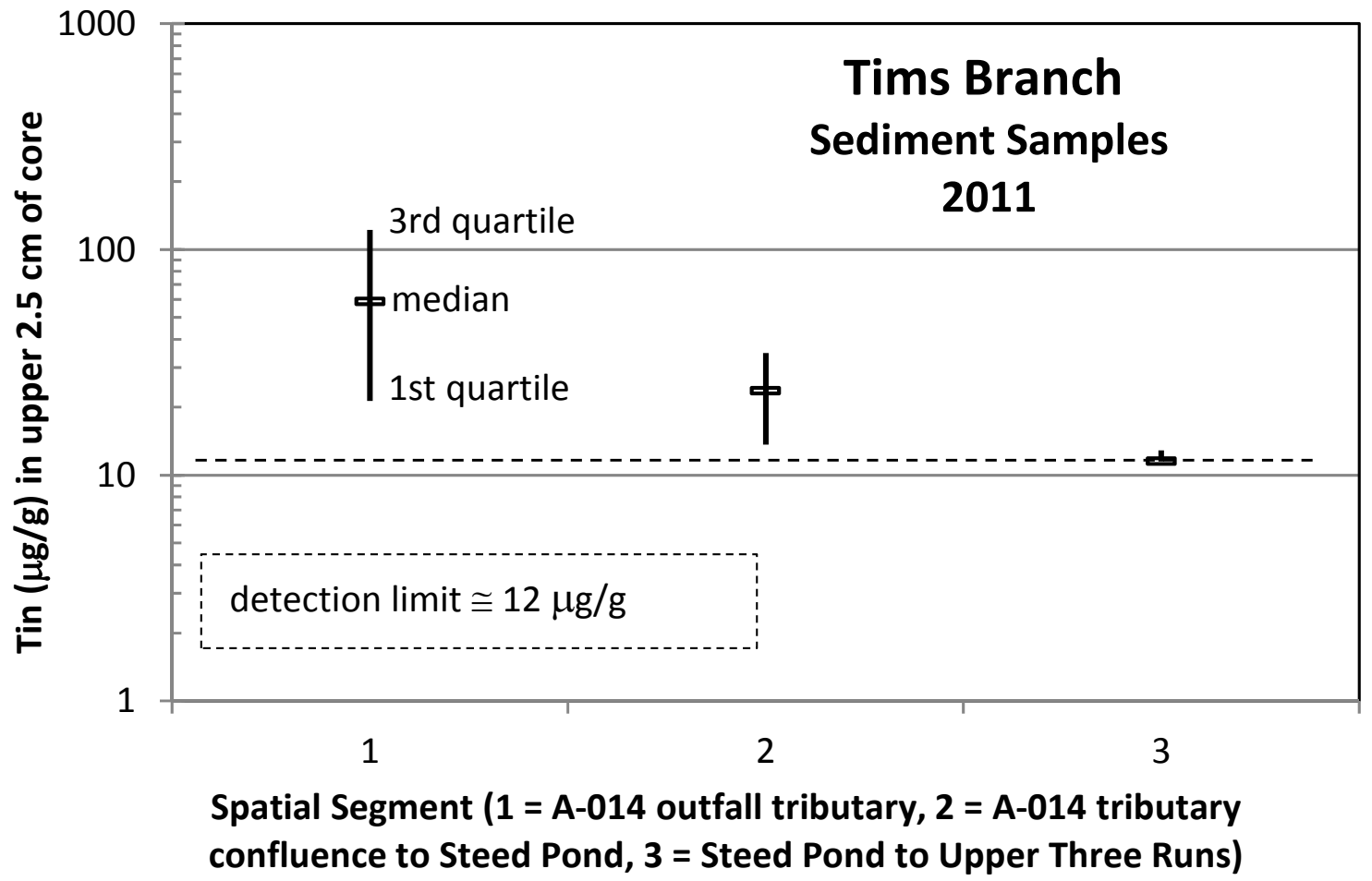

Figure 12. Sediment concentrations for tin in M Area outfall tributary and Tims Branch

A screening study of biofilm was also performed in the summer of 2011 (coincident with collection of the sediment samples). Samples of Tims Branch biofilm were collected to provide additional information on the extent of detectable tin impacts in Tims Branch. At each location where a "biofilm" sample was collected, we removed a section of biofilm-coated substrate and placed the material in a plastic bag for processing (drying / rubbing the sample to separate biofilm "powder" from any substrate) and xrf analysis. The substrate for the biofilm was typically a mass of root fibers or similar fibrous material found in a stream "snag" area. Note that this was a screening study and samples collected in this manner may contain significant quantities of detritus and particulate matter (relative to traditional biofilm samples that are collected on flat plates after a period of colonization/growth). The screening biofilm samples were supplemented by analyzing a traditional (flat plate) biofilm sample collected in Beaver Pond 2 by Paul Edwards, a graduate student at Eastern Illinois University. In total, 8 biofilm samples were analyzed in duplicate using xrf, including: 4 locations in the outfall tributary, 3 locations in Tims Branch, and a control.

The biofilm results are shown in Figure 13. Concentrations in biofilm were reported in Betancourt and Looney (2011) and ranged from the detection limit $(<12 \mu \mathrm{g} / \mathrm{g})$ up to $10,640 \mu \mathrm{g} / \mathrm{g}$. The highest concentrations were measured immediately downstream of the discharge location for treated water from the M1 air stripper. The data suggest that inorganic tin released to Tims Branch is accumulating to relatively high concentrations in near-field biofilm. The concentrations of tin in biofilm exhibit a clear trend (decreasing downstream from the source). The quantitative and qualitative behavior of the trend in tin concentration in biofilm is similar to observed trends for other metals (e.g., zinc, copper, etc.) in biofilms downstream of urban and industrial environments (Fuchs et al., 1997). Due to the high concentrations measured in biofilm, additional research on the uptake mechanisms and speciation of tin in this ecosystem compartment and the potential 
SRNL-STI-2012-00202

Page 28 of 64

impacts (e.g., to sensitive biota) may be warranted. The concentrations of tin in biofilms decrease approximately linearly (as a function of distance); notably, the traditional biofilm sample collected by EIU using a colonized flat plate falls on the trend line from the remaining screening samples, suggesting that the collection methods may generate equivalent data. Based on the results, biofilms appear to be a sensitive indicator of the spatial extent of detectable tin impacts in Tims Branch. Similar to the sediment data, the Biofilm results indicate that detectable impacts of inorganic tin discharged over approximately 3.5 years extend to $3 \mathrm{~km}(3000 \mathrm{~m})$ from the discharge location. The concordance between the sediment data and the biofilm data, and the similarity of the measured "penetration" distance of detectable tin into Tims Branch, suggests that the extensive braided streams and pond environments downstream of the outfall tributary confluence serve as a setting where the tin is deposited and sequestered, currently limiting the magnitude of further downstream transport of significant quantities of tin. David Kling and Larry Bryan have developed an improved biofilm collector and deployed a prototype near A14 to support additional research.

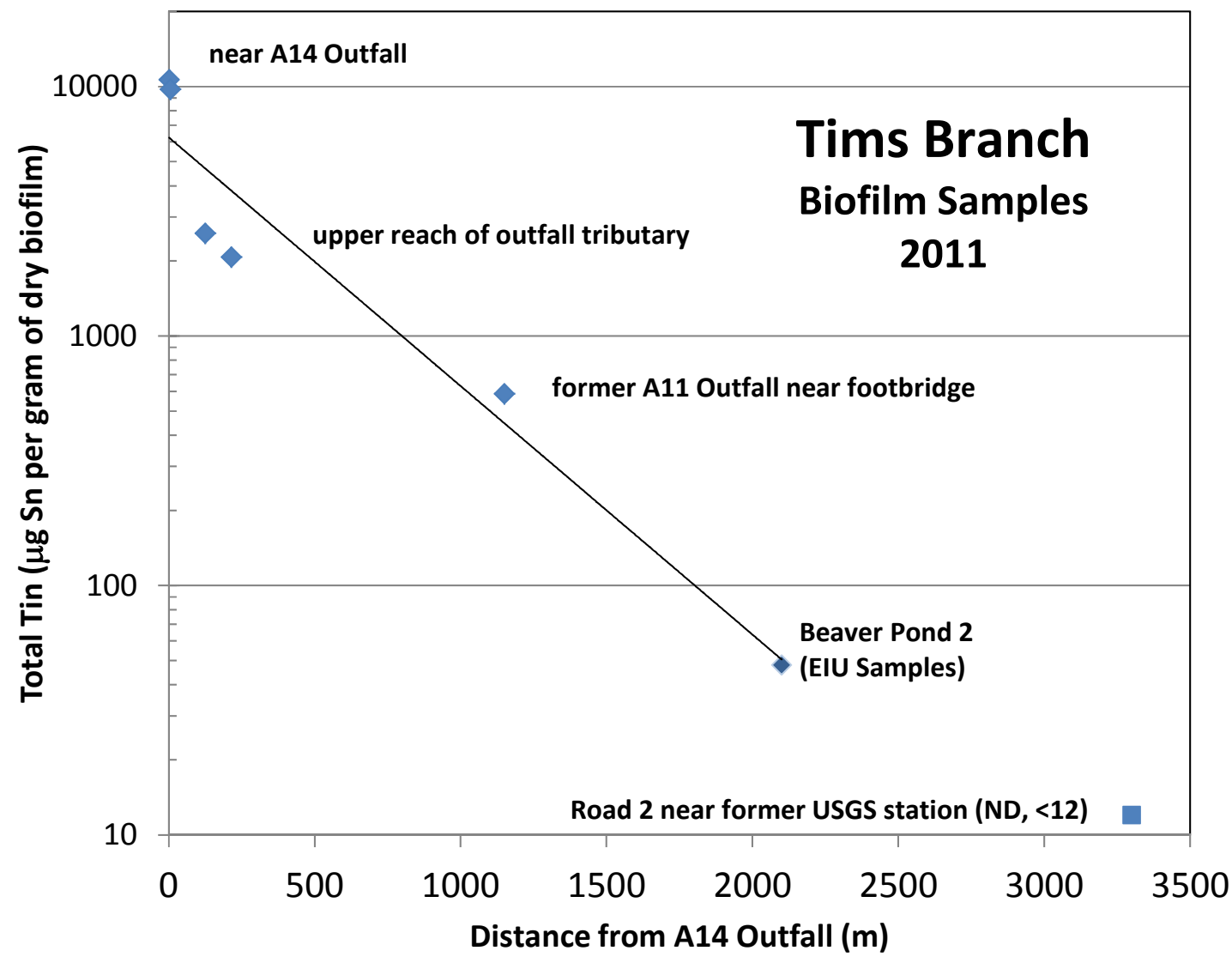

Figure 13. Biofilm concentrations for tin in M Area outfall tributary and Tims Branch 


\section{Biological Monitoring}

The results for all of the fish collected and analyzed for whole body concentrations in 2006 and 2010 are tabulated in Appendix C. Of the fish analyzed, redfin pickerel (Esox americanus americanus) was selected as a target species in this study, as this species is abundant throughout the Tims Branch watershed and is representative of an upper trophic level fish in this system. Figure 14 shows the mercury concentration in all redfin pickerel collected in each pond and for each time period as a function of length (see Appendix C). The data are for Pond 1 (control) and for Beaver Ponds 2, 3, and 4 downstream of the $\mathrm{M}$ Area outfall tributary. The regression analysis in Figure 14 was used to estimate a nominal concentration for a standardized length of $150 \mathrm{~mm}$ - this statistical approach has proven to be useful for sites where the slopes are different for the concentration-length relationship in the different datasets (e.g., year and pond) and is robust when the average size for each dataset is relatively close the selected nominal length (e.g., Sonesten, 2003). The regression method also allows straightforward calculation of confidence intervals for the nominal length. Figure 15 summarizes the average concentration and 95\% confidence interval for each pond and year for a nominal $150 \mathrm{~mm}$ length redfin pickerel.

The data in Figure 15 indicate that mercury concentrations in fish decreased significantly between 2006 and 2010 in all three pond sampling locations downstream of the M Area outfall tributary. In Beaver Pond 2 (a downstream sampling location close to the confluence with the outfall tributary) the average concentration for redfin pickerel decreased approximately $72 \%$, from $3.4 \mu \mathrm{g} / \mathrm{g}$ in 2006 before treatment to $0.96 \mu \mathrm{g} / \mathrm{g}$ in 2010 after treatment. The average 2010 redfin pickerel concentration for all of the downstream sampling locations is below $1 \mu \mathrm{g} / \mathrm{g}$ and observed post-treatment concentrations are similar to the upstream control site which has remained relatively constant in these two datasets, $0.53 \mu \mathrm{g} / \mathrm{g}$ in 2006 and $0.44 \mu \mathrm{g} / \mathrm{g}$ in 2010.

Note that all of the concentrations reported above were generated to support ecological food chain studies and are for whole body (w.b.) samples reported on a dry weight (d.w.) basis. Fish consumption standards are normally reported for fillet and are based on wet weight (w.w.). For example, the EPA AWQC based on a target mercury concentration of $0.3 \mu \mathrm{g} / \mathrm{g}$ in fish fillets on a wet weight basis. Concentrations based on d.w. versus w.w. differ substantially due to the high moisture content in biotic tissue. The moisture content of w.b. redfin pickerel samples in this study clustered around a fraction of 0.78. Therefore, the mercury concentration on a wet weight (w.w.) basis would be estimated by multiplying the d.w. concentration by 0.22 . For example, a w.b. fish measuring $3.4 \mu \mathrm{g} / \mathrm{g}$ d.w, a typical pretreatment concentration in Beaver Pond 2, would be approximately 0.75 $\mu \mathrm{g} / \mathrm{g}$ on a w.w. basis. Post treatment w.b. fish are typically $1 \mu \mathrm{g} / \mathrm{g} \mathrm{d}$.w. or approximately $0.22 \mu \mathrm{g} / \mathrm{g}$ on a w.w. basis. A number of studies indicate that w.b. concentrations and fillet concentrations are strongly correlated (Becker and Bigham, 1995). For example, based on data from analysis of 210 fish representing 13 upper trophic level species, Peterson et al. (2005) developed the following regression: $\log _{10}$ (w.b. w.w.) $=0.9005$ $\log _{10}\left(\right.$ fillet w.w.) $-0.2712\left(r^{2}=0.96\right)$. Using this regression, the w.b. data summarized in Figure 14 and an average moisture content of 0.78 , the estimated fillet concentrations for typical redfin pickerel in Beaver Pond 2 are projected to have decreased from approximately $1.45 \mu \mathrm{g} / \mathrm{g}$ w.w. in 2006 to approximately $0.36 \mu \mathrm{g} / \mathrm{g}$ w.w. in 2010. 


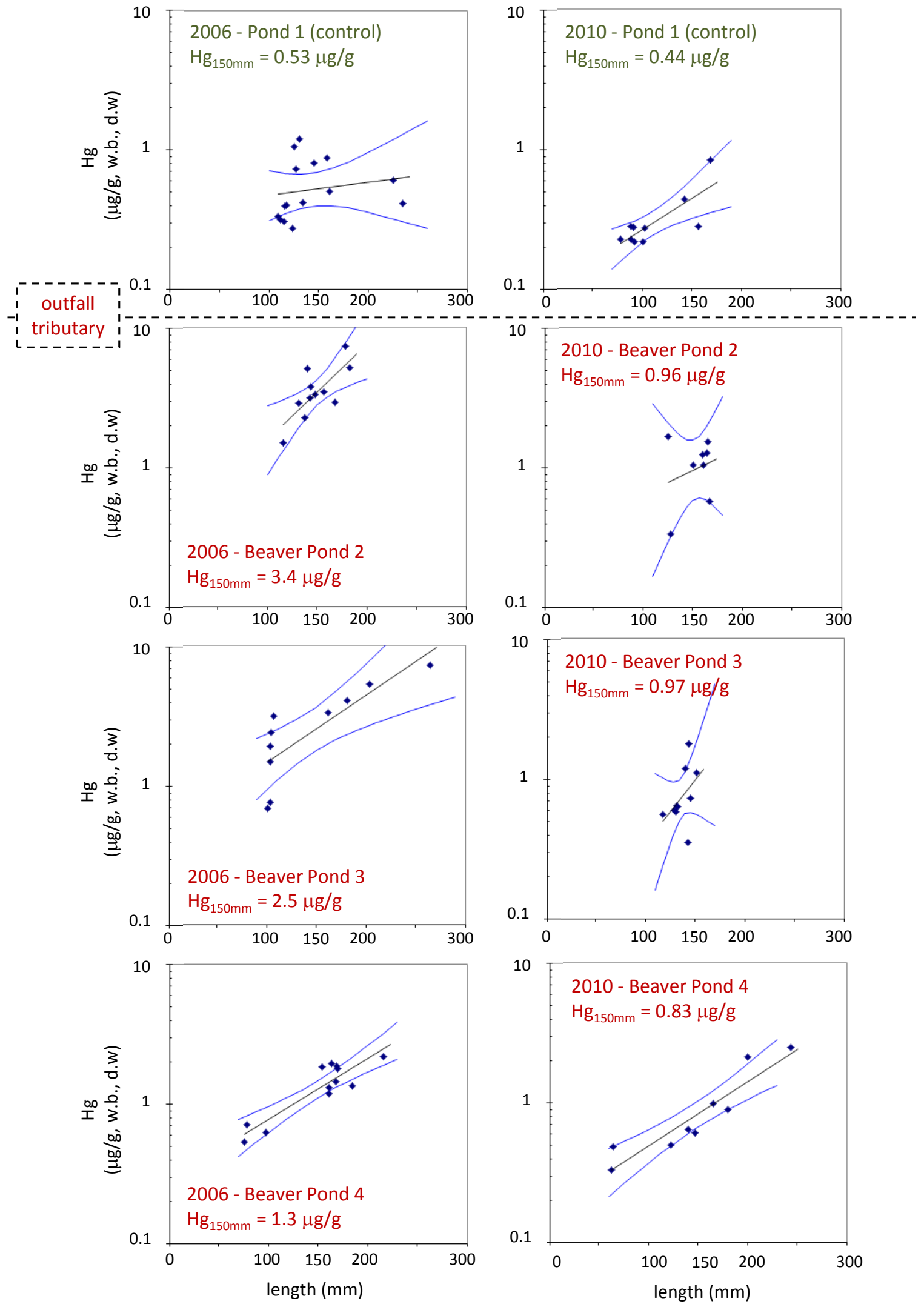

Figure 14. Mercury concentration in redfin pickerel collected from Tims Branch ponds in 2006 (pretreatment) and 2010 (post-treatment) as a function of length

The concentration trend and $95 \%$ confidence interval are shown; the average concentration for a nominal $150 \mathrm{~mm}$ length is noted for each location / time 


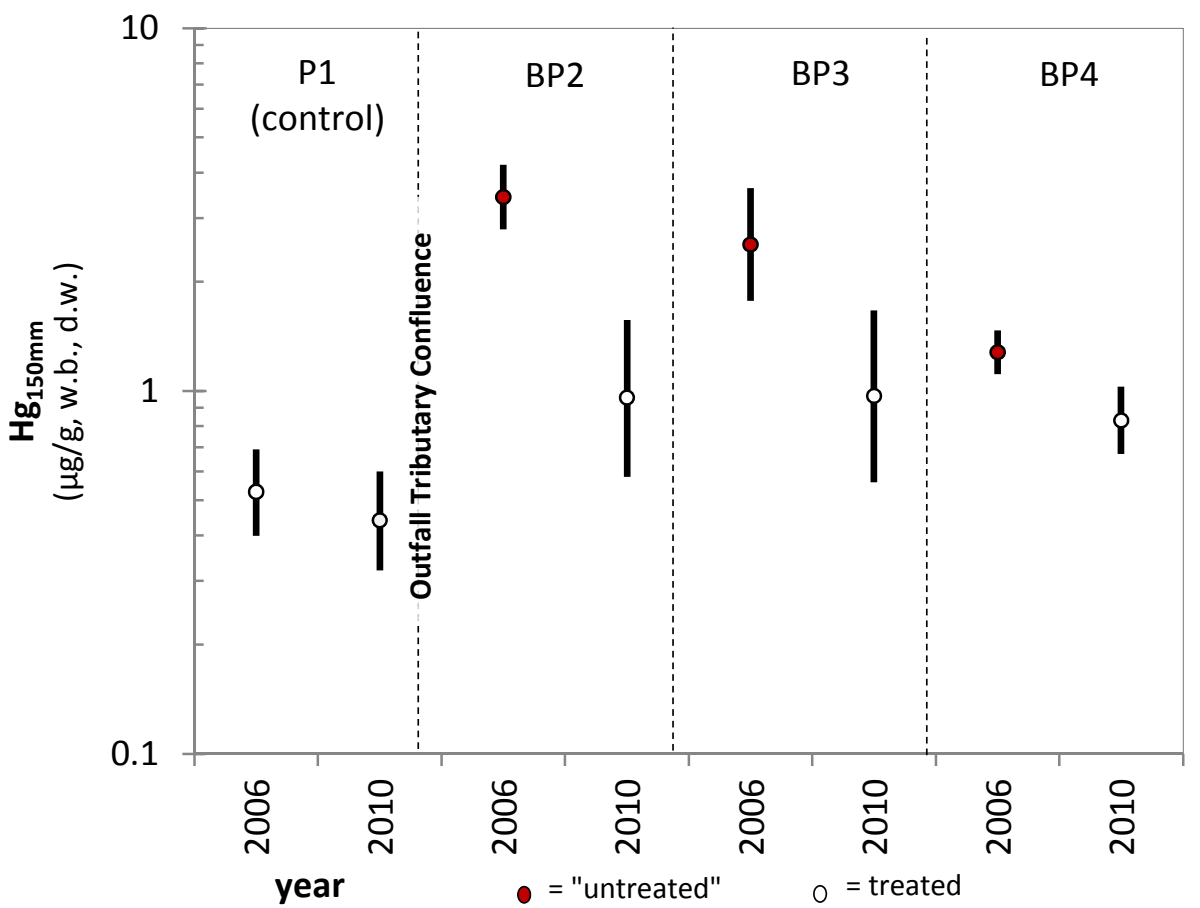

Figure 15. Summary of mercury concentration for nominal 150mm length redfin pickerel collected from Tims Branch ponds in 2006 (pre-treatment) and 2010 (post-treatment)

Data points are the average and the lines show the $95 \%$ confidence interval

It is clear from Figure 15 that mercury concentrations in redfin pickerel decreased significantly from 2006 (prior to tin(II) based mercury treatment) to 2010 (posttreatment), and this decrease was most evident at pond sites closest to the treatment system. In contrast to mercury bioaccumulation which occurs predominantly through food chain exposure, tin uptake most likely occurs through direct exposure (water, sediments), and would be expected to accumulate in the gills and digestive tracts of animals. The assimilation of inorganic tin from the gills and from the gut into other tissues (e.g. muscle) is expected to be very low, but elevated tin exposure to gills and/or digestive tracts may result in adverse effects. Because geochemical analyses have shown elevated tin concentrations in sediments and biofilm in the outfall tributary and upper portions of Tims Branch (Figs. 12 and 13), fish and invertebrates were collected in these portions of the stream in 2011 and were dissected to evaluate whether elevated tin exposure results in enhanced tin accumulation. Animals that feed on sediments or biofilm (invertebrates, herbivorous fish) would be most at risk for tin toxicity.

While tin data for these samples is pending and will be presented in a future report, preliminary results (Figure 16) for $\mathrm{Hg}$ concentrations in composite samples of whole body dusky shiners (Notropis cummingsae), a forage fish found throughout the Tims Branch watershed, had lower $\mathrm{Hg}$ concentrations in the outfall tributary than in the confluence braided stream and Beaver Pond 2 where biogeochemical conditions are more suited to mercury methylation. Mercury concentrations in composites of these fish were elevated at all Tims Branch sites with respect to the reference site (D1 pond). 


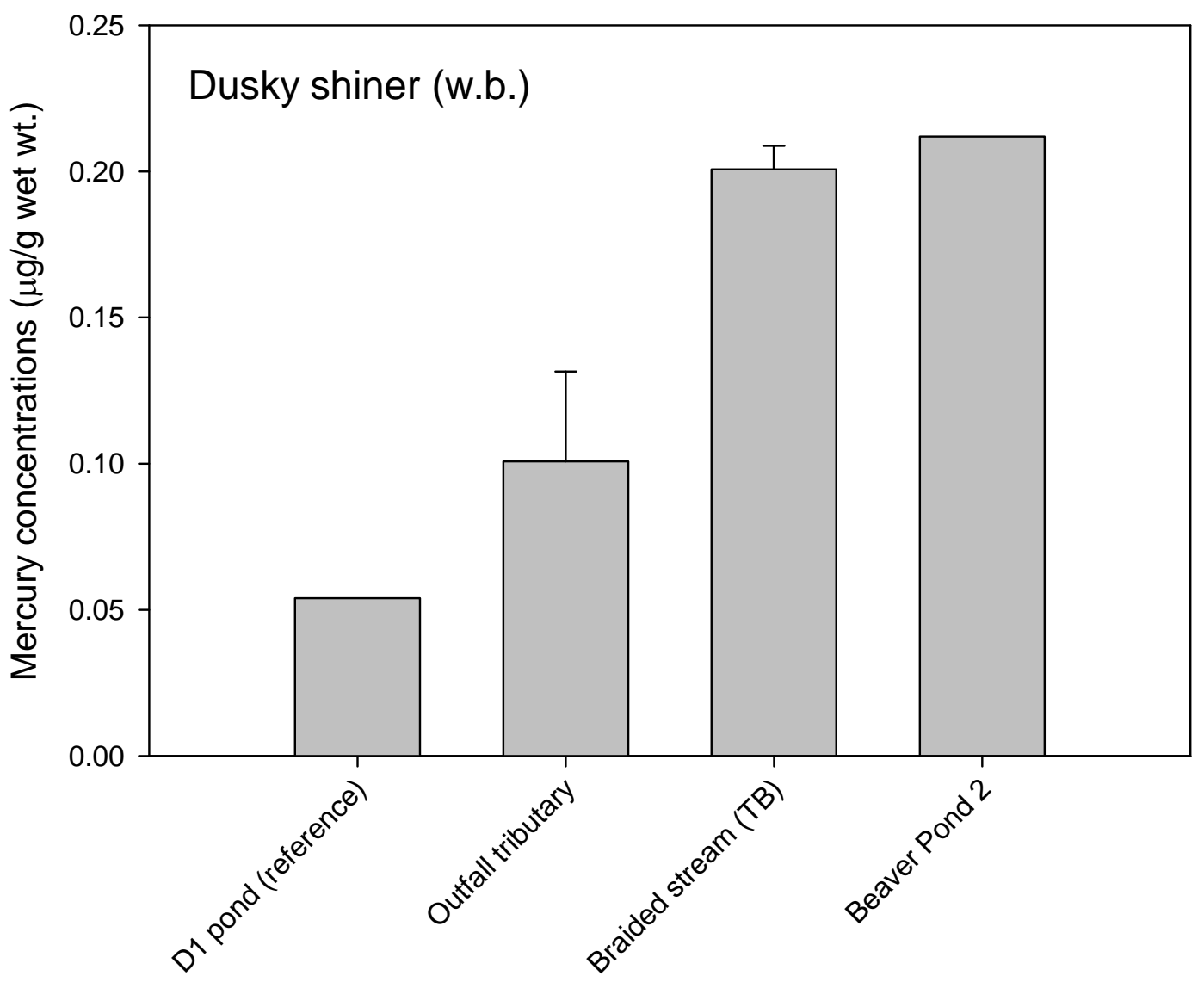

Figure 16. Mercury concentrations in whole body (w.b.) composites of Dusky shiners collected from various sites in the Tims Branch (TB) watershed and a reference site in November 2011 (post treatment).

Bars represent the means of 3 replicate samples collected from each site, and error bars represent 1 standard error. Note these concentrations are on a w.w. basis

The 2011 fillet mercury concentrations in redfin pickerel (Figure 17) show the same trend-elevated concentrations at all Tims Branch sites with respect to the D1 pond reference site. Mercury concentrations in fillets of pickerel were below EPA's AWQC basis concentration ( $0.3 \mu \mathrm{g} / \mathrm{g} \mathrm{w} . \mathrm{w}$. fillet) at the reference site and in the outfall tributary, but exceeded this criterion in the confluence braided stream and in Beaver Pond 2. The measured Beaver Pond 22011 fillet concentrations ( $\cong 0.45 \mu \mathrm{g} / \mathrm{g} \mathrm{w} . \mathrm{w}$. fillet) are similar to the 2010 fillet concentrations estimated from w.b. data ( $\cong 0.36 \mu \mathrm{g} / \mathrm{g} \mathrm{w} . \mathrm{w}$. fillet).

Future reports will relate mercury and tin concentrations in fillets to whole body concentrations, as well as with other tissue types. Future reports will also examine mercury and tin bioaccumulation in invertebrates collected in the outfall tributary and the tin impacted portions of Tims Branch. 


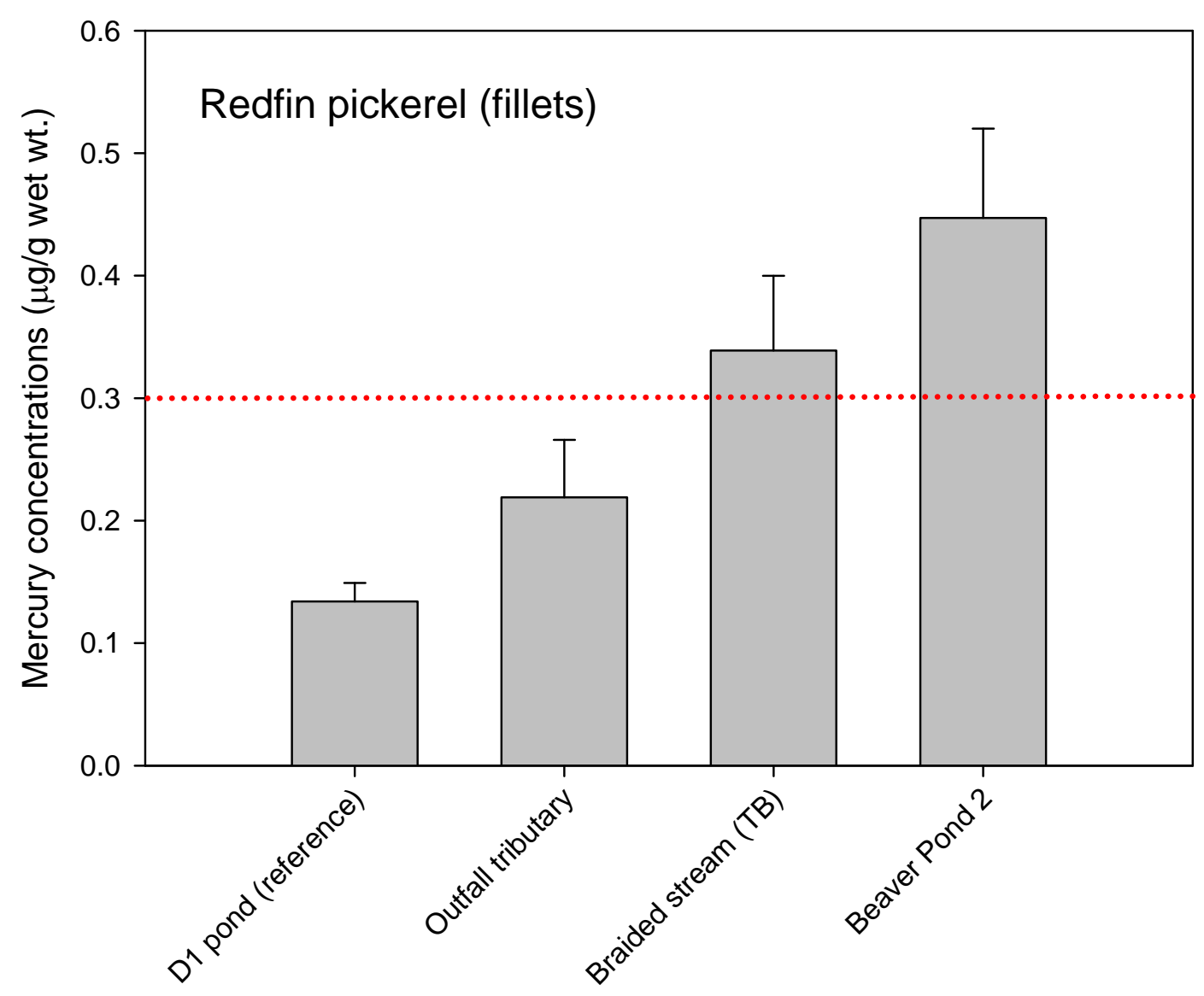

Figure 17. Mercury concentrations in fillets of redfin pickerel collected from various sites in the Tims Branch (TB) watershed and a reference site in November 2011 (post treatment).

Bars represent the means of 3-8 replicate samples collected from each site, and error bars represent 1 standard error. Dotted red line depicts EPA's guideline for $\mathrm{Hg}$ in fillet ( $0.3 \mu \mathrm{g} / \mathrm{g}$ wet wt.)

\section{Conclusions}

While some analytical results are still currently pending, this interim report shows clear evidence of a decrease in mercury concentrations in water and biota throughout the Tims Branch watershed after the stannous chloride treatment system was implemented. Mercury discharges to Tims Branch from the M Area outfall tributary in 2010/2011 are approximately 80\% to 90\% lower than 2006 levels. In Beaver Pond 2, the site with the highest measured mercury concentrations in biota, the mercury levels in 2010 w.b. fish were approximately 72\% lower than 2006 levels. Fillet mercury concentrations in 2011 in the outfall tributary closest to the treatment system were below EPA's guidelines for mercury in fish. Geochemical characterization of the different compartments of the watershed show that tin does not persist in the water column, but tends to precipitate and accumulate in the sediment and biofilm within approximately $3 \mathrm{~km}$ of the discharge location. Future results will provide insight as to the potential impacts of exposure to elevated tin concentrations and will be relevant to a complete assessment of the net impacts of stannous chloride treatment in stream systems. 


\section{References}

Agency for Toxic Substances and Disease Registry (ATSDR), 2005. Public Health Statement: Tin and Tin Compounds, Department of Health and Human Services, Public Health Service, Washington DC. August 2005. available from www.atsdr.cdc.gov .

Amouroux, D., E. Tessier and O. X. Donard, 2000. Volatilization of organotin compounds from esturine coastal environments, Environmental Science and Technology, 34:988-995.

Becker, D.S. and G.H. Bigham, 1995. Distribution of mercury in the aquatic food web of Onondaga Lake, New York. Water Air and Soil Pollution, 80:563-571.

Betancourt and B.B. Looney, 2011. Tin Distribution and Fate in Tims Branch at the Savannah River Site, DOE-FIU Science and Technology Workforce Development Initiative, Summer 2011 Internship Technical Report, Applied Research Center, Florida International University, Miami FL (available at: $\underline{w w w . a r c . f i u . e d u}$ ).

Bethke, C.M.and S. Yeakel, 2009. The Geochemist's Workbench® (geochemical modeling software), Release 8.0 Reference Manual, University of Illinois.

Braman, R. S. and M. A. Tompkins, 1979. Separation and determination of nanogram amounts of inorganic tin and methyltin compounds in the environment. Analytical Chemistry, 51:12-19.

Brigham, M.E., D.A. Wentz, G.R. Aiken and D.P Krabbenhoft, 2009. Mercury cycling in stream ecosystems. 1. water column chemistry and transport, Env. Sci. Tech., 43:27202725.

Celo, V., D.R.S. Lean andd S.L. Scott. 2006. Abiotic methylation of mercury in the aquatic environment. Science of the Total Environment 368:126-137.

Chasar LC, Scudder BC, Stewart AR, Bell AH, Aiken GR (2009) Mercury cycling in stream ecosystems. 3. Trophic dynamics and methylmercury bioaccumulation. Environmental Science \& Technology 43:2733-2739

Chen, B, Q. Zhou, D. Cao, T. Wang and G. Jiang, 2007. Methylation mechanism of tin (II) by methylcobalamin in aquatic systems. Chemosphere, 68:414-419.

Craig, P. J. and S. Rapsomanikis, 1985. Methylation of tin and lead in the environment: oxidative methyl transfer as a model for environmental reactions, , Environmental Science and Technology, 19:726-730.

Donard, O.F.X. and J.H. Weber. 1985. Behavior of methyltin compounds Under Simulated Estuarine Conditions, Environmental Science and Technology, 19:1104 - 1110.

Driscoll, C.T., J. Holsapple, C.L. Schofield, and R. Munson, 1998. The chemistry and transport of mercury in a small wetland in the Adirondack region of New York, USA, Biogeochemistry, 40: 137-146. 
Environmental Protection Agency (EPA), 2007. Treatment Technologies for Mercury in Soil, Waste, and Water. U.S. Environmental Protection Agency, Office of Superfund Remediation and Technology Innovation, Washington, DC 20460, August 2007.

Environmental Protection Agency (EPA), 2002. ECOTOXicology database (ECOTOX), Office of Research and Development (ORD), and the National Health and Environmental Effects Research Laboratory's (NHEERL's) Mid-Continent Ecology Division. Available at http://www.epa.gov/ecotox .

Environmental Protection Agency (EPA), 2001. Water quality criterion for the protection of human health: Methylmercury. In: Office of Water (ed). U.S. EPA, Washington, DC

Environmental Protection Agency (EPA), 2000. EPA's multimedia strategy for priority persistent, bioaccumulative, and toxic (PBT) pollutants: executive summary, www.epa.gov/pbt

Environmental Protection Agency (EPA), 1999. Method 1631, Revision B, mercury in water by oxidation, purge and trap, and cold vapor atomic fluorescence spectrometry. Rep. No. EPA 821/R-99-005, Washington, D.C.

Environmental Protection Agency (EPA), 1998a, A multimedia strategy for priority persistent, bioaccumulative, and toxic (PBT) pollutants, Federal Register, 63, No. 221: Nov. 17, 63926-63928.

Environmental Protection Agency (EPA), 1998b. Clean water action plan: restoring and protecting America's waters, Rep. No. EPA-840-R-98-001, Washington, D.C.

Environmental Protection Agency (EPA), 1997a. Mercury study report to congress Volume I: executive summary, EPA-452/R-97-003, Washington, D.C.

Environmental Protection Agency (EPA), 1997b. The Great Lakes binational toxics strategy, Canada-United States, strategy for the virtual elimination of persistent toxic substances in the Great Lakes, Binational Executive Committee of Environment Canada and the U.S. Environmental Protection Agency, www.epa.gov/glnpo/bns/ (April 17).

Ericksen, J.A., M.S. Gustin. 2004. Foliar Exchange of Mercury as a function of soil and air mercury concentrations, Sci. Tot. Env. 324: 271-279

Ericksen, J.A., M.S. Gustin, D.E. Schorran, D.W. Johnson, S.E. Lindberg, J.S. Coleman. 2002. Accumulation of atmospheric mercury in forest foliage, Atmospheric Environment, 37: 1613-1622.

Fuchs, S., Haritopoulou, T., Schäfer, M., Wilhelmi, M., 1997. Heavy metals in freshwater ecosystems introduced by urban rainwater runoff -- monitoring of suspended solids, river sediments and biofilms, Water Sci. and Tech., 36:277-282. 
Gilmour, C.C, Tuttle, J.H., and J.C. Means. 1985. Tin methylation in estuarine sediment. in Fate and Effects of Pollutants: A Symposium. College Park, MD April 26-27 1985.

Hallas, L.E. and J. J. Cooney, 1981. Tin and tin-resistant organisms in Chesapeake Bay, Applied and Environmental Microbiology, 41: 466-471.

Halverson, N. V., J. A. Bowers, M. H. Paller, D. G. Jackson, J. K. King and D. L. Dunn, 2008. Final Report on the Aquatic Mercury Assessment Study, SRNS-STI- 2008-00106, US Department of Energy Office of Scientific and Technical Information, Oak Ridge TN.

Hamasaki, T,, H. Nagase, Y. Yoshioka, and T. Sato. 1995. Formation, distribution, and ecotoxicology of methylmetals of tin, merccury, and arsenic in the environment. Critical Reviews in Environmental Science and Technology. 25: 45 - 91.

Hatch, W. R., and Ott, W. L., 1968. Determination of sub-microgram quantities of mercury by atomic absorption spectrophotometry. AnalyticalChemistry, 40:2085-2087.

Hintelmann, H., R. Harris, A. Heyes, J.P. Hurley, C.A. Kelly, D.P. Krabbenhoft, S. Lindberg, J.W.M. Rudd, K.J.Scott, V.L. St. Louis. 2002. Reactivity and mobility of new and old mercury deposition in a boreal forest ecosystem during the first year of the METAALICUS Study, Env. Sci. Tech., 36: 23.

Jackson, D. G., B. B. Looney, M. C. Thompson, T. F. Kmetz and J. J. Kupar, 2008. Removal of mercury in groundwater via chemical reduction, Proceedings of the Sixth International Conference on Remediation of Chlorinated and Recalcitrant Organics, Monterey CA, May 2008. available from Battelle Conference Group, Columbus OH.

Jackson, J. A., W. R. Blair, F. E. Brinkman, and W. P. Iverson, 1982. Gaschromatographic speciation of methyl stannanes in the Chesapeake Bay using purga and trap sampling with a tin specific detector. Environmental Science and Technology, 16:110-119.

Joslin JD, 1994. Regional differences in mercury levels in aquatic ecosystems- a discussion of possible causal factors with implications for the Tennessee river system and the northern hemisphere. Environ Manage 18:559-567

Krabbenhoft, D.P., J.G. Wiener, W.G. Brumbaugh, M.L. Olson, J.F. DeWild, and T.J. Sabin, 1998. A National Pilot Study of Mercury Contamination of Aquatic Ecosystems along Multiple Gradients, US Geological Survey Project Report.

Landis, M.S., G.J. Keeler. 2002. Atmospheric mercury deposition to Lake Michigan during the Lake Michigan mass balance study, Env. Sci. Tech., 36:21.

Lindberg, S.E., W. Dong, T. Tilden Meyers. 2002. Transpiration of gaseous elemental mercury through vegetation in a subtropical wetland in Florida. Atmospheric Environment 36: 5207-5219. 
Looney, B.B., D.G. Jackson, M.J. Peterson, T.J. Mathews, G. Southworth, L. Bryan, M. Paller, C.A. Eddy-Dilek, and N. Halverson, 2010. Assessing Potential Impacts of Stannous Chloride Based Mercury Treatment on a Receiving Stream Using Real-World Data from Tims Branch, Savannah River Site, SRNL-STI-2010-00393, available from the US Department of Energy Office of Scientific and Technical Information, Oak Riddge TN (www.osti.gov).

Looney, B. B., M. E. Denham, K. M. Vangelas, and N. S. Bloom. 2003a. Removal of mercury from low-concentration aqueous streams using chemical reduction and air stripping, Jour. of Env. Eng., 129:819-825.

Looney, B. B., P. B. Bertsch, and G. G. Geesey, 2003b. Research Opportunities for Studies of Contaminant Transport in Fluvial Systems at the Tims Branch - Steed Pond System, Savannah River Site, WSRC-TR-2003-00312, U.S. Department of Energy Office of Scientific and Technical Information, Oak Ridge TN.

Looney, B. B., C. A. Eddy-Dilek, R. Turner, G. Southworth, M. Peterson, A. Polumbo, 2008. Recommendations to Address Technical Uncertainties in the Mitigation and Remediation of Mercury Contamination at the Y-12 Plant, Oak Ridge, Tennessee, WSRC-STI-2008-00212, U.S. Department of Energy Office of Scientific and Technical Information, Oak Ridge TN.

Mason, R.P, J.-M. Laporte and S. Andres, 2000. Factors controlling the bioaccumulation of mercury, methylmercury, arsenic, selenium, and cadmium by freshwater invertebrates and fish. Arch Env. Cont. Tox., 38: 283-297.

Nelson, E. A. and J. B. Gladden, 2007. Full-Scale Treatment Wetlands for Metal Removal from Industrial Wastewater, WSRC-MS-2007-00058, U.S. Department of Energy Office of Scientific and Technical Information, Oak Ridge TN.

Orihel, D.M, M.J. Paterson, P.J. Blanchfield, R.A. Rodaly and H. Hintelmann, 2007. Experimental evidence of a linear relationship between inorganic mercury loading and methylmercury accumulation by aquatic biota, Env. Sci. Tech., 41:4952-4958.

Peterson, M.J., BB. Looney, G. Southworth, C.A. Eddy-Dilek, D. Watson, R. Ketelle and M.A. Bogle, 2011. Conceptual Model of Primary Mercury Sources, Transport Pathways, and Flux at the Y-12 Complex and Upper East Fork Poplar Creek, Oak Ridge, Tennessee, ORNL/TM-2011/75, U.S. Department of Energy Office of Scientific and Technical Information, Oak Ridge TN (available at: www.osti.gov ).

Peterson, S.A., J. Van Sickle, R.M. Hughes, J.A. Schacher and S.F. Echols, 2005. A biopsy procedure for determining filet and predicting whole-fish mercury concentration, Arch. of Environ. Contam. and Tox., 48:99-107.

Pickett, J. B. 1990. Heavy Metal Contamination in Tims Branch Sediments, Report OPSRMT- 90-900200. Westinghouse Savannah River Company, Aiken, SC. 
Rapsomanikis, S and J. H. Weber, 1985. Environmental implications of methylation of tin(II) and methyltin(IV) ions in the presence of manganese dioxide, Environmental Science and Technology, 19:352-356.

Ridley, W. P., L. J. Dizikes and J. M. Wood, 1977. Biomethylation of toxic elements in the environment, Science, 197:329-332.

Roy, V., M. Amyot, and R. Carigan, 2009a. Beaver ponds increase methylmercury concentrations in canadian shield streams along vegetation and pond-age gradients, Env. Sci. Tech., 43:5605-5611.

Roy, V., M. Amyot, and R. Carigan, 2009b. Seasonal methylmercury dynamics in water draining three beaver impoundments of varying age, J. Geophys. Res., 114:G00C06.

Ristić, M. M. Ivanda, S. Popović, S. Musić, 2002. Dependence of nanocrystalline $\mathrm{SnO} 2$ particlesize on synthesis route, Journal of Non-Crystalline Solids, 303:270-280.

Southworth GR, Peterson MJ, Roy W, Mathews T, 2011. Monitoring fish contaminant responses to abatement actions: Factors that affect recovery, Environ. Mgmt. 47:10641076

Southworth, G. R., M. A. Bogle, S. Brooks, L. Liang, M. Peterson, B. Spalding, D. Watson, F. Zhang, T. J. Abraham. 2010. Evaluation of new options for reducing mercury release at the Y-12 National Security Complex. Report No. ORNL/TM-2010/33, U.S. Department of Energy

Southworth, G. R., S. C. Brooks, M. J. Peterson, M. A. Bogle, C. L. Miller, L. Liang, M. Elliot. 2009. Controlling mercury release from source zones to surface water: initial results of pilot tests at the Y-12 National Security Complex. Report No. ORNL/TM2009/035, U.S. Department of Energy. Oak Ridge Operations Office, Oak Ridge TN.

Southworth, G., 1997. Proposed experiment for SnCl treatment of Outfall 200 for the purpose of mercury removal from East Fork Poplar Creek Y-12 Plant, Oak Ridge TN. Report No. Y/TS-1663, U.S. Department of Energy, Oak Ridge Operations Office, Oak Ridge TN.

Southworth, G., 1996. Mercury abatement report on the U.S. Department of Energy's Oak Ridge Y-12 plant for the fiscal year 1996. Report No. Y/ER-277, U.S. Department of Energy, Oak Ridge Operations Office, Oak Ridge, Tenn., pp 2-2 through 2-3.

Sonesten, L., 2003. Fish mercury levels in lakes — adjusting for $\mathrm{Hg}$ and fish-size covariation, Env. Pollution, 125:255-265.

Strom, R.N. and D.S. Kaback, 1992. SRP Baseline Hydrogeologic Investigation: Aquifer Characterization (Groundwater Geochemistry of the Savannah River Site and Vicinity), WSRC-RP-92-450, US Department of Energy Office of Scientific and Technical Information, Oak Ridge TN. 
Sveinsdottir AY, Mason RP, 2005. Factors controlling mercury and methylmercury concentrations in largemouth bass (micropterus salmoides) and other fish from maryland reservoirs., Arch. Environ. Contam. Toxicol. 49:528-545

Thompson, M. and R.J. Howarth, 1973. The rapid estimation of control and precision by duplicate determinations, Analyst, 98:153-160.

Turner RR, Southworth GR, 1999. Mercury-contaminated industrial and mining sites in north america: An overview with selected case studies. In: Ebinghaus R, Turner RR, De Lacerda L, Vasiliev O, Salomons W (eds) Mercury contaminated sites. Springer-Verlag, Berlin

Ward DM, Nislow KH, Folt CL, 2010. Bioaccumulation syndrome: Identifying factors that make some stream food webs prone to elevated mercury bioaccumulation. In: Year in ecology and conservation biology 2010, Vol 1195. Blackwell Publishing, Oxford, p 62-83 


\section{Appendix A}

\section{Graph of Mercury Concentrations Entering Tims Branch (with Extended Annotation)}

Figure A provides quantitative information about the recent releases of mercury to the Tims Branch system. This figure extends the information provided in Figure 4 in the main body of the report. The original data has been annotated by overlaying the concentration of mercury being transferred in batches of wastewater from the DUS (thermal steam remediation) system, a supplemental soil/groundwater treatment that was used to flush chlorinated solvents and associated co-contaminants, such as mercury, from the subsurface beneath the former $\mathrm{M}$ Area Settling Basin. The high concentration of mercury in this wastewater increased mercury concentration at the former A11 outfall between 2005 and 2007. The overlay graph is scaled so that the y axis is approximately coincident with baseline concentrations and so that the relative scale of the peaks are similar in magnitude to the stream data at the former A11 outfall. As shown, the pattern of peaks and valleys in the mercury measurements at the former A11 outfall closely track the pattern of mercury concentration in water being transferred from the DUS system. After initiation of the stannous chloride treatment system in November 2007, the concentrations of mercury in the DUS batch transfers generally increased (between 2007 and 2011). The resulting increases are not observed in the stream water of the M Area outfall tributary, however, because the mercury was effectively removed in the air stripper.

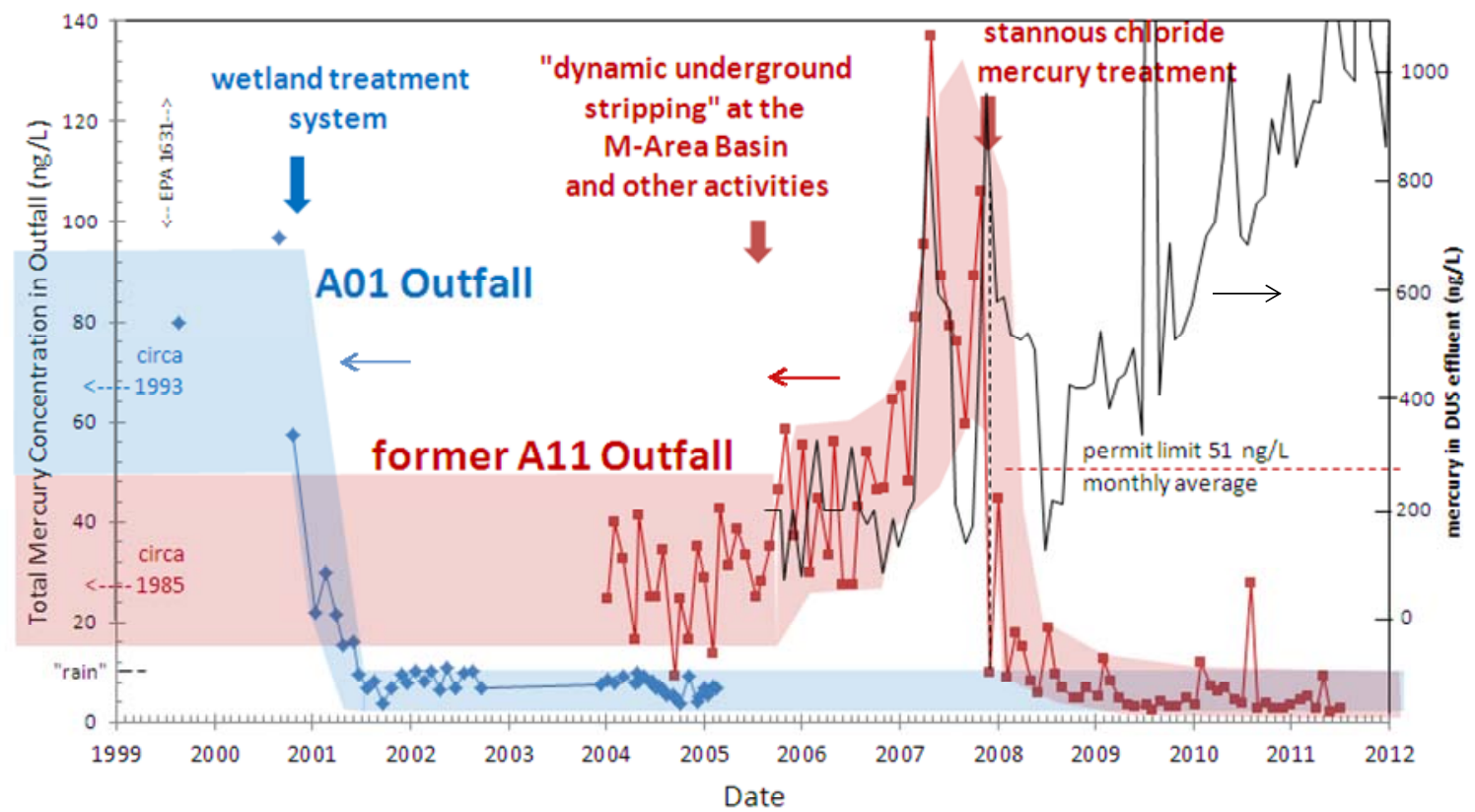

Figure A. Annotated graph of the concentrations of mercury measured at the A01 outfall (blue) and A11 outfall (red) with a scaled overlay of mercury concentrations in batch transfers of wastewater from the DUS system (black line) 


\section{Appendix B}

\section{Example Quality Assurance Information}

\section{Introduction}

For all analyses certified standards were used for instrument calibration and instrument checking. Duplicates/blanks were run with each batch of samples. For solid matrices such as sediment, biofilm and biota, certified reference standards were run regularly to assure quality. Two examples of the QA protocols are provided below.

\section{Example QA Information for 2010 Whole Body Fish/Biota Analysis}

Mercury analysis of 2010 whole body fish samples (analyzed using the Milestone DMA80 direct mercury analyzer), two certified standards, a duplicate and two blanks were run with each set of 10 samples. The instrument was calibrated using certified reference tissue samples from the National Research Council of Canada, TORT-2 $(0.27 \mu \mathrm{g} / \mathrm{g})$ and DOLT-4 $(2.58 \mu \mathrm{g} / \mathrm{g})$. As shown in Figure B1, the calibration included fourteen points five in the low range ( 0 to $20 \mathrm{ng}$ ) and nine in the high range ( $>20$ to $500 \mathrm{ng})$. The $\mathrm{r}^{2}$ value for the calibration was 0.9999 in the low range and 1.0000 in the high range.

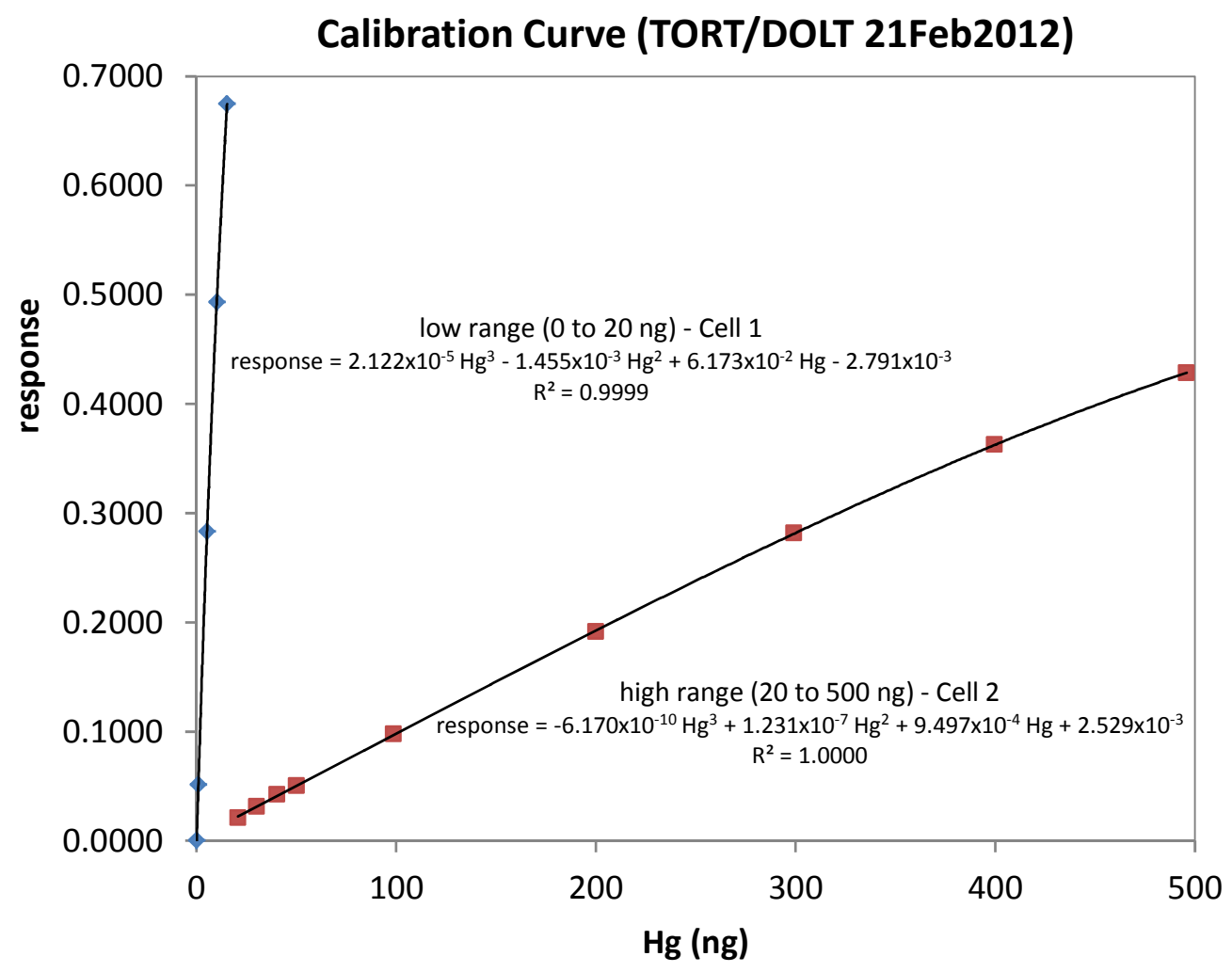

Figure B1. Calibration curve for mercury analysis at SREL using the Milestone DMA-80 whole body fish and biota, 2010 samples. 
This calibration was used throughout analyses for 2010 biota samples and was verified by analyzing two certified standards (TORT-2 and DOLT-4) with each 10 unknown samples. Figure B2 provides information on the sequential measurements over the course of the work. This control chart demonstrates the accuracy and reproducibility of the analyses. The measured values cluster tightly around the reference values. The approximate ranges for the calibration and field data are annotated on the chart. The practical quantitation limit, $0.03 \mu \mathrm{g} / \mathrm{g}$, is the $95 \%$ upper confidence interval for the 28 blanks analyzed. Freeze dried bird eggs (Least Tern) and Tims Branch fish were analyzed during this timeframe.

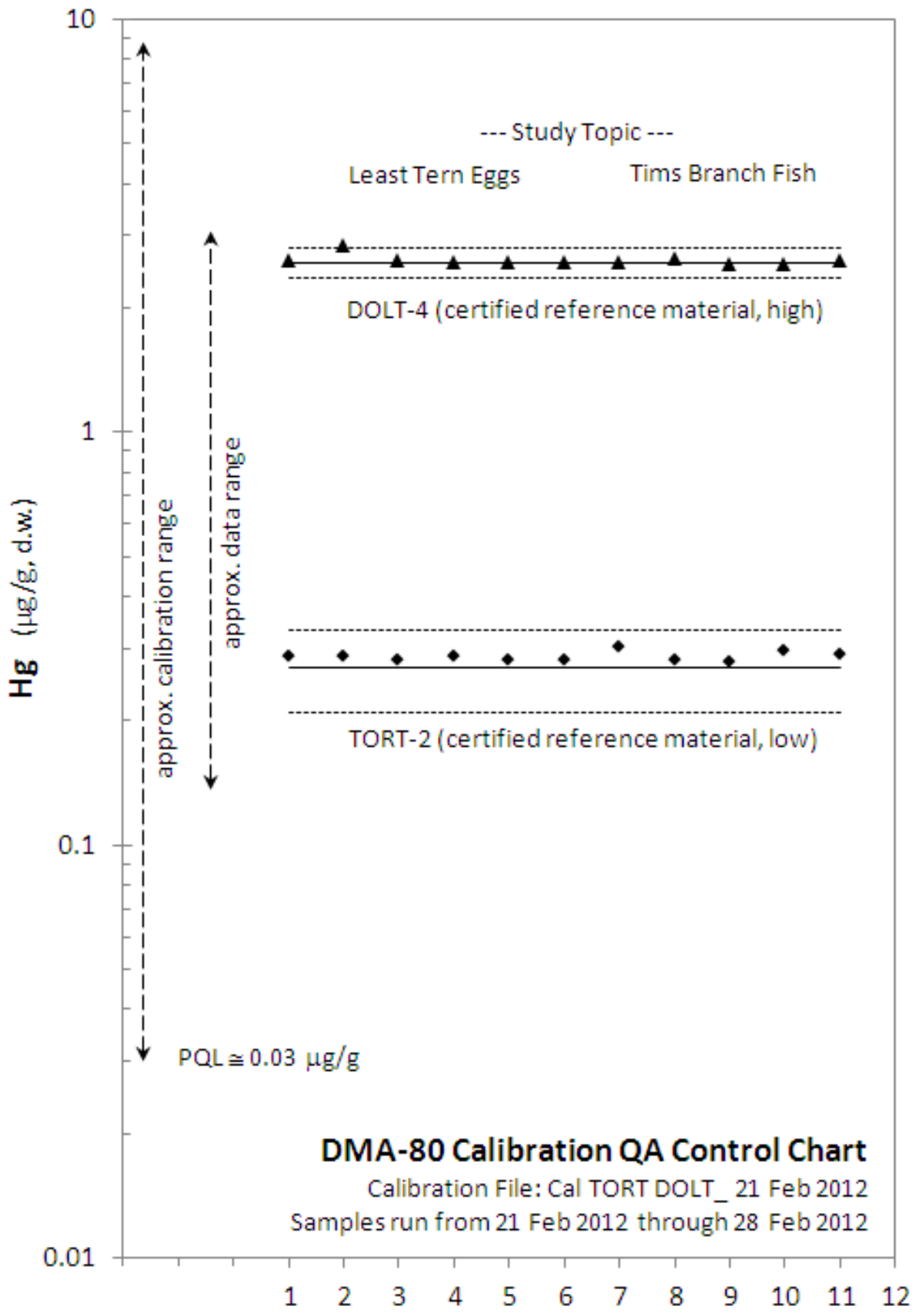

Figure B3. QA control chart for analysis of mercury in 2010 samples of whole body fish and biota 


\section{Example QA information for Tin Analysis in Sediment and Biofilm}

Sediment and biofilm samples collected in 2011 were analyzed using a Niton XL3t GOLDD+ analyzer in the Test All Geo mode. A site specific tin calibration standard was gravimetrically prepared by spiking inorganic tin into uncontaminated stream sediment collected from a control stream. The relationship between the instrument response and the reference concentration in the standards was used to develop a calibration equation. All of the reported tin concentrations in this report were generated using the site-specific calibration. The relationship between the estimated and reference concentrations for the standards is depicted in Figure B4. Additional information on the instrument conditions and calibration are provided in Betancourt and Looney (2011).

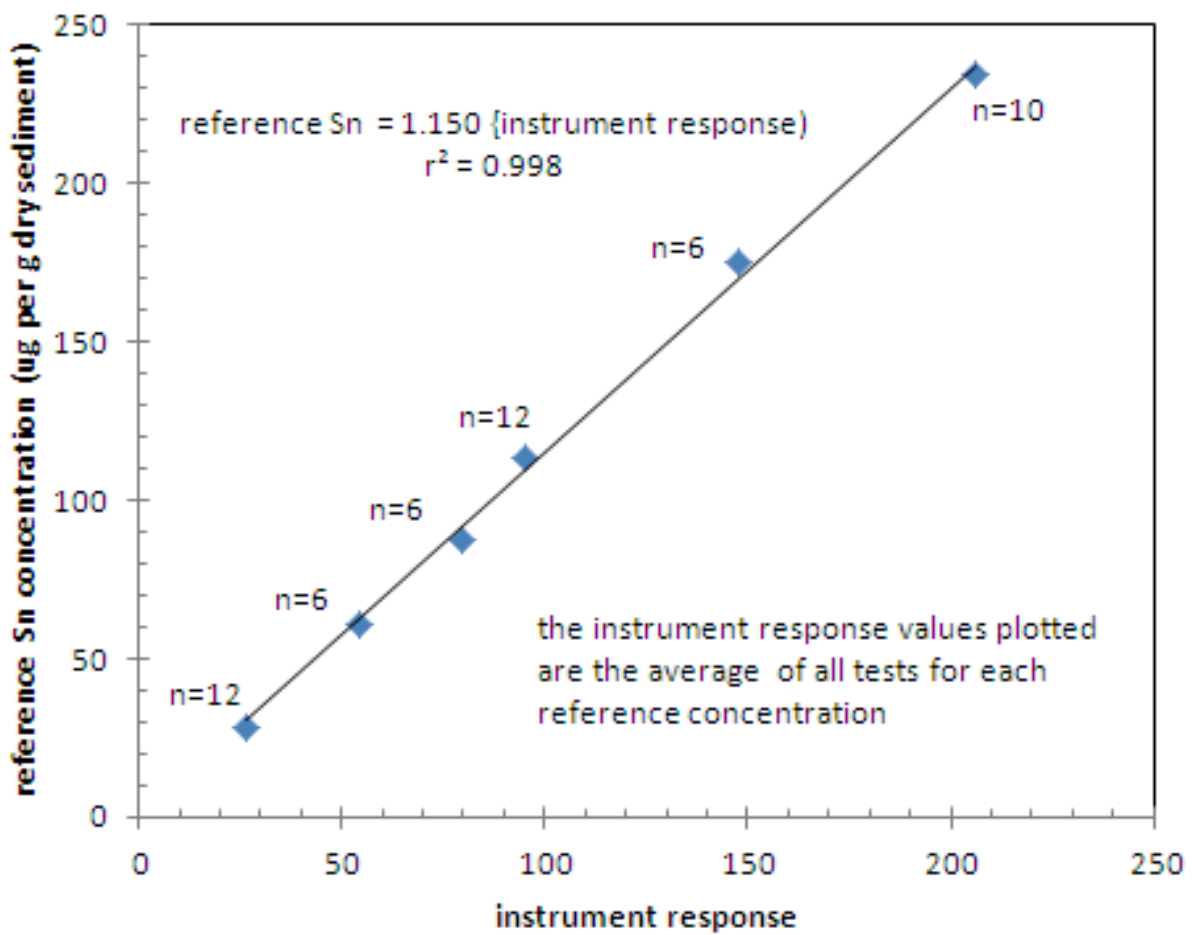

Figure B4. Calibration curve for tin analyzed with the Thermo Scientific Niton XL3t GOLDD+ XRay Fluorescence (XRF) Spectrophotometer.

The relative standard deviation (RSD) is a method of approximating the standard deviations of multiple samples over a range of concentrations. For this study, the RSD for tin was estimated in two ways: 1 ) based on multiple runs ( $n=6$ to 12 ) of the five reference standards, and 2) based on the differences observed in duplicate measurements for all of the Tims Branch samples and standards. The first method used to calculate the RSD for tin used the results of frequent analyses of five reference standards. The bias corrected standard deviation (sigma, or $\sigma$ ) was calculated for each concentration. The RSD is then defined as the following linear equation: $\sigma_{\text {concentration }}=(\mathrm{RSD})($ concentration $)$. Therefore, in Figure B5, the slope of the trendline of concentration versus the standard deviation, approximately 0.16 , is an estimate of the RSD based on the 26 duplicate ( 52 total) measurements of reference standards. 


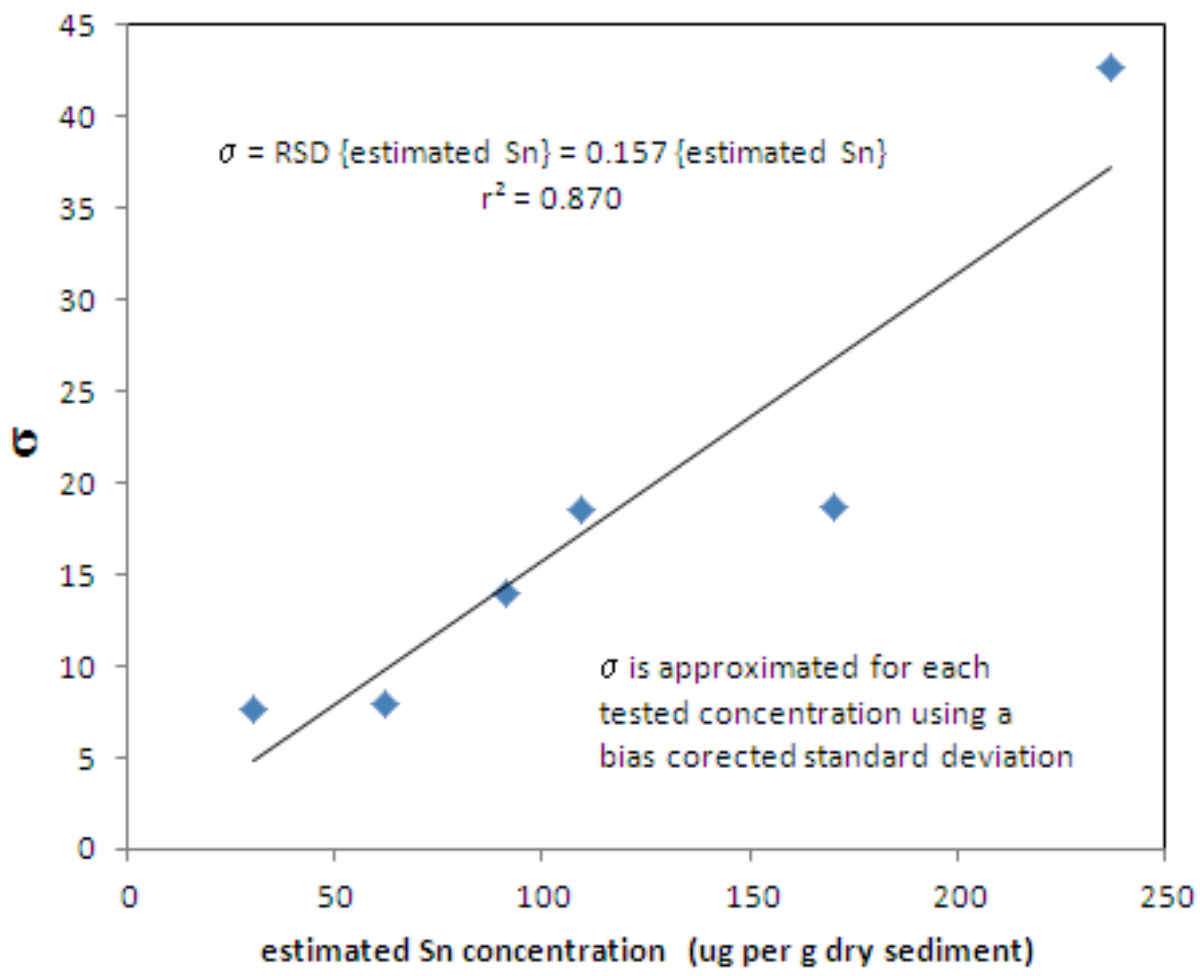

Figure B5. Plot of the estimated tin concentration versus the standard deviation for each reference standard.

Since all samples were analyzed in duplicate, a separate estimate of RSD is possible (see Thompson and Howarth 1973 for a discussion of the methods to develop RSD from a dataset of duplicates). For tin, 93 of the 225 duplicates analyzed were above the detection limit. The available duplicates included the prepared tin standards, standard reference materials from the United States National Institute of Standards and Technology (NIST), specifically NIST reference standard 2702 marine sediments, and many of the unknown sediment samples collected along Tims Branch. The RSD for tin based on the 93 duplicates was 0.18 , which is similar to the 0.16 estimated using only the analyses of the reference standards. RSD values in the range of 0.16 to 0.18 are typical for xrf analyses of dry unconsolidated samples.

To document that the analysis was in control, the reference NIST 2702 sample was analyzed daily. Figure B6 provides information on the sequential measurements over the course of the work. This control chart demonstrates the accuracy and reproducibility of the analyses. The measured values cluster around the reference value with variability consistent with the calculated RSD above. 


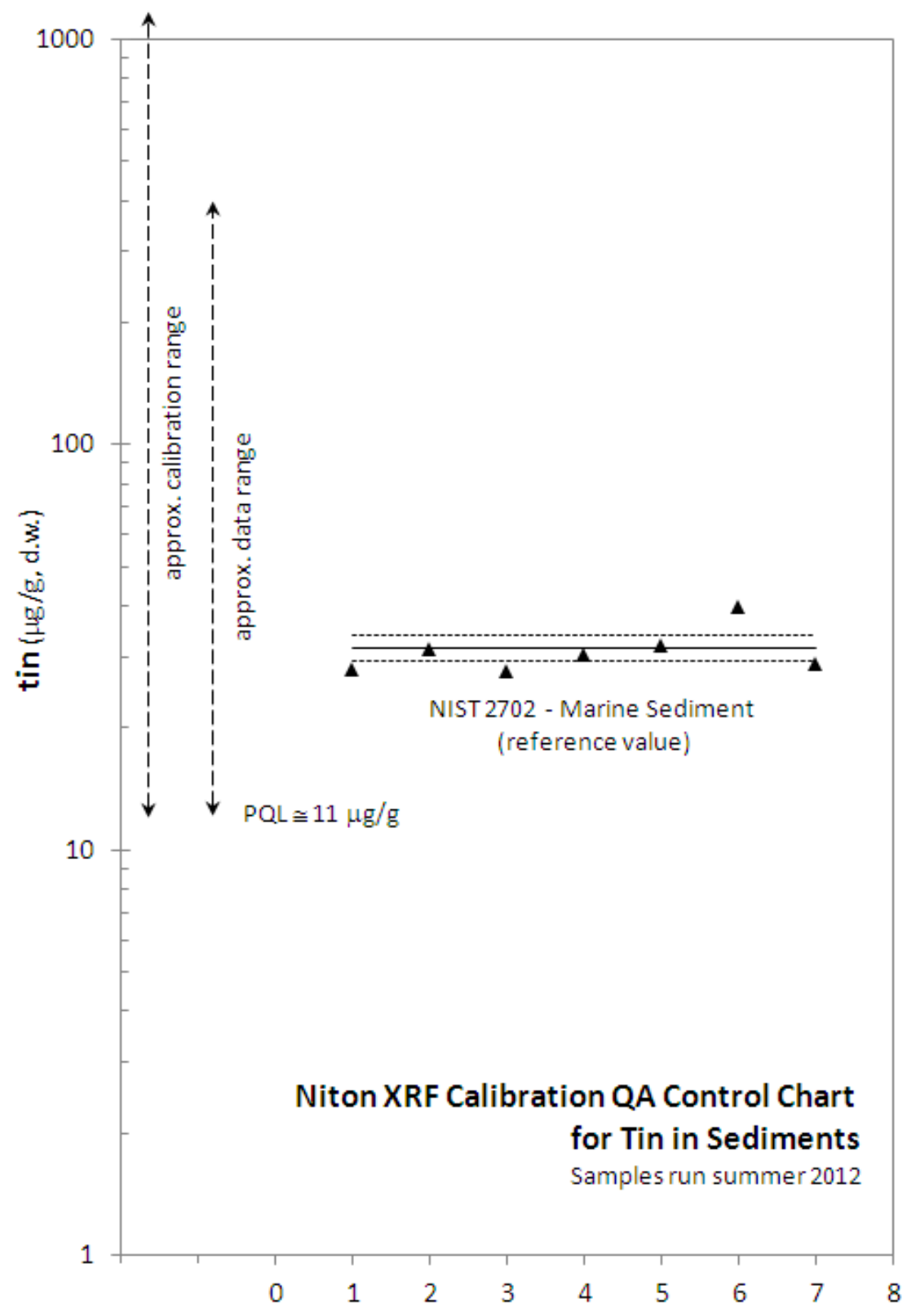

Figure B6. QA control chart for analysis of tin in sediment and biofilm 


\section{Appendix C}

\section{Tabulated Information on Whole Body Fish Samples for Tims Branch (2006 and 2010)}

The following data tables provide detailed information on the subject fish/biota. Table $\mathrm{C} 1$ excerpts the data for redfin pickerel in Pond 1 (control) and in Beaver Ponds 1-4.

The remaining tables provide a complete dataset for mercury in all 625 Tims Branch fish analyzed in 2006 and 2010 (all species and all locations). In 2010, 55 fish were analyzed (39 redfin pickerel and 16 sunfish sp.), all from pond environments along Tims Branch. In 2006, 570 fish were analyzed (diverse species) and samples were collected from ponds and from several stream reaches. 
SRNL-STI-2012-00202

Table C1. Excerpted Redfin Pickerel Data Used in Analysis Mercury data for redfin pickerel in Tims Branch (2006 and 2010)

\begin{tabular}{|c|c|c|c|}
\hline \multicolumn{4}{|l|}{ Control Pond 1} \\
\hline \multicolumn{2}{|c|}{2006} & \multicolumn{2}{|c|}{2010} \\
\hline length (mm) & mercury (ug/g, w.b., d.w.) & length (mm) & mercury (ug/g, w.b., d.w.) \\
\hline 109 & 0.336 & 79 & 0.226 \\
\hline 112 & 0.317 & 89 & 0.277 \\
\hline 115 & 0.309 & 89 & 0.224 \\
\hline 116 & 0.400 & 92 & 0.276 \\
\hline 118 & 0.405 & 93 & 0.215 \\
\hline 124 & 0.275 & 101 & 0.215 \\
\hline 126 & 1.055 & 103 & 0.269 \\
\hline 127 & 0.738 & 143 & 0.437 \\
\hline 131 & 1.208 & 157 & 0.277 \\
\hline 134 & 0.418 & 169 & 0.829 \\
\hline 146 & 0.814 & & \\
\hline 159 & 0.884 & & \\
\hline 161 & 0.509 & & \\
\hline 226 & 0.613 & & \\
\hline 235 & 0.414 & & \\
\hline \multicolumn{4}{|l|}{ Beaver Pond 2} \\
\hline \multicolumn{2}{|c|}{2006} & \multicolumn{2}{|c|}{2010} \\
\hline length $(\mathrm{mm})$ & mercury (ug/g, w.b., d.w.) & length (mm) & mercury (ug/g, w.b., d.w.) \\
\hline & & & \\
\hline 116 & 1.495 & 126 & 1.670 \\
\hline 132 & 2.888 & 128 & 0.335 \\
\hline 138 & 2.239 & 151 & 1.042 \\
\hline 140 & 5.088 & 160 & 1.240 \\
\hline 143 & 3.143 & 161 & 1.050 \\
\hline 144 & 3.783 & 165 & 1.268 \\
\hline 148 & 3.313 & 166 & 1.529 \\
\hline 157 & 3.472 & 167 & 0.575 \\
\hline 168 & 2.895 & & \\
\hline 179 & 7.335 & & \\
\hline 183 & 5.142 & & \\
\hline \multicolumn{4}{|l|}{ Beaver Pond 3} \\
\hline \multicolumn{2}{|c|}{2006} & \multicolumn{2}{|c|}{2010} \\
\hline length (mm) & mercury (ug/g, w.b., d.w.) & length (mm) & mercury (ug/g, w.b., d.w.) \\
\hline 101 & 0.680 & 118 & 0.554 \\
\hline 104 & 0.754 & 129 & 0.592 \\
\hline 104 & 1.473 & 131 & 0.580 \\
\hline 104 & 1.912 & 132 & 0.640 \\
\hline 105 & 2.369 & 133 & 0.626 \\
\hline 107 & 3.123 & 140 & 1.186 \\
\hline 162 & 3.329 & 143 & 0.352 \\
\hline 181 & 4.015 & 144 & 1.765 \\
\hline 204 & 5.283 & 146 & 0.728 \\
\hline 265 & 7.218 & 152 & 1.093 \\
\hline \multicolumn{4}{|l|}{ Beaver Pond 4} \\
\hline \multicolumn{2}{|c|}{2006} & \multicolumn{2}{|c|}{2010} \\
\hline length (mm) & mercury (ug/g, w.b., d.w.) & length (mm) & mercury (ug/g, w.b., d.w.) \\
\hline 76 & 0.537 & 63 & 0.329 \\
\hline 79 & 0.710 & 65 & 0.483 \\
\hline 98 & 0.625 & 123 & 0.498 \\
\hline 154 & 1.847 & 140 & 0.646 \\
\hline 161 & 1.317 & 147 & 0.610 \\
\hline 161 & 1.186 & 166 & 0.985 \\
\hline 164 & 1.966 & 180 & 0.901 \\
\hline 168 & 1.457 & 200 & 2.121 \\
\hline 169 & 1.878 & 244 & 2.490 \\
\hline 170 & 1.787 & & \\
\hline 185 & 1.344 & & \\
\hline 216 & 2.180 & & \\
\hline
\end{tabular}


The following Tables provide the length $(\mathrm{mm})$ and whole body mercury concentrations ( $\mu \mathrm{g} / \mathrm{g}$ dry weight) for fish collected from Tims Branch in 2010 and 2006.

Data are sorted by year, location and species.

Location specifies habitat type (BP-beaver pond vs SR-stream reach) along the Tims Branch gradient (see map below).

Stream reaches above and below each beaver pond was sampled in 2006.

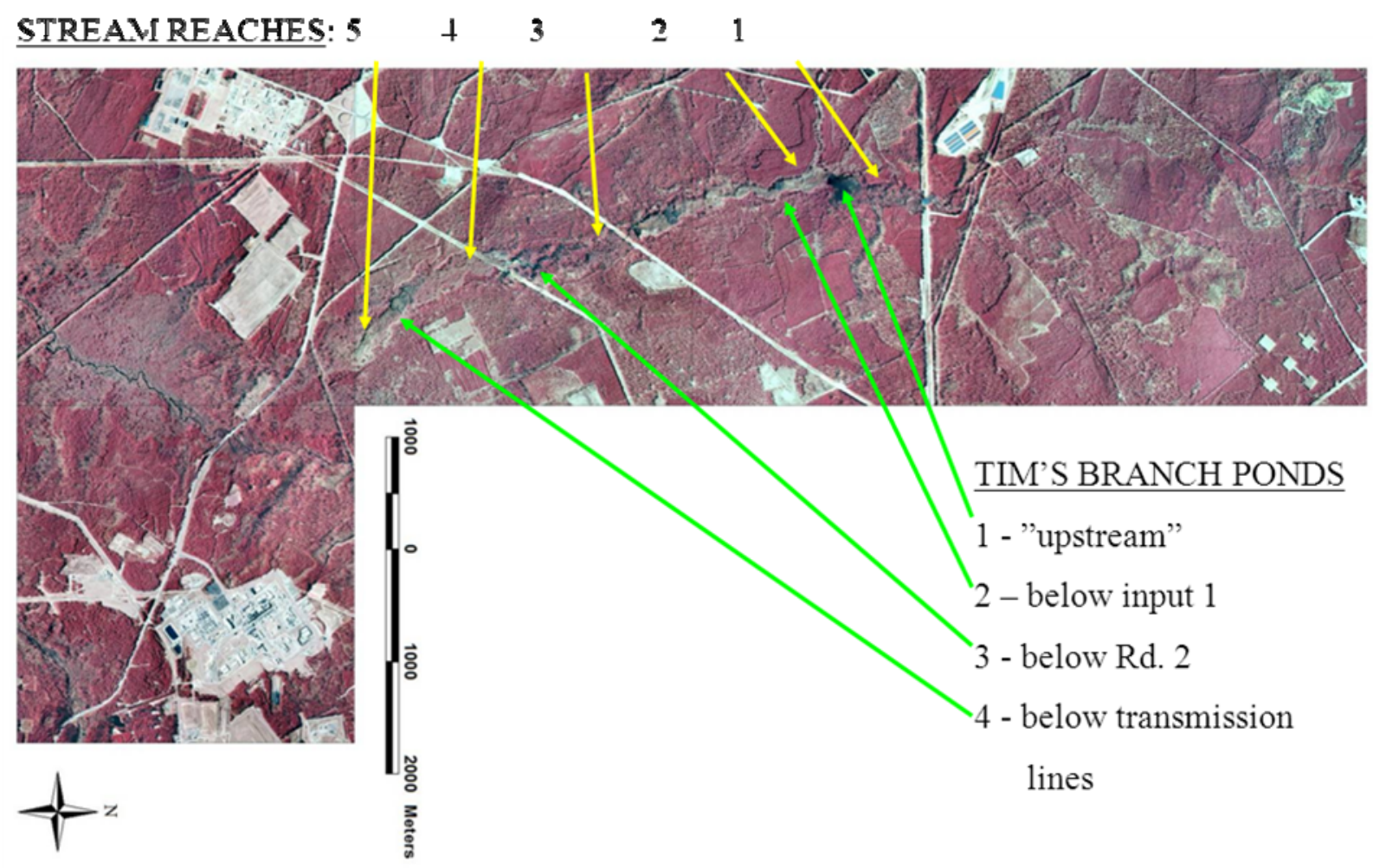




\begin{tabular}{|c|c|c|c|c|c|}
\hline Year & Habitat & Site\# & Species & TL (mm) & Hg (ppm dry wt) \\
\hline 2010 & $\mathrm{BP}$ & 1 & mud sunfish & 56 & 0.241 \\
\hline 2010 & $\mathrm{BP}$ & 1 & mud sunfish & 54 & 53.50 \\
\hline 2010 & $\mathrm{BP}$ & 1 & mud sunfish & 53 & 0.404 \\
\hline 2010 & $\mathrm{BP}$ & 1 & mud sunfish & 56 & 0.230 \\
\hline 2010 & $\mathrm{BP}$ & 1 & redfin pickerel & 157 & 0.277 \\
\hline 2010 & $\mathrm{BP}$ & 1 & redfin pickerel & 79 & 0.226 \\
\hline 2010 & $\mathrm{BP}$ & 1 & redfin pickerel & 89 & 0.277 \\
\hline 2010 & $\mathrm{BP}$ & 1 & redfin pickerel & 93 & 0.215 \\
\hline 2010 & $\mathrm{BP}$ & 1 & redfin pickerel & 103 & 0.269 \\
\hline 2010 & $\mathrm{BP}$ & 1 & redfin pickerel & 169 & 0.829 \\
\hline 2010 & $\mathrm{BP}$ & 1 & redfin pickerel & 143 & 0.437 \\
\hline 2010 & $\mathrm{BP}$ & 1 & redfin pickerel & 89 & 0.224 \\
\hline 2010 & $\mathrm{BP}$ & 1 & redfin pickerel & 101 & 0.215 \\
\hline 2010 & $\mathrm{BP}$ & 1 & redfin pickerel & 92 & 0.276 \\
\hline 2010 & $\mathrm{BP}$ & 2 & mud sunfish & 71 & 0.931 \\
\hline 2010 & $\mathrm{BP}$ & 2 & redfin pickerel & 128 & 0.335 \\
\hline 2010 & $\mathrm{BP}$ & 2 & redfin pickerel & 165 & 1.27 \\
\hline 2010 & $\mathrm{BP}$ & 2 & redfin pickerel & 167 & 0.575 \\
\hline 2010 & $\mathrm{BP}$ & 2 & redfin pickerel & 161 & 1.050 \\
\hline 2010 & $\mathrm{BP}$ & 2 & redfin pickerel & 160 & 1.24 \\
\hline 2010 & $\mathrm{BP}$ & 2 & redfin pickerel & 151 & 1.04 \\
\hline 2010 & $\mathrm{BP}$ & 2 & redfin pickerel & 166 & 1.53 \\
\hline 2010 & $\mathrm{BP}$ & 2 & redfin pickerel & 126 & 1.67 \\
\hline 2010 & $\mathrm{BP}$ & 2 & dollar sunfish & 65 & 0.673 \\
\hline 2010 & $\mathrm{BP}$ & 2 & dollar sunfish & 72 & 0.937 \\
\hline 2010 & $\mathrm{BP}$ & 2 & dollar sunfish & 67 & 0.575 \\
\hline 2010 & $\mathrm{BP}$ & 2 & dollar sunfish & 100 & 1.06 \\
\hline 2010 & BP & 2 & dollar sunfish & 68 & 0.662 \\
\hline 2010 & $\mathrm{BP}$ & 3 & mud sunfish & 79 & 0.461 \\
\hline 2010 & $\mathrm{BP}$ & 3 & mud sunfish & 77 & 0.445 \\
\hline 2010 & $\mathrm{BP}$ & 3 & mud sunfish & 75 & 0.836 \\
\hline 2010 & $\mathrm{BP}$ & 3 & mud sunfish & 71 & 0.366 \\
\hline 2010 & $\mathrm{BP}$ & 3 & redfin pickerel & 132 & 0.640 \\
\hline 2010 & $\mathrm{BP}$ & 3 & redfin pickerel & 152 & 1.09 \\
\hline 2010 & $\mathrm{BP}$ & 3 & redfin pickerel & 131 & 0.580 \\
\hline 2010 & $\mathrm{BP}$ & 3 & redfin pickerel & 118 & 0.554 \\
\hline 2010 & $\mathrm{BP}$ & 3 & redfin pickerel & 133 & 0.626 \\
\hline 2010 & $\mathrm{BP}$ & 3 & redfin pickerel & 140 & 1.19 \\
\hline 2010 & $\mathrm{BP}$ & 3 & redfin pickerel & 146 & 0.728 \\
\hline 2010 & $\mathrm{BP}$ & 3 & redfin pickerel & 144 & 1.76 \\
\hline
\end{tabular}




\begin{tabular}{|c|c|c|c|c|c|}
\hline Year & Habitat & Site\# & Species & TL (mm) & Hg (ppm dry wt) \\
\hline 2010 & $\mathrm{BP}$ & 3 & redfin pickerel & 143 & 0.352 \\
\hline 2010 & $\mathrm{BP}$ & 3 & redfin pickerel & 129 & 0.592 \\
\hline 2010 & $\mathrm{BP}$ & 4 & mud sunfish & 93 & 0.565 \\
\hline 2010 & $\mathrm{BP}$ & 4 & mud sunfish & 89 & 0.552 \\
\hline 2010 & $\mathrm{BP}$ & 4 & mud sunfish & 55 & 0.442 \\
\hline 2010 & $\mathrm{BP}$ & 4 & mud sunfish & 86 & 0.718 \\
\hline 2010 & $\mathrm{BP}$ & 4 & redfin pickerel & 147 & 0.6100 \\
\hline 2010 & $\mathrm{BP}$ & 4 & redfin pickerel & 123 & 0.498 \\
\hline 2010 & $\mathrm{BP}$ & 4 & redfin pickerel & 63 & 0.329 \\
\hline 2010 & $\mathrm{BP}$ & 4 & redfin pickerel & 65 & 0.483 \\
\hline 2010 & $\mathrm{BP}$ & 4 & redfin pickerel & 166 & 0.985 \\
\hline 2010 & $\mathrm{BP}$ & 4 & redfin pickerel & 140 & 0.646 \\
\hline 2010 & $\mathrm{BP}$ & 4 & redfin pickerel & 180 & 0.901 \\
\hline 2010 & $\mathrm{BP}$ & 4 & redfin pickerel & 244 & 2.4900 \\
\hline 2010 & $\mathrm{BP}$ & 4 & redfin pickerel & 200 & 2.12 \\
\hline 2006 & $\mathrm{BP}$ & 1 & golden shiner & 125 & 0.615 \\
\hline 2006 & $\mathrm{BP}$ & 1 & lake chubsucker & 57 & 0.283 \\
\hline 2006 & $\mathrm{BP}$ & 1 & lake chubsucker & 58 & 0.159 \\
\hline 2006 & $\mathrm{BP}$ & 1 & lake chubsucker & 59 & 0.125 \\
\hline 2006 & $\mathrm{BP}$ & 1 & lake chubsucker & 59 & 0.223 \\
\hline 2006 & $\mathrm{BP}$ & 1 & lake chubsucker & 60 & 0.245 \\
\hline 2006 & $\mathrm{BP}$ & 1 & lake chubsucker & 61 & 0.182 \\
\hline 2006 & $\mathrm{BP}$ & 1 & lake chubsucker & 61 & 0.325 \\
\hline 2006 & $\mathrm{BP}$ & 1 & lake chubsucker & 62 & 0.360 \\
\hline 2006 & $\mathrm{BP}$ & 1 & lake chubsucker & 62 & 0.186 \\
\hline 2006 & $\mathrm{BP}$ & 1 & lake chubsucker & 63 & 0.274 \\
\hline 2006 & $\mathrm{BP}$ & 1 & lake chubsucker & 69 & 0.269 \\
\hline 2006 & $\mathrm{BP}$ & 1 & lake chubsucker & 71 & 0.148 \\
\hline 2006 & $\mathrm{BP}$ & 1 & lake chubsucker & 76 & 0.2060 \\
\hline 2006 & $\mathrm{BP}$ & 1 & lake chubsucker & 132 & 0.101 \\
\hline 2006 & $\mathrm{BP}$ & 1 & lake chubsucker & 144 & 0.186 \\
\hline 2006 & $\mathrm{BP}$ & 1 & mud sunfish & 66 & 0.537 \\
\hline 2006 & $\mathrm{BP}$ & 1 & mud sunfish & 67 & 0.317 \\
\hline 2006 & $\mathrm{BP}$ & 1 & mud sunfish & 67 & 0.494 \\
\hline 2006 & $\mathrm{BP}$ & 1 & mud sunfish & 68 & 0.1717 \\
\hline 2006 & $\mathrm{BP}$ & 1 & mud sunfish & 70 & 0.093 \\
\hline 2006 & $\mathrm{BP}$ & 1 & mud sunfish & 71 & 0.569 \\
\hline 2006 & $\mathrm{BP}$ & 1 & mud sunfish & 71 & 0.372 \\
\hline 2006 & $\mathrm{BP}$ & 1 & mud sunfish & 75 & 0.678 \\
\hline 2006 & $\mathrm{BP}$ & 1 & mud sunfish & 75 & 0.205 \\
\hline
\end{tabular}


SRNL-STI-2012-00202

Page 51 of 64

\begin{tabular}{|c|c|c|c|c|c|}
\hline Year & Habitat & Site\# & Species & $\mathrm{TL}(\mathrm{mm})$ & Hg (ppm dry wt) \\
\hline 2006 & $\mathrm{BP}$ & 1 & mud sunfish & 81 & 0.347 \\
\hline 2006 & $\mathrm{BP}$ & 1 & mud sunfish & 91 & 0.691 \\
\hline 2006 & $\mathrm{BP}$ & 1 & mud sunfish & 109 & 1.127 \\
\hline 2006 & $\mathrm{BP}$ & 1 & mud sunfish & 113 & 0.688 \\
\hline 2006 & $\mathrm{BP}$ & 1 & mud sunfish & 137 & 0.435 \\
\hline 2006 & $\mathrm{BP}$ & 1 & mud sunfish & 156 & 0.640 \\
\hline 2006 & $\mathrm{BP}$ & 1 & pirate perch & 46 & 0.136 \\
\hline 2006 & $\mathrm{BP}$ & 1 & pirate perch & 47 & 0.248 \\
\hline 2006 & $\mathrm{BP}$ & 1 & pirate perch & 52 & 0.251 \\
\hline 2006 & $\mathrm{BP}$ & 1 & pirate perch & 68 & 0.168 \\
\hline 2006 & $\mathrm{BP}$ & 1 & pirate perch & 78 & 0.267 \\
\hline 2006 & $\mathrm{BP}$ & 1 & pirate perch & 79 & 0.214 \\
\hline 2006 & $\mathrm{BP}$ & 1 & pirate perch & 82 & 0.321 \\
\hline 2006 & $\mathrm{BP}$ & 1 & pirate perch & 88 & 0.401 \\
\hline 2006 & $\mathrm{BP}$ & 1 & pirate perch & 91 & 0.709 \\
\hline 2006 & $\mathrm{BP}$ & 1 & pirate perch & 93 & 0.434 \\
\hline 2006 & $\mathrm{BP}$ & 1 & pirate perch & 102 & 0.614 \\
\hline 2006 & $\mathrm{BP}$ & 1 & redbreast & 70 & 0.083 \\
\hline 2006 & $\mathrm{BP}$ & 1 & redfin pickerel & 109 & 0.336 \\
\hline 2006 & $\mathrm{BP}$ & 1 & redfin pickerel & 112 & 0.317 \\
\hline 2006 & $\mathrm{BP}$ & 1 & redfin pickerel & 115 & 0.309 \\
\hline 2006 & $\mathrm{BP}$ & 1 & redfin pickerel & 116 & 0.400 \\
\hline 2006 & $\mathrm{BP}$ & 1 & redfin pickerel & 118 & 0.405 \\
\hline 2006 & $\mathrm{BP}$ & 1 & redfin pickerel & 124 & 0.275 \\
\hline 2006 & $\mathrm{BP}$ & 1 & redfin pickerel & 126 & 1.055 \\
\hline 2006 & $\mathrm{BP}$ & 1 & redfin pickerel & 127 & 0.738 \\
\hline 2006 & $\mathrm{BP}$ & 1 & redfin pickerel & 131 & 1.208 \\
\hline 2006 & $\mathrm{BP}$ & 1 & redfin pickerel & 134 & 0.418 \\
\hline 2006 & $\mathrm{BP}$ & 1 & redfin pickerel & 146 & 0.814 \\
\hline 2006 & $\mathrm{BP}$ & 1 & redfin pickerel & 159 & 0.884 \\
\hline 2006 & $\mathrm{BP}$ & 1 & redfin pickerel & 161 & 0.509 \\
\hline 2006 & $\mathrm{BP}$ & 1 & redfin pickerel & 226 & 0.613 \\
\hline 2006 & $\mathrm{BP}$ & 1 & redfin pickerel & 235 & 0.414 \\
\hline 2006 & $\mathrm{BP}$ & 2 & dollar sunfish & 55 & 0.895 \\
\hline 2006 & $\mathrm{BP}$ & 2 & dollar sunfish & 56 & 0.909 \\
\hline 2006 & $\mathrm{BP}$ & 2 & dollar sunfish & 56 & 0.643 \\
\hline 2006 & $\mathrm{BP}$ & 2 & dollar sunfish & 58 & 0.700 \\
\hline 2006 & $\mathrm{BP}$ & 2 & dollar sunfish & 59 & 0.465 \\
\hline 2006 & $\mathrm{BP}$ & 2 & dollar sunfish & 60 & 1.529 \\
\hline 2006 & $\mathrm{BP}$ & 2 & dollar sunfish & 61 & 0.649 \\
\hline
\end{tabular}


SRNL-STI-2012-00202

Page 52 of 64

\begin{tabular}{|c|c|c|c|c|c|}
\hline Year & Habitat & Site\# & Species & TL (mm) & Hg (ppm dry wt) \\
\hline 2006 & $\mathrm{BP}$ & 2 & dollar sunfish & 62 & 0.416 \\
\hline 2006 & $\mathrm{BP}$ & 2 & dollar sunfish & 63 & 1.094 \\
\hline 2006 & $\mathrm{BP}$ & 2 & dollar sunfish & 63 & 0.959 \\
\hline 2006 & $\mathrm{BP}$ & 2 & dollar sunfish & 65 & 0.541 \\
\hline 2006 & $\mathrm{BP}$ & 2 & dollar sunfish & 66 & 1.070 \\
\hline 2006 & $\mathrm{BP}$ & 2 & dollar sunfish & 70 & 0.903 \\
\hline 2006 & $\mathrm{BP}$ & 2 & dollar sunfish & 71 & 1.536 \\
\hline 2006 & $\mathrm{BP}$ & 2 & dollar sunfish & 76 & 1.602 \\
\hline 2006 & $\mathrm{BP}$ & 2 & lake chubsucker & 97 & 0.910 \\
\hline 2006 & $\mathrm{BP}$ & 2 & lake chubsucker & 98 & 0.728 \\
\hline 2006 & $\mathrm{BP}$ & 2 & lake chubsucker & 100 & 0.543 \\
\hline 2006 & $\mathrm{BP}$ & 2 & lake chubsucker & 107 & 0.924 \\
\hline 2006 & $\mathrm{BP}$ & 2 & lake chubsucker & 108 & 0.827 \\
\hline 2006 & $\mathrm{BP}$ & 2 & lake chubsucker & 117 & 0.843 \\
\hline 2006 & $\mathrm{BP}$ & 2 & lake chubsucker & 118 & 1.406 \\
\hline 2006 & $\mathrm{BP}$ & 2 & lake chubsucker & 119 & 0.640 \\
\hline 2006 & $\mathrm{BP}$ & 2 & lake chubsucker & 121 & 1.067 \\
\hline 2006 & $\mathrm{BP}$ & 2 & lake chubsucker & 121 & 0.260 \\
\hline 2006 & $\mathrm{BP}$ & 2 & lake chubsucker & 121 & 0.690 \\
\hline 2006 & $\mathrm{BP}$ & 2 & lake chubsucker & 122 & 0.773 \\
\hline 2006 & $\mathrm{BP}$ & 2 & lake chubsucker & 123 & 0.633 \\
\hline 2006 & $\mathrm{BP}$ & 2 & lake chubsucker & 134 & 1.002 \\
\hline 2006 & $\mathrm{BP}$ & 2 & lake chubsucker & 159 & 1.364 \\
\hline 2006 & $\mathrm{BP}$ & 2 & lake chubsucker & 182 & 1.890 \\
\hline 2006 & $\mathrm{BP}$ & 2 & mud sunfish & 87 & 2.215 \\
\hline 2006 & $\mathrm{BP}$ & 2 & mud sunfish & 92 & 2.272 \\
\hline 2006 & $\mathrm{BP}$ & 2 & mud sunfish & 102 & 2.266 \\
\hline 2006 & $\mathrm{BP}$ & 2 & mud sunfish & 103 & 7.498 \\
\hline 2006 & $\mathrm{BP}$ & 2 & mud sunfish & 106 & 2.662 \\
\hline 2006 & $\mathrm{BP}$ & 2 & mud sunfish & 114 & 4.405 \\
\hline 2006 & $\mathrm{BP}$ & 2 & mud sunfish & 125 & 2.324 \\
\hline 2006 & $\mathrm{BP}$ & 2 & pirate perch & 62 & 0.809 \\
\hline 2006 & $\mathrm{BP}$ & 2 & pirate perch & 72 & 3.318 \\
\hline 2006 & $\mathrm{BP}$ & 2 & pirate perch & 73 & 0.645 \\
\hline 2006 & $\mathrm{BP}$ & 2 & pirate perch & 73 & 1.237 \\
\hline 2006 & $\mathrm{BP}$ & 2 & pirate perch & 73 & 1.040 \\
\hline 2006 & $\mathrm{BP}$ & 2 & pirate perch & 76 & 1.133 \\
\hline 2006 & $\mathrm{BP}$ & 2 & pirate perch & 79 & 1.863 \\
\hline 2006 & $\mathrm{BP}$ & 2 & pirate perch & 79 & 1.162 \\
\hline 2006 & $\mathrm{BP}$ & 2 & pirate perch & 86 & 1.663 \\
\hline
\end{tabular}




\begin{tabular}{|c|c|c|c|c|c|}
\hline Year & Habitat & Site\# & Species & TL (mm) & Hg (ppm dry wt) \\
\hline 2006 & $\mathrm{BP}$ & 2 & pirate perch & 87 & 0.874 \\
\hline 2006 & $\mathrm{BP}$ & 2 & pirate perch & 88 & 0.990 \\
\hline 2006 & $\mathrm{BP}$ & 2 & pirate perch & 90 & 1.191 \\
\hline 2006 & $\mathrm{BP}$ & 2 & pirate perch & 93 & 3.728 \\
\hline 2006 & $\mathrm{BP}$ & 2 & pirate perch & 96 & 2.229 \\
\hline 2006 & $\mathrm{BP}$ & 2 & redfin pickerel & 116 & 1.495 \\
\hline 2006 & $\mathrm{BP}$ & 2 & redfin pickerel & 132 & 2.888 \\
\hline 2006 & $\mathrm{BP}$ & 2 & redfin pickerel & 138 & 2.239 \\
\hline 2006 & $\mathrm{BP}$ & 2 & redfin pickerel & 140 & 5.088 \\
\hline 2006 & $\mathrm{BP}$ & 2 & redfin pickerel & 143 & 3.143 \\
\hline 2006 & $\mathrm{BP}$ & 2 & redfin pickerel & 144 & 3.783 \\
\hline 2006 & $\mathrm{BP}$ & 2 & redfin pickerel & 148 & 3.313 \\
\hline 2006 & $\mathrm{BP}$ & 2 & redfin pickerel & 157 & 3.472 \\
\hline 2006 & $\mathrm{BP}$ & 2 & redfin pickerel & 168 & 2.895 \\
\hline 2006 & $\mathrm{BP}$ & 2 & redfin pickerel & 179 & 7.335 \\
\hline 2006 & $\mathrm{BP}$ & 2 & redfin pickerel & 183 & 5.142 \\
\hline 2006 & $\mathrm{BP}$ & 2 & redfin pickerel & 204 & 5.283 \\
\hline 2006 & $\mathrm{BP}$ & 2 & warmouth & 92 & 1.215 \\
\hline 2006 & $\mathrm{BP}$ & 3 & eastern mud minnow & 51 & 0.464 \\
\hline 2006 & $\mathrm{BP}$ & 3 & eastern mud minnow & 52 & 0.700 \\
\hline 2006 & $\mathrm{BP}$ & 3 & eastern mud minnow & 62 & 0.660 \\
\hline 2006 & $\mathrm{BP}$ & 3 & eastern mud minnow & 66 & 0.377 \\
\hline 2006 & $\mathrm{BP}$ & 3 & eastern mud minnow & 69 & 1.192 \\
\hline 2006 & $\mathrm{BP}$ & 3 & eastern mud minnow & 72 & 0.472 \\
\hline 2006 & $\mathrm{BP}$ & 3 & eastern mud minnow & 76 & 0.760 \\
\hline 2006 & $\mathrm{BP}$ & 3 & eastern mud minnow & 77 & 1.062 \\
\hline 2006 & $\mathrm{BP}$ & 3 & eastern mud minnow & 80 & 1.000 \\
\hline 2006 & $\mathrm{BP}$ & 3 & eastern mud minnow & 81 & 0.708 \\
\hline 2006 & $\mathrm{BP}$ & 3 & eastern mud minnow & 82 & 0.611 \\
\hline 2006 & $\mathrm{BP}$ & 3 & eastern mud minnow & 87 & 1.200 \\
\hline 2006 & $\mathrm{BP}$ & 3 & eastern mud minnow & 88 & 1.750 \\
\hline 2006 & $\mathrm{BP}$ & 3 & eastern mud minnow & 98 & 3.220 \\
\hline 2006 & $\mathrm{BP}$ & 3 & lake chubsucker & 60 & 0.324 \\
\hline 2006 & $\mathrm{BP}$ & 3 & lake chubsucker & 68 & 0.462 \\
\hline 2006 & $\mathrm{BP}$ & 3 & lake chubsucker & 122 & 0.657 \\
\hline 2006 & $\mathrm{BP}$ & 3 & lake chubsucker & 149 & 0.279 \\
\hline 2006 & $\mathrm{BP}$ & 3 & lake chubsucker & 152 & 1.255 \\
\hline 2006 & $\mathrm{BP}$ & 3 & lake chubsucker & 156 & 1.353 \\
\hline 2006 & $\mathrm{BP}$ & 3 & lake chubsucker & 159 & 0.752 \\
\hline 2006 & $\mathrm{BP}$ & 3 & lake chubsucker & 166 & 0.763 \\
\hline
\end{tabular}




\begin{tabular}{|c|c|c|c|c|c|}
\hline Year & Habitat & Site\# & Species & TL (mm) & Hg (ppm dry wt) \\
\hline 2006 & $\mathrm{BP}$ & 3 & lake chubsucker & 174 & 1.519 \\
\hline 2006 & $\mathrm{BP}$ & 3 & lake chubsucker & 179 & 0.967 \\
\hline 2006 & $\mathrm{BP}$ & 3 & lake chubsucker & 183 & 2.182 \\
\hline 2006 & $\mathrm{BP}$ & 3 & lake chubsucker & 188 & 1.826 \\
\hline 2006 & $\mathrm{BP}$ & 3 & lake chubsucker & 191 & 1.693 \\
\hline 2006 & $\mathrm{BP}$ & 3 & lake chubsucker & 193 & 1.335 \\
\hline 2006 & $\mathrm{BP}$ & 3 & lake chubsucker & 194 & 0.572 \\
\hline 2006 & $\mathrm{BP}$ & 3 & lake chubsucker & 204 & 2.029 \\
\hline 2006 & $\mathrm{BP}$ & 3 & mud sunfish & 62 & 1.628 \\
\hline 2006 & $\mathrm{BP}$ & 3 & mud sunfish & 64 & 1.159 \\
\hline 2006 & $\mathrm{BP}$ & 3 & mud sunfish & 67 & 1.120 \\
\hline 2006 & $\mathrm{BP}$ & 3 & mud sunfish & 68 & 0.815 \\
\hline 2006 & $\mathrm{BP}$ & 3 & mud sunfish & 68 & 0.795 \\
\hline 2006 & $\mathrm{BP}$ & 3 & mud sunfish & 70 & 0.575 \\
\hline 2006 & $\mathrm{BP}$ & 3 & mud sunfish & 72 & 0.463 \\
\hline 2006 & $\mathrm{BP}$ & 3 & mud sunfish & 72 & 0.460 \\
\hline 2006 & $\mathrm{BP}$ & 3 & mud sunfish & 88 & 1.907 \\
\hline 2006 & $\mathrm{BP}$ & 3 & mud sunfish & 88 & 1.868 \\
\hline 2006 & $\mathrm{BP}$ & 3 & mud sunfish & 104 & 3.147 \\
\hline 2006 & $\mathrm{BP}$ & 3 & mud sunfish & 107 & 2.841 \\
\hline 2006 & $\mathrm{BP}$ & 3 & mud sunfish & 110 & 2.061 \\
\hline 2006 & $\mathrm{BP}$ & 3 & mud sunfish & 110 & 2.885 \\
\hline 2006 & $\mathrm{BP}$ & 3 & mud sunfish & 115 & 2.341 \\
\hline 2006 & $\mathrm{BP}$ & 3 & pirate perch & 50 & 0.261 \\
\hline 2006 & $\mathrm{BP}$ & 3 & pirate perch & 55 & 0.910 \\
\hline 2006 & $\mathrm{BP}$ & 3 & pirate perch & 55 & 0.909 \\
\hline 2006 & $\mathrm{BP}$ & 3 & pirate perch & 61 & 0.474 \\
\hline 2006 & $\mathrm{BP}$ & 3 & pirate perch & 68 & 0.705 \\
\hline 2006 & $\mathrm{BP}$ & 3 & pirate perch & 68 & 0.598 \\
\hline 2006 & $\mathrm{BP}$ & 3 & pirate perch & 69 & 1.310 \\
\hline 2006 & $\mathrm{BP}$ & 3 & pirate perch & 70 & 0.811 \\
\hline 2006 & $\mathrm{BP}$ & 3 & pirate perch & 71 & 0.633 \\
\hline 2006 & $\mathrm{BP}$ & 3 & pirate perch & 72 & 0.719 \\
\hline 2006 & $\mathrm{BP}$ & 3 & pirate perch & 73 & 1.152 \\
\hline 2006 & $\mathrm{BP}$ & 3 & pirate perch & 74 & 0.860 \\
\hline 2006 & $\mathrm{BP}$ & 3 & pirate perch & 74 & 0.380 \\
\hline 2006 & $\mathrm{BP}$ & 3 & pirate perch & 78 & 0.647 \\
\hline 2006 & $\mathrm{BP}$ & 3 & pirate perch & 91 & 1.141 \\
\hline 2006 & $\mathrm{BP}$ & 3 & redfin pickerel & 101 & 0.680 \\
\hline 2006 & $\mathrm{BP}$ & 3 & redfin pickerel & 104 & 0.754 \\
\hline
\end{tabular}




\begin{tabular}{|c|c|c|c|c|c|}
\hline Year & Habitat & Site\# & Species & TL (mm) & Hg (ppm dry wt) \\
\hline 2006 & $\mathrm{BP}$ & 3 & redfin pickerel & 104 & 1.473 \\
\hline 2006 & $\mathrm{BP}$ & 3 & redfin pickerel & 104 & 1.912 \\
\hline 2006 & $\mathrm{BP}$ & 3 & redfin pickerel & 105 & 2.369 \\
\hline 2006 & $\mathrm{BP}$ & 3 & redfin pickerel & 107 & 3.123 \\
\hline 2006 & $\mathrm{BP}$ & 3 & redfin pickerel & 162 & 3.329 \\
\hline 2006 & $\mathrm{BP}$ & 3 & redfin pickerel & 181 & 4.015 \\
\hline 2006 & $\mathrm{BP}$ & 3 & redfin pickerel & 265 & 7.218 \\
\hline 2006 & $\mathrm{BP}$ & 4 & dollar sunfish & 51 & 0.854 \\
\hline 2006 & $\mathrm{BP}$ & 4 & dollar sunfish & 56 & 0.644 \\
\hline 2006 & $\mathrm{BP}$ & 4 & dollar sunfish & 56 & 0.771 \\
\hline 2006 & $\mathrm{BP}$ & 4 & dollar sunfish & 57 & 0.871 \\
\hline 2006 & $\mathrm{BP}$ & 4 & dollar sunfish & 57 & 0.709 \\
\hline 2006 & $\mathrm{BP}$ & 4 & dollar sunfish & 60 & 0.574 \\
\hline 2006 & $\mathrm{BP}$ & 4 & dollar sunfish & 61 & 0.303 \\
\hline 2006 & $\mathrm{BP}$ & 4 & dollar sunfish & 61 & 0.742 \\
\hline 2006 & $\mathrm{BP}$ & 4 & dollar sunfish & 62 & 0.612 \\
\hline 2006 & $\mathrm{BP}$ & 4 & dollar sunfish & 79 & 0.570 \\
\hline 2006 & BP & 4 & dollar sunfish & 85 & 0.887 \\
\hline 2006 & $\mathrm{BP}$ & 4 & dollar sunfish & 88 & 0.708 \\
\hline 2006 & $\mathrm{BP}$ & 4 & dollar sunfish & 88 & 0.916 \\
\hline 2006 & $\mathrm{BP}$ & 4 & dollar sunfish & 103 & 0.676 \\
\hline 2006 & $\mathrm{BP}$ & 4 & lake chubsucker & 51 & 0.122 \\
\hline 2006 & $\mathrm{BP}$ & 4 & lake chubsucker & 51 & 0.183 \\
\hline 2006 & BP & 4 & lake chubsucker & 54 & 0.692 \\
\hline 2006 & $\mathrm{BP}$ & 4 & lake chubsucker & 55 & 0.242 \\
\hline 2006 & $\mathrm{BP}$ & 4 & lake chubsucker & 60 & 0.269 \\
\hline 2006 & $\mathrm{BP}$ & 4 & lake chubsucker & 70 & 0.639 \\
\hline 2006 & $\mathrm{BP}$ & 4 & lake chubsucker & 94 & 0.449 \\
\hline 2006 & $\mathrm{BP}$ & 4 & lake chubsucker & 98 & 0.773 \\
\hline 2006 & $\mathrm{BP}$ & 4 & lake chubsucker & 102 & 0.556 \\
\hline 2006 & $\mathrm{BP}$ & 4 & lake chubsucker & 110 & 0.437 \\
\hline 2006 & $\mathrm{BP}$ & 4 & lake chubsucker & 110 & 0.593 \\
\hline 2006 & $\mathrm{BP}$ & 4 & lake chubsucker & 131 & 0.943 \\
\hline 2006 & $\mathrm{BP}$ & 4 & lake chubsucker & 167 & 1.149 \\
\hline 2006 & $\mathrm{BP}$ & 4 & lake chubsucker & 218 & 0.800 \\
\hline 2006 & $\mathrm{BP}$ & 4 & lake chubsucker & 219 & 0.694 \\
\hline 2006 & $\mathrm{BP}$ & 4 & mud sunfish & 58 & 0.399 \\
\hline 2006 & $\mathrm{BP}$ & 4 & mud sunfish & 64 & 0.916 \\
\hline 2006 & $\mathrm{BP}$ & 4 & mud sunfish & 69 & 0.579 \\
\hline 2006 & $\mathrm{BP}$ & 4 & mud sunfish & 74 & 0.654 \\
\hline
\end{tabular}




\begin{tabular}{|c|c|c|c|c|c|}
\hline Year & Habitat & Site\# & Species & TL (mm) & Hg (ppm dry wt) \\
\hline 2006 & $\mathrm{BP}$ & 4 & mud sunfish & 78 & 0.995 \\
\hline 2006 & $\mathrm{BP}$ & 4 & mud sunfish & 81 & 0.803 \\
\hline 2006 & $\mathrm{BP}$ & 4 & mud sunfish & 81 & 0.718 \\
\hline 2006 & $\mathrm{BP}$ & 4 & mud sunfish & 90 & 0.828 \\
\hline 2006 & $\mathrm{BP}$ & 4 & mud sunfish & 93 & 0.955 \\
\hline 2006 & $\mathrm{BP}$ & 4 & mud sunfish & 100 & 0.664 \\
\hline 2006 & $\mathrm{BP}$ & 4 & mud sunfish & 113 & 2.940 \\
\hline 2006 & $\mathrm{BP}$ & 4 & mud sunfish & 113 & 1.512 \\
\hline 2006 & $\mathrm{BP}$ & 4 & mud sunfish & 115 & 0.554 \\
\hline 2006 & $\mathrm{BP}$ & 4 & mud sunfish & 119 & 1.048 \\
\hline 2006 & $\mathrm{BP}$ & 4 & mud sunfish & 121 & 1.460 \\
\hline 2006 & $\mathrm{BP}$ & 4 & redfin pickerel & 76 & 0.537 \\
\hline 2006 & $\mathrm{BP}$ & 4 & redfin pickerel & 79 & 0.710 \\
\hline 2006 & $\mathrm{BP}$ & 4 & redfin pickerel & 98 & 0.625 \\
\hline 2006 & $\mathrm{BP}$ & 4 & redfin pickerel & 154 & 1.847 \\
\hline 2006 & $\mathrm{BP}$ & 4 & redfin pickerel & 161 & 1.317 \\
\hline 2006 & $\mathrm{BP}$ & 4 & redfin pickerel & 161 & 1.186 \\
\hline 2006 & $\mathrm{BP}$ & 4 & redfin pickerel & 164 & 1.966 \\
\hline 2006 & $\mathrm{BP}$ & 4 & redfin pickerel & 168 & 1.457 \\
\hline 2006 & $\mathrm{BP}$ & 4 & redfin pickerel & 169 & 1.878 \\
\hline 2006 & $\mathrm{BP}$ & 4 & redfin pickerel & 170 & 1.787 \\
\hline 2006 & $\mathrm{BP}$ & 4 & redfin pickerel & 185 & 1.344 \\
\hline 2006 & $\mathrm{BP}$ & 4 & redfin pickerel & 216 & 2.180 \\
\hline 2006 & $\mathrm{BP}$ & 4 & spotted sunfish & 60 & 0.750 \\
\hline 2006 & $\mathrm{BP}$ & 4 & spotted sunfish & 64 & 0.417 \\
\hline 2006 & $\mathrm{BP}$ & 4 & spotted sunfish & 67 & 0.881 \\
\hline 2006 & $\mathrm{BP}$ & 4 & spotted sunfish & 73 & 0.817 \\
\hline 2006 & $\mathrm{BP}$ & 4 & spotted sunfish & 82 & 0.408 \\
\hline 2006 & $\mathrm{BP}$ & 4 & spotted sunfish & 83 & 0.798 \\
\hline 2006 & $\mathrm{BP}$ & 4 & spotted sunfish & 94 & 0.327 \\
\hline 2006 & $\mathrm{BP}$ & 4 & spotted sunfish & 97 & 0.348 \\
\hline 2006 & $\mathrm{BP}$ & 4 & spotted sunfish & 104 & 0.374 \\
\hline 2006 & $\mathrm{BP}$ & 4 & spotted sunfish & 106 & 0.513 \\
\hline 2006 & $\mathrm{BP}$ & 4 & spotted sunfish & 109 & 0.777 \\
\hline 2006 & $\mathrm{BP}$ & 4 & spotted sunfish & 112 & 0.566 \\
\hline 2006 & $\mathrm{BP}$ & 4 & spotted sunfish & 112 & 0.438 \\
\hline 2006 & $\mathrm{BP}$ & 4 & spotted sunfish & 143 & 1.232 \\
\hline 2006 & $\mathrm{BP}$ & 4 & spotted sunfish & 157 & 1.365 \\
\hline 2006 & $\mathrm{BP}$ & 4 & warmouth & 70 & 0.308 \\
\hline 2006 & $\mathrm{BP}$ & 4 & warmouth & 78 & 0.357 \\
\hline
\end{tabular}


SRNL-STI-2012-00202

Page 57 of 64

\begin{tabular}{|c|c|c|c|c|c|}
\hline Year & Habitat & Site\# & Species & TL (mm) & Hg (ppm dry wt) \\
\hline 2006 & SR & 1 & lake chubsucker & 52 & 0.126 \\
\hline 2006 & SR & 1 & lake chubsucker & 56 & 0.246 \\
\hline 2006 & $\mathrm{SR}$ & 1 & lake chubsucker & 71 & 0.375 \\
\hline 2006 & $\mathrm{SR}$ & 1 & lake chubsucker & 73 & 0.249 \\
\hline 2006 & $\mathrm{SR}$ & 1 & lake chubsucker & 74 & 0.221 \\
\hline 2006 & $\mathrm{SR}$ & 1 & lake chubsucker & 77 & 0.150 \\
\hline 2006 & SR & 1 & lake chubsucker & 81 & 0.296 \\
\hline 2006 & SR & 1 & lake chubsucker & 92 & 0.150 \\
\hline 2006 & SR & 1 & lake chubsucker & 97 & 0.170 \\
\hline 2006 & SR & 1 & lake chubsucker & 106 & 0.118 \\
\hline 2006 & SR & 1 & lake chubsucker & 109 & 0.121 \\
\hline 2006 & SR & 1 & mud sunfish & 61 & 0.322 \\
\hline 2006 & $\mathrm{SR}$ & 1 & mud sunfish & 67 & 0.003 \\
\hline 2006 & SR & 1 & mud sunfish & 67 & 0.143 \\
\hline 2006 & SR & 1 & mud sunfish & 70 & 0.216 \\
\hline 2006 & SR & 1 & mud sunfish & 70 & 0.291 \\
\hline 2006 & SR & 1 & mud sunfish & 73 & 0.363 \\
\hline 2006 & SR & 1 & mud sunfish & 73 & 0.160 \\
\hline 2006 & $\mathrm{SR}$ & 1 & mud sunfish & 76 & 0.266 \\
\hline 2006 & SR & 1 & mud sunfish & 76 & 0.185 \\
\hline 2006 & SR & 1 & mud sunfish & 77 & 0.152 \\
\hline 2006 & $\mathrm{SR}$ & 1 & mud sunfish & 78 & 0.273 \\
\hline 2006 & SR & 1 & mud sunfish & 81 & 0.590 \\
\hline 2006 & $\mathrm{SR}$ & 1 & mud sunfish & 84 & 0.234 \\
\hline 2006 & $\mathrm{SR}$ & 1 & mud sunfish & 87 & 0.343 \\
\hline 2006 & $\mathrm{SR}$ & 1 & pirate perch & 62 & 0.234 \\
\hline 2006 & $\mathrm{SR}$ & 1 & pirate perch & 64 & 0.031 \\
\hline 2006 & SR & 1 & pirate perch & 64 & 0.074 \\
\hline 2006 & SR & 1 & pirate perch & 66 & 0.034 \\
\hline 2006 & SR & 1 & pirate perch & 67 & 0.124 \\
\hline 2006 & SR & 1 & pirate perch & 68 & 0.162 \\
\hline 2006 & $\mathrm{SR}$ & 1 & pirate perch & 68 & 0.267 \\
\hline 2006 & SR & 1 & pirate perch & 69 & 0.043 \\
\hline 2006 & $\mathrm{SR}$ & 1 & pirate perch & 70 & 0.122 \\
\hline 2006 & SR & 1 & pirate perch & 70 & 0.113 \\
\hline 2006 & SR & 1 & pirate perch & 78 & 0.129 \\
\hline 2006 & $\mathrm{SR}$ & 1 & pirate perch & 78 & 0.163 \\
\hline 2006 & $\mathrm{SR}$ & 1 & pirate perch & 80 & 0.132 \\
\hline 2006 & $\mathrm{SR}$ & 1 & pirate perch & 81 & 0.313 \\
\hline 2006 & SR & 1 & pirate perch & 85 & 0.154 \\
\hline
\end{tabular}


SRNL-STI-2012-00202

Page 58 of 64

\begin{tabular}{|c|c|c|c|c|c|}
\hline Year & Habitat & Site\# & Species & TL (mm) & Hg (ppm dry wt) \\
\hline 2006 & SR & 1 & redfin pickerel & 102 & 0.194 \\
\hline 2006 & SR & 1 & redfin pickerel & 104 & 0.119 \\
\hline 2006 & $\mathrm{SR}$ & 1 & redfin pickerel & 104 & 0.318 \\
\hline 2006 & $\mathrm{SR}$ & 1 & redfin pickerel & 106 & 0.092 \\
\hline 2006 & SR & 1 & redfin pickerel & 111 & 0.173 \\
\hline 2006 & SR & 1 & redfin pickerel & 111 & 0.114 \\
\hline 2006 & SR & 1 & redfin pickerel & 112 & 0.842 \\
\hline 2006 & SR & 1 & redfin pickerel & 113 & 0.183 \\
\hline 2006 & SR & 1 & redfin pickerel & 122 & 0.345 \\
\hline 2006 & SR & 1 & redfin pickerel & 124 & 0.809 \\
\hline 2006 & SR & 1 & redfin pickerel & 126 & 0.106 \\
\hline 2006 & SR & 1 & redfin pickerel & 127 & 0.743 \\
\hline 2006 & SR & 1 & redfin pickerel & 137 & 0.804 \\
\hline 2006 & SR & 1 & redfin pickerel & 143 & 0.533 \\
\hline 2006 & SR & 1 & redfin pickerel & 194 & 0.936 \\
\hline 2006 & SR & 2 & dollar sunfish & 62 & 0.173 \\
\hline 2006 & SR & 2 & dollar sunfish & 62 & 0.901 \\
\hline 2006 & SR & 2 & dollar sunfish & 62 & 0.913 \\
\hline 2006 & $\mathrm{SR}$ & 2 & dollar sunfish & 63 & 0.677 \\
\hline 2006 & $\mathrm{SR}$ & 2 & dollar sunfish & 63 & 0.738 \\
\hline 2006 & SR & 2 & dollar sunfish & 64 & 0.539 \\
\hline 2006 & SR & 2 & dollar sunfish & 64 & 0.886 \\
\hline 2006 & SR & 2 & dollar sunfish & 65 & 0.869 \\
\hline 2006 & SR & 2 & dollar sunfish & 65 & 0.263 \\
\hline 2006 & SR & 2 & dollar sunfish & 68 & 0.987 \\
\hline 2006 & $\mathrm{SR}$ & 2 & dollar sunfish & 70 & 0.631 \\
\hline 2006 & SR & 2 & dollar sunfish & 72 & 0.653 \\
\hline 2006 & $\mathrm{SR}$ & 2 & dollar sunfish & 75 & 0.986 \\
\hline 2006 & SR & 2 & dollar sunfish & 75 & 0.590 \\
\hline 2006 & SR & 2 & dollar sunfish & 76 & 0.685 \\
\hline 2006 & SR & 2 & lake chubsucker & 105 & 0.388 \\
\hline 2006 & SR & 2 & lake chubsucker & 106 & 0.353 \\
\hline 2006 & $\mathrm{SR}$ & 2 & lake chubsucker & 107 & 0.598 \\
\hline 2006 & $\mathrm{SR}$ & 2 & lake chubsucker & 116 & 0.250 \\
\hline 2006 & SR & 2 & lake chubsucker & 120 & 0.389 \\
\hline 2006 & SR & 2 & lake chubsucker & 122 & 0.392 \\
\hline 2006 & SR & 2 & lake chubsucker & 125 & 0.300 \\
\hline 2006 & $\mathrm{SR}$ & 2 & lake chubsucker & 126 & 0.397 \\
\hline 2006 & SR & 2 & lake chubsucker & 128 & 0.167 \\
\hline 2006 & $\mathrm{SR}$ & 2 & lake chubsucker & 132 & 0.440 \\
\hline
\end{tabular}


SRNL-STI-2012-00202

Page 59 of 64

\begin{tabular}{|c|c|c|c|c|c|}
\hline Year & Habitat & Site\# & Species & TL (mm) & Hg (ppm dry wt) \\
\hline 2006 & SR & 2 & lake chubsucker & 149 & 0.350 \\
\hline 2006 & SR & 2 & lake chubsucker & 152 & 0.411 \\
\hline 2006 & SR & 2 & mud sunfish & 61 & 0.752 \\
\hline 2006 & SR & 2 & mud sunfish & 64 & 0.638 \\
\hline 2006 & SR & 2 & mud sunfish & 76 & 0.557 \\
\hline 2006 & SR & 2 & mud sunfish & 77 & 0.633 \\
\hline 2006 & SR & 2 & mud sunfish & 82 & 1.112 \\
\hline 2006 & SR & 2 & mud sunfish & 90 & 1.421 \\
\hline 2006 & SR & 2 & mud sunfish & 97 & 1.765 \\
\hline 2006 & SR & 2 & mud sunfish & 130 & 2.411 \\
\hline 2006 & SR & 2 & mud sunfish & 811 & 0.619 \\
\hline 2006 & SR & 2 & pirate perch & 50 & 0.220 \\
\hline 2006 & SR & 2 & pirate perch & 51 & 0.231 \\
\hline 2006 & SR & 2 & pirate perch & 56 & 0.301 \\
\hline 2006 & SR & 2 & pirate perch & 58 & 0.353 \\
\hline 2006 & SR & 2 & pirate perch & 58 & 0.165 \\
\hline 2006 & SR & 2 & pirate perch & 64 & 0.181 \\
\hline 2006 & SR & 2 & pirate perch & 65 & 0.776 \\
\hline 2006 & SR & 2 & pirate perch & 70 & 0.940 \\
\hline 2006 & SR & 2 & pirate perch & 72 & 0.677 \\
\hline 2006 & SR & 2 & pirate perch & 73 & 0.600 \\
\hline 2006 & SR & 2 & pirate perch & 80 & 0.611 \\
\hline 2006 & SR & 2 & pirate perch & 83 & 0.328 \\
\hline 2006 & SR & 2 & pirate perch & 86 & 0.734 \\
\hline 2006 & SR & 2 & pirate perch & 89 & 0.814 \\
\hline 2006 & SR & 2 & pirate perch & 100 & 0.660 \\
\hline 2006 & SR & 2 & redfin pickerel & 88 & 0.814 \\
\hline 2006 & SR & 2 & redfin pickerel & 97 & 0.710 \\
\hline 2006 & SR & 2 & redfin pickerel & 101 & 0.618 \\
\hline 2006 & SR & 2 & redfin pickerel & 107 & 0.754 \\
\hline 2006 & SR & 2 & redfin pickerel & 107 & 0.704 \\
\hline 2006 & SR & 2 & redfin pickerel & 108 & 0.642 \\
\hline 2006 & SR & 2 & redfin pickerel & 110 & 0.572 \\
\hline 2006 & SR & 2 & redfin pickerel & 111 & 0.766 \\
\hline 2006 & SR & 2 & redfin pickerel & 121 & 0.705 \\
\hline 2006 & SR & 2 & redfin pickerel & 136 & 0.789 \\
\hline 2006 & SR & 2 & redfin pickerel & 142 & 1.235 \\
\hline 2006 & SR & 2 & redfin pickerel & 150 & 1.973 \\
\hline 2006 & SR & 2 & redfin pickerel & 157 & 1.178 \\
\hline 2006 & SR & 2 & redfin pickerel & 172 & 1.885 \\
\hline
\end{tabular}


SRNL-STI-2012-00202

Page 60 of 64

\begin{tabular}{|c|c|c|c|c|c|}
\hline Year & Habitat & Site\# & Species & TL (mm) & Hg (ppm dry wt) \\
\hline 2006 & SR & 2 & warmouth & 95 & 1.282 \\
\hline 2006 & $\overline{S R}$ & 3 & lake chubsucker & 61 & 1.412 \\
\hline 2006 & SR & 3 & lake chubsucker & 62 & 1.283 \\
\hline 2006 & SR & 3 & lake chubsucker & 63 & 1.374 \\
\hline 2006 & SR & 3 & lake chubsucker & 65 & 0.781 \\
\hline 2006 & SR & 3 & lake chubsucker & 67 & 1.063 \\
\hline 2006 & SR & 3 & lake chubsucker & 70 & 0.852 \\
\hline 2006 & SR & 3 & lake chubsucker & 73 & 0.536 \\
\hline 2006 & SR & 3 & lake chubsucker & 81 & 0.590 \\
\hline 2006 & SR & 3 & lake chubsucker & 85 & 0.698 \\
\hline 2006 & SR & 3 & lake chubsucker & 115 & 0.441 \\
\hline 2006 & SR & 3 & lake chubsucker & 118 & 0.565 \\
\hline 2006 & SR & 3 & lake chubsucker & 134 & 0.583 \\
\hline 2006 & SR & 3 & lake chubsucker & 165 & 0.700 \\
\hline 2006 & SR & 3 & lake chubsucker & 176 & 0.741 \\
\hline 2006 & SR & 3 & lake chubsucker & 179 & 0.835 \\
\hline 2006 & SR & 3 & mud sunfish & 62 & 1.026 \\
\hline 2006 & SR & 3 & mud sunfish & 62 & 1.035 \\
\hline 2006 & SR & 3 & mud sunfish & 63 & 1.710 \\
\hline 2006 & SR & 3 & mud sunfish & 63 & 1.383 \\
\hline 2006 & SR & 3 & mud sunfish & 67 & 1.145 \\
\hline 2006 & SR & 3 & mud sunfish & 74 & 0.964 \\
\hline 2006 & SR & 3 & mud sunfish & 81 & 1.086 \\
\hline 2006 & SR & 3 & mud sunfish & 84 & 1.088 \\
\hline 2006 & SR & 3 & mud sunfish & 88 & 0.808 \\
\hline 2006 & SR & 3 & mud sunfish & 88 & 1.032 \\
\hline 2006 & SR & 3 & mud sunfish & 89 & 1.383 \\
\hline 2006 & SR & 3 & mud sunfish & 91 & 1.034 \\
\hline 2006 & SR & 3 & mud sunfish & 92 & 1.533 \\
\hline 2006 & SR & 3 & mud sunfish & 94 & 0.770 \\
\hline 2006 & SR & 3 & mud sunfish & 99 & 0.906 \\
\hline 2006 & SR & 3 & pirate perch & 63 & 0.820 \\
\hline 2006 & SR & 3 & pirate perch & 65 & 1.047 \\
\hline 2006 & $\mathrm{SR}$ & 3 & pirate perch & 65 & 0.679 \\
\hline 2006 & SR & 3 & pirate perch & 65 & 0.533 \\
\hline 2006 & SR & 3 & pirate perch & 68 & 0.801 \\
\hline 2006 & SR & 3 & pirate perch & 68 & 0.554 \\
\hline 2006 & SR & 3 & pirate perch & 69 & 0.859 \\
\hline 2006 & SR & 3 & pirate perch & 69 & 0.647 \\
\hline 2006 & SR & 3 & pirate perch & 71 & 0.610 \\
\hline
\end{tabular}


SRNL-STI-2012-00202

Page 61 of 64

\begin{tabular}{|c|c|c|c|c|c|}
\hline Year & Habitat & Site\# & Species & $\mathrm{TL}(\mathrm{mm})$ & Hg (ppm dry wt) \\
\hline 2006 & SR & 3 & pirate perch & 73 & 0.581 \\
\hline 2006 & SR & 3 & pirate perch & 76 & 0.571 \\
\hline 2006 & SR & 3 & pirate perch & 77 & 0.672 \\
\hline 2006 & SR & 3 & pirate perch & 78 & 0.687 \\
\hline 2006 & SR & 3 & pirate perch & 84 & 0.851 \\
\hline 2006 & SR & 3 & pirate perch & 87 & 1.260 \\
\hline 2006 & SR & 3 & redfin pickerel & 79 & 1.533 \\
\hline 2006 & SR & 3 & redfin pickerel & 87 & 1.214 \\
\hline 2006 & $\mathrm{SR}$ & 3 & redfin pickerel & 92 & 1.796 \\
\hline 2006 & $\mathrm{SR}$ & 3 & redfin pickerel & 105 & 0.981 \\
\hline 2006 & SR & 3 & redfin pickerel & 117 & 1.176 \\
\hline 2006 & SR & 3 & redfin pickerel & 130 & 1.532 \\
\hline 2006 & SR & 3 & redfin pickerel & 134 & 1.254 \\
\hline 2006 & SR & 3 & redfin pickerel & 140 & 1.549 \\
\hline 2006 & SR & 3 & redfin pickerel & 153 & 1.394 \\
\hline 2006 & SR & 3 & redfin pickerel & 163 & 1.679 \\
\hline 2006 & SR & 3 & redfin pickerel & 176 & 1.090 \\
\hline 2006 & SR & 3 & redfin pickerel & 181 & 1.639 \\
\hline 2006 & SR & 4 & lake chubsucker & 58 & 1.064 \\
\hline 2006 & SR & 4 & lake chubsucker & 92 & 0.369 \\
\hline 2006 & SR & 4 & lake chubsucker & 96 & 0.517 \\
\hline 2006 & SR & 4 & lake chubsucker & 108 & 0.868 \\
\hline 2006 & SR & 4 & lake chubsucker & 116 & 0.593 \\
\hline 2006 & SR & 4 & lake chubsucker & 131 & 0.877 \\
\hline 2006 & SR & 4 & lake chubsucker & 140 & 0.742 \\
\hline 2006 & $\mathrm{SR}$ & 4 & mud sunfish & 64 & 1.322 \\
\hline 2006 & SR & 4 & mud sunfish & 65 & 0.999 \\
\hline 2006 & SR & 4 & mud sunfish & 65 & 1.582 \\
\hline 2006 & SR & 4 & mud sunfish & 66 & 0.869 \\
\hline 2006 & SR & 4 & mud sunfish & 67 & 1.337 \\
\hline 2006 & SR & 4 & mud sunfish & 67 & 1.170 \\
\hline 2006 & SR & 4 & mud sunfish & 67 & 1.143 \\
\hline 2006 & SR & 4 & mud sunfish & 69 & 1.613 \\
\hline 2006 & SR & 4 & mud sunfish & 69 & 1.112 \\
\hline 2006 & SR & 4 & mud sunfish & 69 & 1.261 \\
\hline 2006 & SR & 4 & mud sunfish & 70 & 0.916 \\
\hline 2006 & SR & 4 & mud sunfish & 70 & 0.939 \\
\hline 2006 & SR & 4 & mud sunfish & 74 & 1.328 \\
\hline 2006 & SR & 4 & mud sunfish & 86 & 0.837 \\
\hline 2006 & SR & 4 & mud sunfish & 98 & 0.805 \\
\hline
\end{tabular}


SRNL-STI-2012-00202

Page 62 of 64

\begin{tabular}{|c|c|c|c|c|c|}
\hline Year & Habitat & Site\# & Species & TL (mm) & Hg (ppm dry wt) \\
\hline 2006 & SR & 4 & pirate perch & 63 & 1.286 \\
\hline 2006 & SR & 4 & pirate perch & 71 & 1.008 \\
\hline 2006 & $\mathrm{SR}$ & 4 & pirate perch & 71 & 0.784 \\
\hline 2006 & $\mathrm{SR}$ & 4 & pirate perch & 71 & 0.742 \\
\hline 2006 & SR & 4 & pirate perch & 71 & 1.055 \\
\hline 2006 & SR & 4 & pirate perch & 72 & 1.090 \\
\hline 2006 & SR & 4 & pirate perch & 72 & 0.866 \\
\hline 2006 & SR & 4 & pirate perch & 73 & 1.962 \\
\hline 2006 & SR & 4 & pirate perch & 73 & 0.816 \\
\hline 2006 & SR & 4 & pirate perch & 74 & 1.354 \\
\hline 2006 & SR & 4 & pirate perch & 74 & 0.771 \\
\hline 2006 & SR & 4 & pirate perch & 77 & 0.964 \\
\hline 2006 & SR & 4 & pirate perch & 81 & 1.254 \\
\hline 2006 & SR & 4 & pirate perch & 81 & 0.741 \\
\hline 2006 & SR & 4 & pirate perch & 83 & 1.087 \\
\hline 2006 & SR & 4 & redfin pickerel & 86 & 1.007 \\
\hline 2006 & SR & 4 & redfin pickerel & 95 & 1.209 \\
\hline 2006 & SR & 4 & redfin pickerel & 101 & 1.169 \\
\hline 2006 & $\mathrm{SR}$ & 4 & redfin pickerel & 103 & 0.866 \\
\hline 2006 & SR & 4 & redfin pickerel & 111 & 0.938 \\
\hline 2006 & SR & 4 & redfin pickerel & 113 & 1.320 \\
\hline 2006 & SR & 4 & redfin pickerel & 115 & 0.940 \\
\hline 2006 & SR & 4 & redfin pickerel & 116 & 0.257 \\
\hline 2006 & SR & 4 & redfin pickerel & 118 & 0.962 \\
\hline 2006 & $\mathrm{SR}$ & 4 & redfin pickerel & 120 & 0.164 \\
\hline 2006 & $\mathrm{SR}$ & 4 & redfin pickerel & 132 & 0.810 \\
\hline 2006 & SR & 4 & redfin pickerel & 133 & 1.360 \\
\hline 2006 & SR & 4 & redfin pickerel & 146 & 1.575 \\
\hline 2006 & SR & 5 & dollar sunfish & 52 & 0.637 \\
\hline 2006 & SR & 5 & dollar sunfish & 53 & 1.003 \\
\hline 2006 & SR & 5 & dollar sunfish & 53 & 0.637 \\
\hline 2006 & SR & 5 & dollar sunfish & 56 & 0.557 \\
\hline 2006 & SR & 5 & dollar sunfish & 57 & 0.623 \\
\hline 2006 & SR & 5 & dollar sunfish & 59 & 0.596 \\
\hline 2006 & SR & 5 & dollar sunfish & 59 & 0.453 \\
\hline 2006 & $\mathrm{SR}$ & 5 & dollar sunfish & 61 & 0.395 \\
\hline 2006 & $\mathrm{SR}$ & 5 & dollar sunfish & 61 & 1.289 \\
\hline 2006 & SR & 5 & dollar sunfish & 66 & 0.889 \\
\hline 2006 & SR & 5 & dollar sunfish & 70 & 0.882 \\
\hline 2006 & SR & 5 & dollar sunfish & 71 & 1.009 \\
\hline
\end{tabular}


SRNL-STI-2012-00202

Page 63 of 64

\begin{tabular}{|c|c|c|c|c|c|}
\hline Year & Habitat & Site\# & Species & TL (mm) & Hg (ppm dry wt) \\
\hline 2006 & SR & 5 & dollar sunfish & 82 & 0.810 \\
\hline 2006 & SR & 5 & dollar sunfish & 87 & 0.940 \\
\hline 2006 & SR & 5 & dollar sunfish & 91 & 0.777 \\
\hline 2006 & SR & 5 & lake chubsucker & 128 & 0.517 \\
\hline 2006 & SR & 5 & lake chubsucker & 130 & 0.478 \\
\hline 2006 & SR & 5 & lake chubsucker & 137 & 0.704 \\
\hline 2006 & SR & 5 & lake chubsucker & 157 & 1.119 \\
\hline 2006 & SR & 5 & lake chubsucker & 165 & 1.530 \\
\hline 2006 & SR & 5 & lake chubsucker & 185 & 1.818 \\
\hline 2006 & SR & 5 & mud sunfish & 55 & 1.039 \\
\hline 2006 & SR & 5 & mud sunfish & 86 & 1.015 \\
\hline 2006 & SR & 5 & mud sunfish & 94 & 0.954 \\
\hline 2006 & $\mathrm{SR}$ & 5 & mud sunfish & 101 & 1.321 \\
\hline 2006 & SR & 5 & mud sunfish & 102 & 1.311 \\
\hline 2006 & SR & 5 & mud sunfish & 106 & 1.513 \\
\hline 2006 & SR & 5 & mud sunfish & 106 & 1.236 \\
\hline 2006 & SR & 5 & mud sunfish & 108 & 1.591 \\
\hline 2006 & SR & 5 & mud sunfish & 110 & 1.449 \\
\hline 2006 & SR & 5 & mud sunfish & 116 & 5.350 \\
\hline 2006 & SR & 5 & mud sunfish & 119 & 2.248 \\
\hline 2006 & SR & 5 & mud sunfish & 125 & 2.353 \\
\hline 2006 & SR & 5 & pirate perch & 53 & 0.459 \\
\hline 2006 & SR & 5 & pirate perch & 58 & 0.470 \\
\hline 2006 & SR & 5 & pirate perch & 59 & 0.432 \\
\hline 2006 & SR & 5 & pirate perch & 61 & 0.456 \\
\hline 2006 & SR & 5 & pirate perch & 61 & 0.394 \\
\hline 2006 & SR & 5 & pirate perch & 65 & 0.611 \\
\hline 2006 & SR & 5 & pirate perch & 65 & 0.426 \\
\hline 2006 & SR & 5 & pirate perch & 66 & 0.406 \\
\hline 2006 & SR & 5 & pirate perch & 70 & 0.562 \\
\hline 2006 & SR & 5 & pirate perch & 70 & 0.702 \\
\hline 2006 & SR & 5 & pirate perch & 77 & 1.106 \\
\hline 2006 & SR & 5 & pirate perch & 82 & 0.772 \\
\hline 2006 & $\mathrm{SR}$ & 5 & pirate perch & 82 & 1.204 \\
\hline 2006 & SR & 5 & pirate perch & 84 & 0.637 \\
\hline 2006 & SR & 5 & pirate perch & 84 & 0.900 \\
\hline 2006 & SR & 5 & redfin pickerel & 64 & 0.877 \\
\hline 2006 & SR & 5 & redfin pickerel & 120 & 1.083 \\
\hline 2006 & SR & 5 & redfin pickerel & 138 & 1.344 \\
\hline 2006 & SR & 5 & redfin pickerel & 141 & 1.478 \\
\hline
\end{tabular}


SRNL-STI-2012-00202

Page 64 of 64

\begin{tabular}{|c|c|c|c|c|c|}
\hline Year & Habitat & Site\# & Species & TL (mm) & Hg (ppm dry wt) \\
\hline 2006 & SR & 5 & redfin pickerel & 150 & 1.182 \\
\hline 2006 & SR & 5 & redfin pickerel & 173 & 1.570 \\
\hline 2006 & SR & 5 & redfin pickerel & 174 & 1.287 \\
\hline 2006 & SR & 5 & redfin pickerel & 176 & 1.952 \\
\hline 2006 & SR & 5 & redfin pickerel & 180 & 2.377 \\
\hline 2006 & SR & 5 & redfin pickerel & 189 & 2.068 \\
\hline 2006 & SR & 5 & redfin pickerel & 197 & 2.595 \\
\hline 2006 & SR & 5 & redfin pickerel & 201 & 2.712 \\
\hline 2006 & SR & 5 & redfin pickerel & 202 & 3.466 \\
\hline 2006 & SR & 5 & redfin pickerel & 231 & 3.189 \\
\hline 2006 & SR & 5 & spotted sunfish & 61 & 0.957 \\
\hline 2006 & SR & 5 & spotted sunfish & 62 & 0.652 \\
\hline 2006 & SR & 5 & spotted sunfish & 63 & 0.835 \\
\hline 2006 & SR & 5 & spotted sunfish & 68 & 0.523 \\
\hline 2006 & SR & 5 & spotted sunfish & 81 & 0.939 \\
\hline 2006 & SR & 5 & spotted sunfish & 89 & 1.299 \\
\hline 2006 & SR & 5 & spotted sunfish & 89 & 0.746 \\
\hline 2006 & SR & 5 & spotted sunfish & 94 & 1.202 \\
\hline 2006 & SR & 5 & spotted sunfish & 95 & 0.833 \\
\hline 2006 & SR & 5 & spotted sunfish & 107 & 0.715 \\
\hline 2006 & SR & 5 & spotted sunfish & 110 & 1.204 \\
\hline 2006 & SR & 5 & spotted sunfish & 110 & 1.389 \\
\hline 2006 & SR & 5 & spotted sunfish & 116 & 0.640 \\
\hline 2006 & SR & 5 & spotted sunfish & 117 & 0.799 \\
\hline 2006 & SR & 5 & spotted sunfish & 137 & 0.922 \\
\hline
\end{tabular}

